MAESTRÍA EN ESTÉTICA Y TEORÍA DE LAS ARTES

FACULTAD DE BELLAS ARTES / UNIVERSIDAD NACIONAL DE LA PLATA

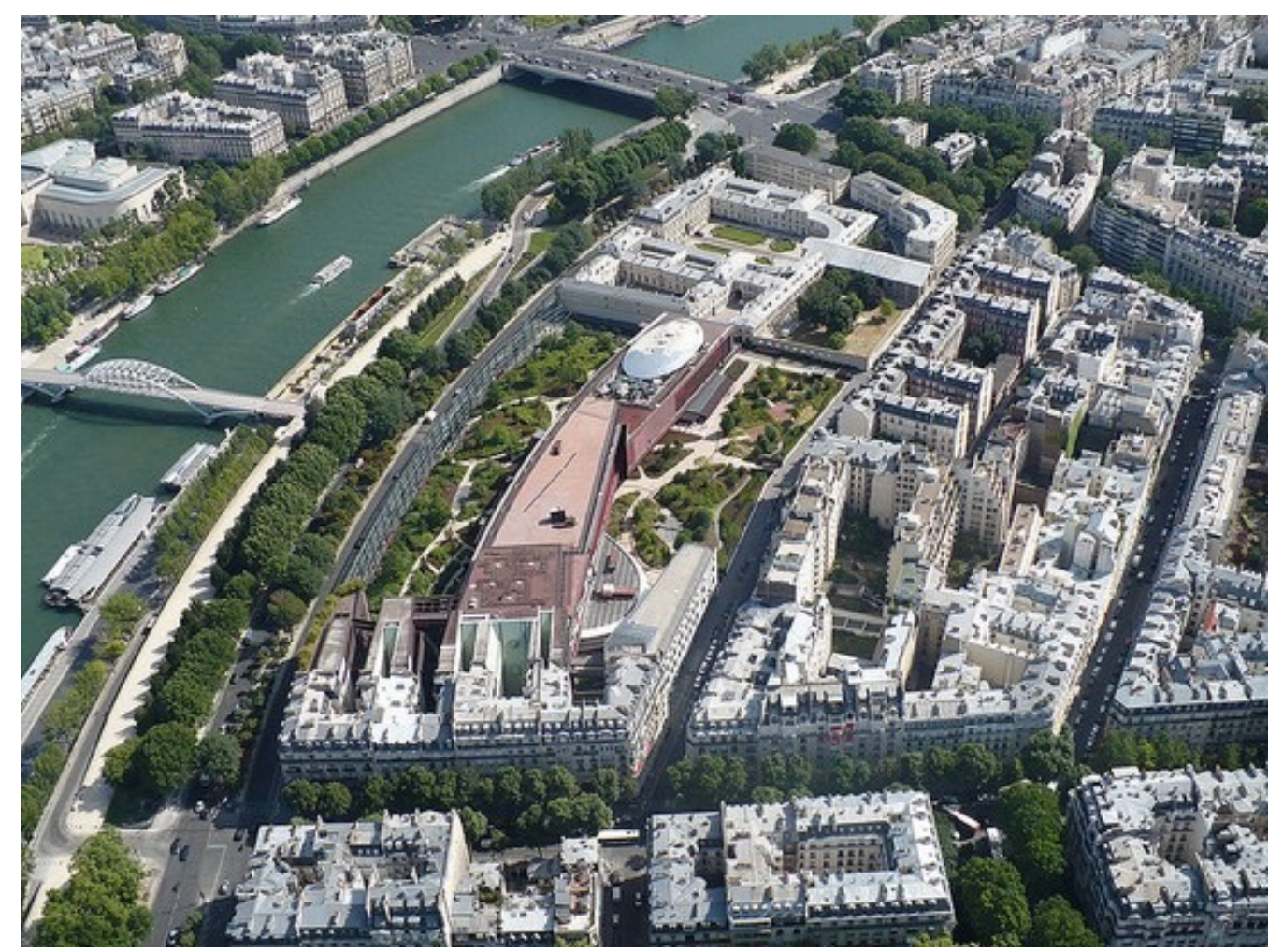

TRABAJO FINAL DE TESIS

CARLOS JONES / La Plata / 2017

Correo electrónico:

arq.jones@gmail.com

Director:

Arq. JORGE S. MELE (FADU/UBA)

Co-director:

Lic. GUSTAVO RADICE (FBA/UNLP)

\title{
DIÁLOGOS CON LA LUZ
}

LA ESTÉTICA DE LA LUZ EN EL MUSEO DEL MUELLE BRANLY 


\section{INDICE}

RESUMEN

HIPÓTESIS

PRESENTACIÓN

LOCALIZACIÓN

JUSTIFICACIÓN

METODOLOGÍA

ESTADO DE LA CUESTIÓN

OBJETIVOS Y TAREAS

I. PASADO Y PRESENTE

I.I. La Prehistoria

I.II. El periodo Románico

I.III. El periodo Gótico

I.IV. El Renacimiento

I.V. El periodo Barroco

I.VI. El Romanticismo

I.VII. La era Moderna 
II. EL COLOR: LUZ Y OSCURIDAD

III. TRANSPARENCIA Y REFLEXIÓN

IV. TIEMPO, EMOCIÓN Y RECUERDO

\section{SOMBRAS}

VI. CONCLUSIÓN

VII. REFERENCIAS BIBLIOGRÁFICAS

VII.I. GENERALES

VII.II. ESPECÍFICAS

106

VII.III. METODOLÓGICAS 


\section{RESUMEN}

Se podrían escribir miles de libros sobre la luz. Pero yo no quiero más que, una vez más, reivindicar este valor de la luz como material primero y principal con el que trabajamos los arquitectos. Y que se nos concede gratuitamente cada día. Para permanecer en la memoria y en el corazón de la gente. Para hacerles felices con la arquitectura. ¿Y cuál es la magia de la Arquitectura sino este poner en prodigiosa relación al hombre y al espacio a través de la Luz?

Campo Baeza , Alberto. www.revistadiagonal.com/entrevistes/la-luz-es-el-tema/ campo-baeza

En este trabajo he buscado comprender el comportamiento de la luz en la arquitectura, tomando como eje de análisis el Museo del Muelle Branly, obra del arquitecto francés Jean Nouvel, ubicado a orillas del río Sena en París.

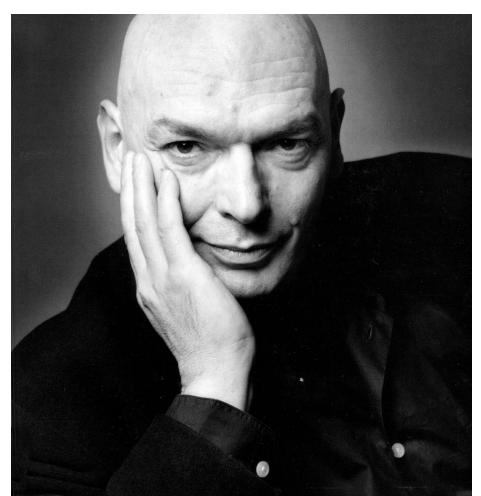


En este comienzo surgen las siguientes preguntas:

¿Hay una estética de la luz? Y en ese caso ¿Cómo opera la luz como experiencia estética? ¿La luz define un espaciotemporal? O sea, ¿define formas y transformaciones en el tiempo?.

Siguiendo este camino, más adelante analizo y describo los efectos que la luz produce sobre el espacio, los objetos que allí se exponen y especialmente sobre la sensibilidad del espectador.

Este análisis se basó en la observación directa a través de material fotográfico y fílmico, sobre registros planimétricos (plantas, cortes. alzadas), tridimensionales (bocetos realizados in situ) y en la experimentación de los fenómenos producidos por la luz en el espacio interior de la obra y en el entorno mediato e inmediato donde se encuentra ubicada en el mes de julio del año 2015. 


\section{HIPÓTESIS}

Si en la experiencia contemporánea lo estético constituye una referencia especialmente significativa, y considerando que en ella los aspectos estéticos tienen un enorme valor sensible, único y fundamental, es que nuestras experiencias interiores del mundo exterior significan que lo estético se vive como la práctica más valiosa y auténtica de incorporar el arte a nuestras vidas.

La luz, como recurso presente en toda la arquitectura, requiere de un estudio particular y profundo en la concepción de la obra para que ésta pueda expresar todo su significado. La luz hace posible su existencia como objeto formal, se hace presente en el espacio y en el tiempo, muestra su potencial cromático y hace posible la magia cuando impacta en las superficies de los diversos materiales que componen la arquitectura. De acuerdo a esto:

\section{Considero que la estética de la luz en el diseño del Museo del Muelle Branly es un recurso}

imprescindible que utiliza Jean Nouvel, sin el cual la obra no transmitiría a los visitantes los efectos que el tema requiere y que haber soslayado este recurso hubiera impactado en la pérdida del valor simbólico presente en el uso de los elementos que conforman esta pieza arquitectónica. 


\section{PRESENTACIÓN}

El museo del muelle Branly, que abrió el 23 de junio de 2006 en la orilla izquierda del río Sena en París, representa la culminación de un ambicioso proyecto perseguido por casi un siglo.

Desde Mollien a Breton, Malraux, Lévi-Strauss, y Kerchache, numerosos aficionados y expertos prestaron su ayuda a la campaña para la creación de un importante museo nacional en Francia que albergue obras de arte de las culturas indígenas de Asia, África, Oceanía y de las Américas. Esta importante y universal herencia consta de un extraordinario y diverso rango de objetos desde esculturas y utensilios recolectados por exploradores occidentales, misioneros cristianos y etnólogos y artesanías hechas para el comercio turístico. Estas destacables artesanías han encontrado ahora un adecuado lugar.

El Museo del Muelle Branly se concretó por orden del presidente Jacques Chirac. La fuerza conductora detrás del proyecto fue principalmente Jacques Kerchache, un destacado coleccionista y embajador del arte étnico hasta su muerte en 2001. En 1990 Kerchache escribió un manifiesto titulado "Las obras maestras del mundo nacen libres e iguales", publicado en los medios con la firma de 300 artistas, escritores, filósofos, antropólogos e 
historiadores de arte. El manifiesto sirvió para la creación de un departamento dedicado al arte africano, americano, de Oceanía y de la India subcontinental en el Louvre.

De esta manera, Kerchache buscó ponerle fin a la exclusión de las obras de arte étnicas de las colecciones de los principales museos de Francia.

Doce meses después de su elección a la presidencia de Francia en 1995, Jacques Chirac confirmó su apoyo al proyecto de Kerchache anunciando la creación de un gran museo que albergue las colecciones del Museo Nacional de Artes de África y Oceanía (MAAO) y del Centro para la Investigación Etnológica en el Museo del Hombre que en total sumaban unos 300.000 objetos.

Las colecciones del Museo del Hombre (alrededor de 250.000 objetos) fueron curados por académicos etnólogos y antropólogos del departamento especializado patrocinado por el Museo Nacional de Historia Natural. La exhibición y el estudio de las obras de arte se concentraron primero en sus contextos socio-culturales en los cuales fueron creados. Por otro lado, los curadores e historiadores de arte en el MAAO, se focalizaron en las cualidades estéticas de los 250.000 objetos.

Contenidos en un edificio construido para la Exhibición Colonial de 1931 en el este de París en el límite del Bois de Vincennes, el museo fue fundado en 1960 por el Ministro de Cultura, André Malraux. 
El anuncio de la creación del nuevo museo dedicado al arte tribal disparó un inmediato y encendido debate. Los curadores del Louvre fueron en su totalidad reacios a admitir obras de arte "indígenas" en sus sagrados panteones de belleza, mientras que los profesionales del Museo del Hombre fueron igualmente reacios a renunciar al control de sus colecciones, temiendo que el significativo cuerpo de investigación antropológica y etnológica se debilitaría en el contexto de un sincero museo de arte el cual exhibiría esos objetos sin explicarlos.

Estas objeciones puestas de relieve en varios ámbitos, agregaron mayor credibilidad al proyecto de construcción de un edificio que albergue las colecciones.

El 29 de julio de 1998, el gobierno del Primer Ministro Lionel Jospin aprobó un sitio a orillas del Sena en París, en el VII distrito, en el 29-55 del muelle Branly, uno de los últimos e importantes espacios vacíos. Bajo el control conjunto del Ministerio Francés de Cultura y Comunicación y el Ministerio de Escuelas, Educación Superior e Investigación, la misión de esta innovadora institución cultural sería conservar y exhibir las colecciones de arte étnico y tribal y promover la investigación y la docencia en sus respectivos campos.

Diciembre de 1998 presenció la creación del Ente Público del Museo del Muelle Branly, el cuerpo responsable de la conducción para la construcción e instalación del nuevo museo.

Stéphane Martin fue nombrada en el Directorio con Jacques Friedmann como presidente del Consejo Directivo. La tarea inmediata fue el nombramiento del arquitecto asesor del proyecto y la definición del modus operandi del futuro museo. El proyecto involucraba la creación de un nuevo y radical hecho arquitectónico en términos espaciales y funcionales. 
A principios de 1999 fue anunciado un concurso internacional y en diciembre del mismo año fue premiado el proyecto del arquitecto francés Jean Nouvel. La construcción comenzó en 2001 y tomó cinco años en completarse.

El Ente Público del Museo del Muelle Branly nombró a 18 miembros para la constitución del jurado que evaluó a 110 competidores. El jurado estaba integrado por artistas, curadores y arquitectos.

Inicialmente, el jurado seleccionó 15 trabajos que respetaban el cumplimiento de las especificaciones de las bases del concurso, la relación del edificio con el sitio, los aspectos funcionales de la idea propuesta y las consideraciones financieras, tales como la eficacia del costo del proyecto, la credibilidad del costo estimado por los proyectistas y el pago requerido por ellos.

De la lista de 14 arquitectos finalistas, el arquitecto holandés Rem Koolhaas se retiró del concurso antes de la etapa final. Los tres primeros premios fueron establecidos en el siguiente orden: Jean Nouvel, Felice Fanuele asociado con Peter Eisenmann y Renzo Piano.El diseño de Jean Nouvel fue premiado por el jurado por la gran originalidad del paisaje y los jardines propuestos, la inteligente relación con el entorno urbano, la respuesta funcional a los requerimientos del programa y su poderosa y sorprendente arquitectura. El jurado también premió el proyecto de Nouvel por la diversidad de espacios, las convenientes plantas abiertas y por la adecuada iluminación que contribuye a destacar la sofisticación de las colecciones y de las culturas representadas.

El Museo del Muelle Branly es la tercera mayor institución cultural diseñada por Jean Nouvel en la capital de Francia después del Instituto del Mundo Árabe en 1987 (también en el borde del Sena) y la Fundación Cartier en 1994. 


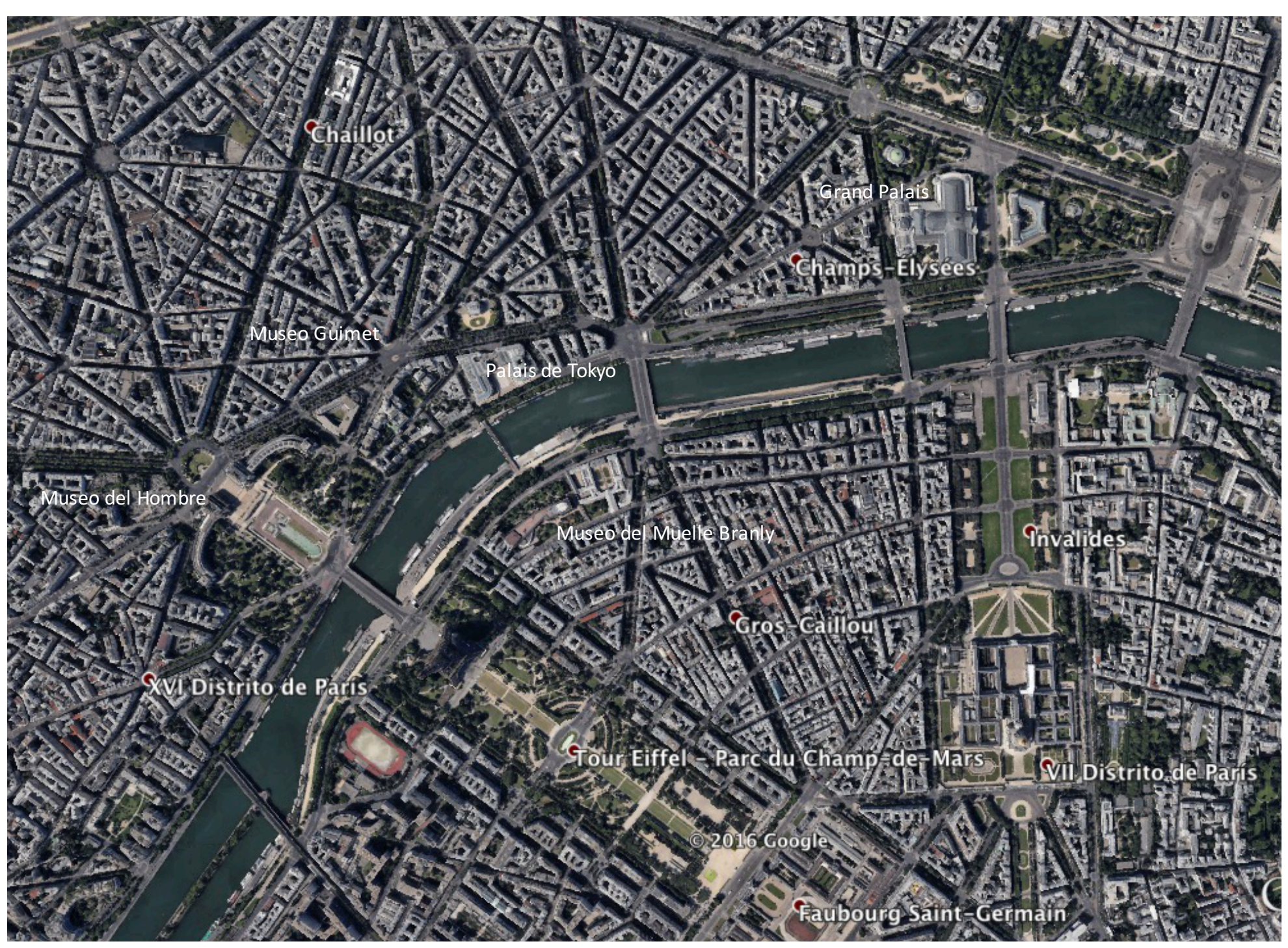


Como una destacada figura de la arquitectura internacional, Nouvel es famoso tanto por su rigor intelectual, por su compromiso con un concepto socialmente responsable y por proyectar una gran e innovadora arquitectura. Cada nuevo proyecto de Nouvel surge como un juego de fuerzas entre lo técnico y lo artístico.

Nacido en 1945 en Fumel, en el departamento de Lot-et-Garonne, la aptitud de Jean Nouvel para las artes se hizo evidente en sus primeros años. Terminó sus estudios como el primero de su clase en la Escuela Nacional Superior de Bellas Artes en París en 1966 y comenzó una carrera en la arquitectura como asistente de Claude Parent y el visionario planificador urbano Paul Virilio. En 1970, se estableció por su cuenta junto a Francois Seigneur. Once años después, a los 36 años, ganó el concurso del Instituto del Mundo Árabe, enseguida lo siguió el encargo para la renovación de la Ópera de Lyon (1986-1993), el Centro Internacional de Conferencias en la ciudad de Loire en Tours (1990), los Tribunales de la ciudad de Nantes (2000) y el Parque de Poble Nou en Barcelona (2001), todos ellos llevan la marca de su gran arte y creatividad.

En 2005, Nouvel escribió un manifiesto que coincide con una retrospectiva de su trabajo para Louisiana en Dinamarca, abogando por un concepto de "arquitectura específica" el cual contemplaría el espíritu del lugar y la geografía en llamativa oposición a la prevaleciente tendencia de formas genéricas, insulsas y homogéneas. 


\section{LOCALIZACIÓN}

En el corazón del distrito de los museos de París, cerca del Palais de Tokyo y del Grand Palais, adyacente al Museo Guimet, y a poca distancia desde el Louvre, el Museo del Muelle Branly ocupa un terreno de dos hectáreas en la margen izquierda del Sena. El lugar le era familiar a Jean Nouvel ya que anteriormente había trabajado para el concurso de un Centro Internacional de Conferencias en el mismo sitio, aunque el mismo fue eventualmente abandonado debido a la oposición de los residentes locales.

El diseño de Nouvel para el primer proyecto proponía un importante edificio público con una inmensa terraza extendiéndose hacia el Sena, bastante diferente al diseño del Museo del Muelle Branly con su complejo de edificios escondidos dentro de la "selva" diseñada especialmente para protegerlos de la vista.

A la sombra de la Torre Eiffel, entre la Rue de 1’Université hacia el sur y el Muelle Branly al norte, el museo está perfectamente integrado con su entorno urbano gracias al diseño que evita cualquier forma de impacto negativo en el entorno inmediato. La silueta curva del edificio central sigue el arco natural del río Sena, mientras que el jardín fue concebido como una extensión del vecino Campo de Marte.

Los tres edificios que albergan la administración del museo fueron diseñados para extender la media manzana de los departamentos Hausmannianos. De acuerdo a la opinión de los residentes locales, el edificio aparece como una estructura baja dentro de los edificios de los alrededores. 


\section{JUSTIFICACIÓN}

La pregunta acerca de la comprensión de las transformaciones que los museos y espacios expositivos fueron experimentando junto con el cambio artístico y social, es la cuestión que motiva mi primer pensamiento acerca de la evolución de dichos ámbitos y de cómo se están desarrollando estos procesos en el momento actual, focalizando la cuestión en el manejo de la luz que se pone de manifiesto en recurrentes ejemplos de la arquitectura contemporánea.

Del recipiente que fue el museo en sus inicios, en el siglo XX evolucionó hacia el volumen neutro en el cual la flexibilidad y las altas prestaciones tecnológicas del espacio interior facilitaron la resolución de todos los problemas y mutaciones de unas colecciones en crecimiento y de unos criterios arquitectónicos y museográficos en transformación dando como resultado unos espacios, formas y colores que dialogan bajo la luz con la obra de arte, con el objeto rescatado de su cotidianeidad, con la historia, con la gente y con su memoria colectiva.

Con respecto a los criterios estéticos involucrados en la arquitectura contemporánea, esta tarea de investigación encuentra su fundamento en las palabras de Ignasi de Solá-Morales (1995), cuando dice “...lo estético constituye, en la experiencia contemporánea, una referencia especialmente significativa" y más adelante, "En la experiencia contemporánea, lo estético tiene sobre todo el valor de un paradigma. A través de lo estético se reconoce el modelo de nuestras experiencias más ricas, más vivas, más verdaderas en relación con una realidad de perfiles borrosos" (Diferencias. Topografía de la arquitectura contemporánea. Editorial Gustavo Gili. 1995. Pg.68). 


\section{METODOLOGÍA}

Esta investigación está concebida desde lo interpretativo, lo semiótico y lo fenomenológico. Digo

fenomenológico entendido no como método deductivo sino fundamentalmente descriptivo y como doctrina universal de las esencias (eidos), es decir, es ésta una investigación concebida desde la evidencia pura, desde la esencia de los objetos, es lo que Husserl llama "intuición eidética" o "intuición de esencias" (Wesensschau). Considero que de esta manera llegaríamos finalmente a conocer la unidad objetiva de sentido, o sea, la esencia. Se trata de ver las cosas en su forma de apreciación inmediata, sin mediaciones previas. Es la experiencia directa donde la intuición capta la forma originaria, es el estado de suspensión del juicio, el concepto de "reducción" planteado por Husserl (1913).

La conciencia del objeto "Museo" se constituye en una "subjetividad transcendental", o sea, es reconocida como un fenómeno externo. Es la conciencia que va más allá de si misma y alcanza las cosas externas, momento donde debe producirse una "correspondencia" entre el objeto y el acto de conocer puesto de manifiesto en la "intencionalidad" hacia la cosa motivo de mi conocimiento. Pero como veremos más adelante, esta experimentación no se da de una vez, se experimenta desde distintos ángulos, desde distintas perspectivas y esta experiencia, por el contrario, se da en la conciencia en su totalidad, plenamente, donde todo está ya contenido. 
Debo aclarar que la intuición puesta en juego como toma de conciencia de lo observado es una compleja actividad intelectual que nos permite experimentar objetos concretos, como es el caso del Museo Branly, sino también abstractos y universales que complementan el entendimiento en la experiencia consciente del mundo.

Esta decisión surge de la particularidad de la obra y de la experiencia directa en el ámbito de la misma desde mi primer contacto, en el año 2012, cuando se despertó en mi la curiosidad de entender algo muy comentado y discutido entre los arquitectos.

Estando el edificio en una ubicación central en una ciudad como París, donde la edificación en su gran mayoría está constituida por masas compactas de alturas uniformes que van conformando las manzanas y donde la linea de frente es continua, pesada y con escasas perforaciones en comparación con la masa muraria. Esta morfología típicamente Haussmanniana tan discutida y comentada que me inquietaba, era saber por qué el edificio del museo aparecía varios metros más atrás de la linea de edificación y más aún por qué aparecía un bosque anterior a él. No era el edificio el protagonista? Qué contradicción era ésta que interrumpía la continuidad de la edificación existente en el tejido de París? Fue en el verano europeo del año 2015 que pude conocer la obra en su totalidad, es decir, desde sus espacios exteriores hasta su gran galería interior en un "viaje a través del tiempo y del espacio" hacia lugares lejanos y desconocidos, transportado por un simbolismo exuberante y un despliegue de efectos escenográficos y arquitectónicos que significaron un enorme placer para mis sentidos. 
Magia, prestidigitación, simbolismo, color, oscuridad, penumbra, realidad, virtualidad, simulación... No concibo explicar la obra y todo lo que ofrece de otra manera. Considero que esta "magia" requiere, en cierta manera, de un lenguaje que refleje la sensibilidad manifiesta en la obra arquitectónica y aquí sin más, solo trato de acercarme al encanto de esas palabras tan profundas "como la piel", a decir de Paul Valèry.

Y en las palabras de un científico:

La posibilidad de ser contemporáneos de esta expansión científica y tecnológica nos vuelve privilegiados en la historia de la humanidad. Pero los seres humanos seguimos siendo básicamente seres emocionales. Son las emociones las que predominantemente guían nuestra conducta, influyen en las decisiones e, incluso, en nuestros recuerdos. Sabemos que aunque la tecnología evolucione notablemente, es incapaz de vivencias, pasiones, sentimientos íntimos, empatía, como lo hace nuestro cerebro. Por todo esto, es imprescindible saber que estas tecnologías ultramodernas deben estar al servicio de las personas y las comunidades y no al revés. Los seres humanos somos mucho más que hardware y software: somos nuestra experiencia que modula las conexiones neurales y nuestra genética, somos nuestras pasiones, nuestras frustraciones, nuestros sueños y nuestra esperanza, nuestro talento y nuestro sacrificio para imaginar un futuro mejor y alcanzarlo.

Manes, Facundo. "Cómo será el cerebro del futuro".

Parte del artículo publicado en el Suplemento Especial del

diario Clarín (9 de diciembre de 2016). 


\section{ESTADO DE LA CUESTIÓN}

Si bien en los años sesenta Theodor Adorno había asociado con bastante acierto el término Museo con el de Mausoleo $^{1}$, las transformaciones experimentadas en los últimos años del siglo XX y en los transitados en el presente siglo, muestran una destacable evolución en el diseño gracias a nuevas ideas acompañadas por unas reveladoras tecnologías que han permitido novedosas maneras de abordar la materialización de estos ámbitos. Según la distinción que establece Marshall McLuhan entre medios fríos y medios calientes en cuanto a la información que ofrecen, y la mayor o menor participación o interacción del público con los objetos expuestos, podríamos decir que de acuerdo a esto, los nuevos museos muestran un marcado desarrollo hacia los primeros, es decir, que al ser éstos los que transmiten menor información, incluyen al observador haciendo que éste tenga que interpretar según sus propios significados y de esta forma lograr su activa participación.

\footnotetext{
${ }^{1}$ Monumento funerario levantado sobre la tumba de una persona, generalmente de una persona importante: Girardon es autor del mausoleo de Richelieu, compuesto con serena perfección. ETIMOLOGÍA Préstamo (s. xvii) del latín Mausoleum y este del griego Mausolêion, derivado de Máusolos, nombre de un rey de Caria a quien su esposa hizo construir un monumental sepulcro.
} 
La contemplación fría no tiene como objetivo producir un juicio estético o una elección; es simplemente la repetición permanente del gesto de mirar, cierta conciencia de la falta de tiempo necesario para emitir un juicio consistente basado en una contemplación minuciosa.

Groys, Boris. Volverse público. Las transformaciones del arte en el ágora contemporánea. Caja Negra Editora. 2014. Pg.99.

Se logra, entonces, en la contemplación de un medio frío una unidad absoluta entre el observador y lo observado lo que nos indica que lo uno no tendría sentido sin lo otro, es decir, el medio frío incluye al observador. En lo relativo al tratamiento de la luz que los actuales museos están evidenciando, es de destacar no solo la forma de iluminar las obras allí expuestas. Actualmente, el diseño de estos edificios contempla otras cuestiones muy unidas al concepto total del edificio.

Así como los más destacados museos contemporáneos incorporan en su diseño un alto valor simbólico tanto en su tratamiento exterior como interior, la luz no es sino un elemento utilizado para contribuir a la exaltación de ciertos valores simbólicos que la obra busca representar.

Como señala Dufrenne en su "Fenomenología de la experiencia estética" (1953): "la contemplación estética es el acto social por esencia".

El recorrido por el espacio de la obra, provoca la emoción y la reflexión del visitante. El público es 
transportado a una dimensión ajena al entorno urbano al que pertenece donde la luz es un elemento relevante en esta experiencia. Quiero destacar aquí lo que la obra provoca en el sentimiento del observador y para esto referirme sin más a la definición que nos da el Diccionario con respecto a la palabra emoción: -"sentimiento muy intenso de alegría o tristeza producido por un hecho, una idea, un recuerdo...”, -“alteración del ánimo producido por un sentimiento de alegría o tristeza".

Son estas alteraciones del individuo las que representan modos de adaptación a ciertos estímulos y que considero ilustra fehacientemente lo que sucede en el observador inmerso en este tipo de espacios. Es que sin emoción no hay recuerdo, no hay memoria.

Lo que reconozco a través del análisis de la obra es la idea gestáltica de la luz como figura (elemento central) y fondo (elemento del contexto), la luz como producto y proceso a la vez donde el espectador y la luz co-construyen los diversos significados de las partes del edificio y los objetos que ellas albergan y la luz como material estético, lo que implica ahondar en los fenómenos que ella provoca, como el COLOR, la TRANSPARENCIA y la

\section{REFLEXIÓN, el TIEMPO y las SOMBRAS.}

Es necesario, entonces, definir los términos ESTÉTICA y LUZ como factor primordial en el análisis de la obra en cuestión: 
... la estética no es la teoría de lo bello o del arte, no es tampoco la teoría de la sensibilidad. Estética es un concepto históricamente determinado que designa un régimen específico de visibilidad y de inteligibilidad del arte, que se inscribe en una reconfiguración de las categorías de la experiencia sensible y de su interpretación. Es ese nuevo tipo de experiencia lo que Kant sistematizó en la Crítica del juicio. La experiencia estética implica una cierta desconexión de las condiciones habituales de la experiencia sensible. Lo que Kant resumió en una doble negación. El objeto de aprehensión estético se caracteriza porque no es ni un objeto de conocimiento ni un objeto de deseo. La apreciación estética de una forma es una apreciación sin concepto. No está en función del saber según el cual un artista dio forma a una materia dada.

Rancière, Jaques. Pensar entre las disciplinas: una estética del conocimiento. https://desarquivo.org/sites/default/files/ ranciere_disciplinas_268.pdf. (2008)

La Estética es la rama teórica del estudio del arte. En virtud de ello, se ocupa de cuestiones fundamentales como la naturaleza del arte, el valor artístico y la percepción artística dentro del campo general de la experiencia perceptiva. La Estética estudia la percepción y la sensación. La teoría de la experiencia visual, es asunto de la Estética.

Mitchell, W.J.T.. Mostrando el ver: una critica de la cultura visual. www.estudiosvisuales.net/revista/pdf/num1/mitchell.pdf.(2003) 
... el significado originario del término "estética": para los griegos la aísthesis designaba la capacidad de tener conocimiento por medio de los sentidos. Ambas maneras de entender la estética, o sea, como filosofía del arte y como percepción sensible, serán tenidas en cuenta en este análisis estético de la luz.

Por otra parte, material estético es todo aquello que el artista utiliza para realizar su obra. En este sentido, se podrá hablar de la luz como material estético al ser ella empleada en la construcción de una imagen visual. Pero el material estético rara vez es utilizado en forma bruta y directa; el material estético recibe por parte del artista algún tipo de tratamiento o manipulación con la finalidad de transformarlo deviniendo lo que se requiere de él. Si se considera la luz como material en bruto, habrá que denominar de otro modo el resultado de la luz tratada o manipulada. El término "iluminación" podría ser empleado entonces para designar el tratamiento de la luz. Si la luz es la materia prima sin elaborar, la iluminación será la obra terminada, luz tratada. Los términos "luz" "iluminación" serían equiparables, entonces, a los términos "pigmento" y "cuadro" en el caso del pintor, o "piedra" y "estatua" en el caso del escultor.

Rinaldi, Mauricio. ¿Qué es la estética de la luz? https:// RINALDI, +Mauricio.+“¿Qué+es+la+estética+de+la+luz\%3F”

La arquitectura es el juego magistral, perfecto y admirable de masas que se reúnen bajo la luz. Nuestros ojos están hechos para ver las formas en la luz y la luz y la sombra revelan las formas.

Le Corbusier. Hacia una arquitectura. Editorial Poseidón. (1964) 
El rasgo particular de la luz es aquel que hace visible el mundo. Sin luz no hay percepción sensible, no hay sustancia. En ausencia de la luz la realidad está presente pero es a través de ella que adquiere forma sensible para nosotros. Gracias a la luz entendemos el mundo. La luz da sentido a la objetividad del espacio y determina nuestra percepción. El tipo y calidad de la luz y las propiedades del material iluminado, definen la percepción que se pueda tener de él. Finalmente creo que las palabras de Jean Nouvel resumen el estado actual de las ideas a través de las cuales se están concibiendo los nuevos espacios expositivos:

"El museo de hoy en día es un lugar en el que se intenta hacer compartir sensaciones y emociones..." 


\section{OBJETIVOS}

1. Determinar las ideas e intenciones proyectuales del diseñador.

2. Describir los aspectos estéticos en el Museo del Muelle Branly, donde la luz contribuya a dar sentido a la percepción de los espacios presentes en esta obra.

3. Identificar los aspectos sensoriales y estéticos que la luz provoca en el espectador en su recorrido por el exterior y el interior de la obra.

4. Reconocer diferencias y semejanzas en el diseño del museo con los espacios a que hace referencia desde la configuración material del hecho arquitectónico.

5. Describir la materialidad en lo que hace a su definición exterior. La envolvente del edificio en sus paramentos verticales y sus implicancias en el manejo de la iluminación interior y sus resultados estéticos.

6. Profundizar en los aspectos sensoriales y estéticos en el tratamiento de la luz.

7. Indagar sobre otros aspectos que derivan del uso de la luz en la obra de referencia.

\section{TAREAS}

1. Analizar bibliografía general sobre aspectos sensoriales referidos a la percepción en ámbitos de la Arquitectura.

2. Analizar bibliografía particular referida a toda obra de arquitectura donde la luz desempeñe un papel central en la configuración del espacio y en el recorrido a través de éste (espacio-tiempo).

3. Analizar el material recogido in situ. 


\section{ı. PASADO Y PRESENTE}

Que sea la historia de la arquitectura una historia del manejo de la luz no parece ser algo alejado de la realidad de sus edificios. Es que ella ha hecho posible contrarrestar la materialidad atada a la tierra y por consiguiente ha hecho posible la elevación a las alturas del Gótico, hasta la expresión ingrávida de los conceptos de velocidad de la arquitectura contemporánea.

Si la arquitectura es posible, entre otras cosas, gracias a la luz y es por ella que adquiere un significado, posibilitando la expresión de ideas religiosas hasta las más terrenas de las necesidades del hombre, es que es preciso recorrer previamente la evolución de tan importante aspecto: el de la utilización de la luz a través de la historia de la arquitectura.

\section{I.I. La Prehistoria}

Las primeras fuentes de luz en la prehistoria, después del sol, fueron la antorcha y la hoguera. Hace 400.000 años a.C. el hombre ya encendía fuego dentro de las cavernas. El hombre había aprendido a controlar el fuego y ese fue el primer paso hacia un mundo civilizado.

Si desde épocas prehistóricas era la escasez de luz en el interior de las cuevas, en las que solamente el hombre se alumbraba con el fuego de las antorchas, en la actualidad no es esta falta precisamente la que preocupa al hombre 
sino cómo dominarla, cómo prevenirse de la inundación de luz que invade sus hábitats en épocas donde el problema energético es cada vez más apremiante.

\section{I.II. El período Románico}

El hombre medieval, y su expresión en el arte románico, vivía aquellos tiempos de oscurantismo signados por temores religiosos a los que su arte estaba básicamente dedicado. Eran épocas donde la vida era realmente penosa, de trabajo duro y escaso y nulo el tiempo del disfrute. Pensemos que la expectativa de vida era de apenas treinta años, el futuro en esta tierra no parecía nada prometedor, quizá por eso la esperanza estaba puesta en Dios y en su lugar sagrado, la iglesia. Era la esperanza de la vida después de la muerte y eran los templos los que simbolizaban ese anhelo.

Las iglesias eran de factura rústica donde su envolvente y su estructura de sostén cumplían la misma función. La luz apenas ingresaba por pequeños huecos practicados en los gruesos muros donde la austeridad y la penumbra eran lo más

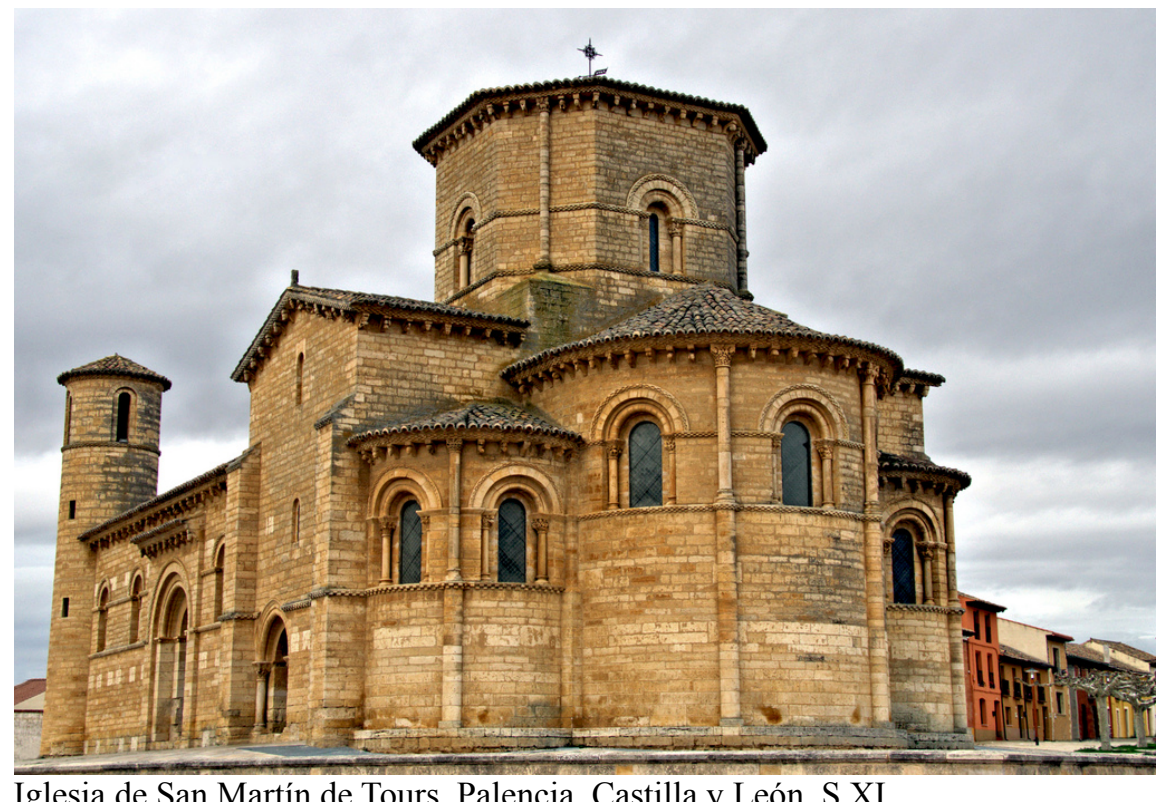


llamativo, ciertamente aspectos claves para la contemplación y la oración.

Los escasos rayos de luz ingresaban por el ábside orientado al este o sea el sol de la mañana, (era la luz divina), y desaparecían por el oeste, lo que significaba el juicio divino.

\section{I.III. El período Gótico}

El paso del Románico al Gótico propone un cambio con respecto la pesadez de los muros de piedra que soportaban las bóvedas de cañón, y da paso a una arquitectura que buscaba, con su simbolismo, la admiración del

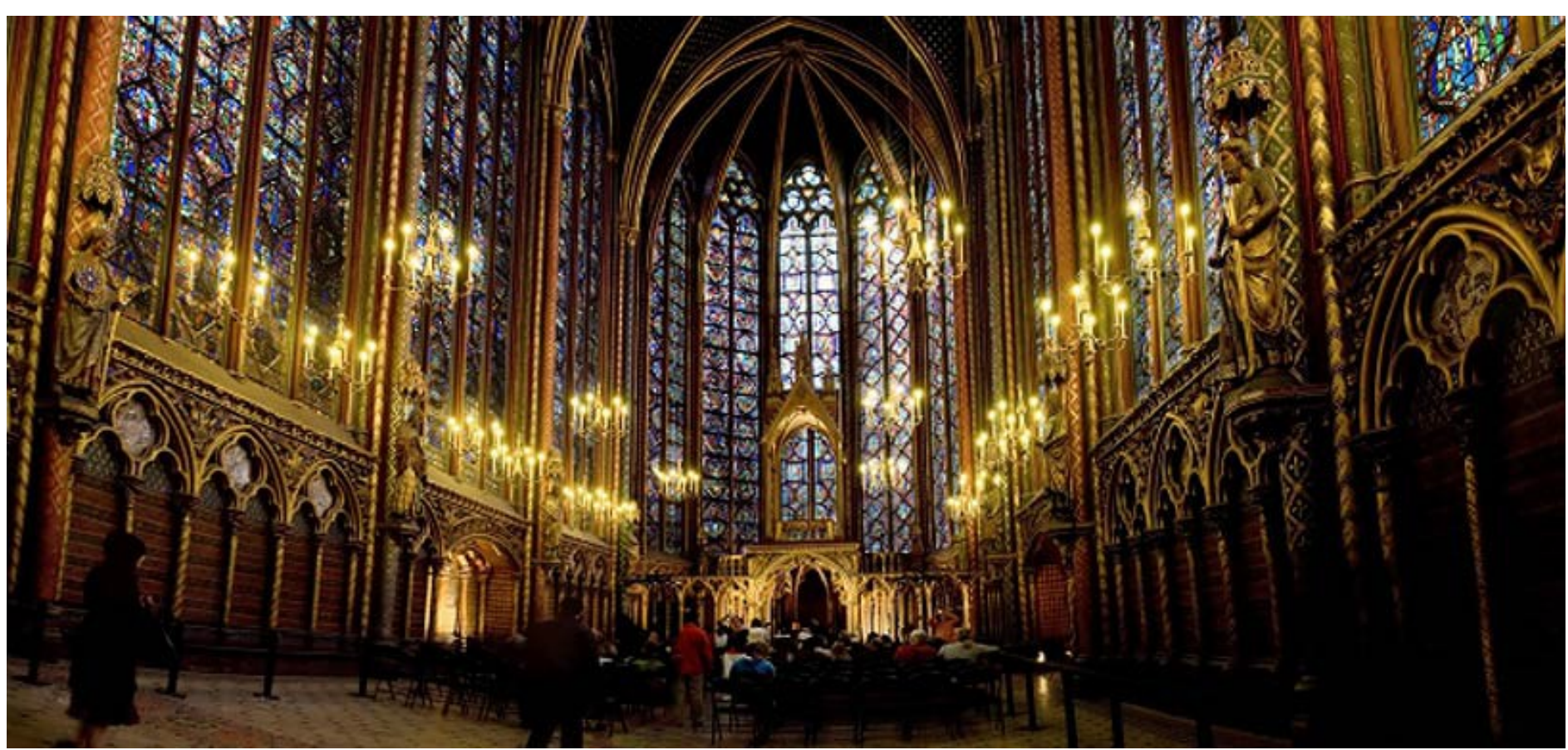

Sainte Chapelle. París. 1241. 
visitante, el encuentro con una realidad basada en el concepto teológico de la luz omnipresente de Dios a través del color de sus vidrieras para transmitir el mayor de los impactos.

La arquitectura gótica adquiría sentido en el manejo de su luz. La dispersión de ésta en los espacios de las catedrales creaba el clima escenográfico propicio para alcanzar a Dios, contemplando sus altísimos vitrales compuestos por infinidad de colores y sus maravillosas bóvedas de crucería.

Esta era la concepción religiosa de la época puesta a disposición del pueblo. Estas ideas quedaban así plasmadas en grandiosas obras de arquitectura que no eran más que el reflejo del ansia de alcanzar las alturas, la elevación del espíritu hacia los cielos.

Esta evolución técnica en la construcción de tan imponentes obras no fue solo el cambio de un estilo a otro posterior, fue simplemente que el gótico hizo de sus obras un culto a la luz. El avance que se produce en el concepto estructural hace que las cargas sean derivadas fuera de aquellos gruesos muros a través de los arbotantes. De esta manera se pudo perforar la envolvente para disponer gran cantidad de vitrales que inundaban de luz coloreada los interiores de las catedrales.

En efecto, el deleite estético proviene de que el ánimo reconoce en la materia la armonía de su propia estructura; y si esto sucede en el plano de la affectio imaginaria, en el estado más libre de la contemplación, la inteligencia puede dirigirse verdaderamente al espectáculo maravilloso del mundo y de las formas.

Eco, Umberto. Arte y belleza en la estética medieval.

2.2. Los místicos. Pg.17. 


\section{I.IV. EI Renacimiento}

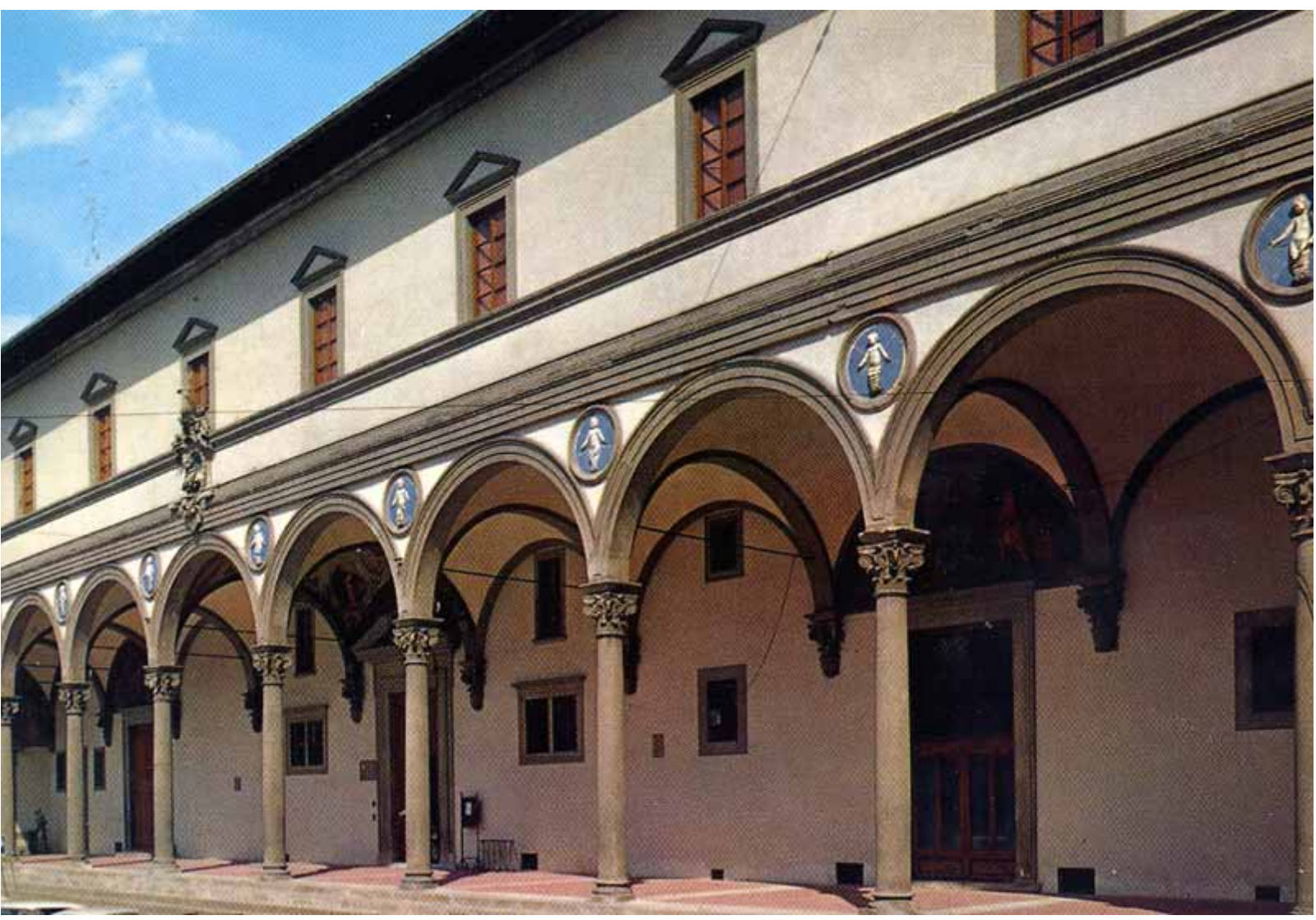

Hospital de los inocentes. Florencia. Italia. Filippo Brunelleschi. 1419.

El camino de los tiempos medievales al Renacimiento está marcado por la pérdida gradual del misticismo religioso hacia una concepción humanista donde el hombre es al que va dirigida la luz que conciben los arquitectos 
de la época. Es notable como van quedando atrás los símbolos religiosos dando paso a la visión del hombre. Es la visión hacia los cielos contra el descubrimiento de la perspectiva, la visión humana reflejada en su nueva arquitectura. Un claro ejemplo de lo anterior es el Hospital de los Inocentes en Florencia y su conocida columnata.

En los años del Renacimiento la luz juega un papel relacionado con ideal de belleza del humanismo. La luz pertenece también al hombre y éste la usa gracias a los nuevos avances de la ciencia y del arte. Es una luz homogénea y total, todo lo inunda, ya no está dirigida de manera parcial como en el Gótico, ahora envuelve los espacios habitados por el hombre. Es la belleza de la luz presente en la naturaleza lo que recupera esta época para los hombres donde el medio natural y el humano comienzan a ser uno mismo.

\section{I.V. El período Barroco}

Posteriormente, entre los años 1600 a 1750, surge el período Barroco en contraposición al arte renacentista. Este se caracteriza por su impronta formal y su carácter notablemente científico aplicado al mundo sensible. En esta nueva era, hay un despegue de los cánones establecidos para el arte a favor de la libertad de expresión y de conceptos sujetos a formas arquitectónicas más cercanas a lo teatral. Es evidente el giro hacia una nueva visión de la ciudad. Esta se va construyendo para ser observada y una nueva forma de diseño está

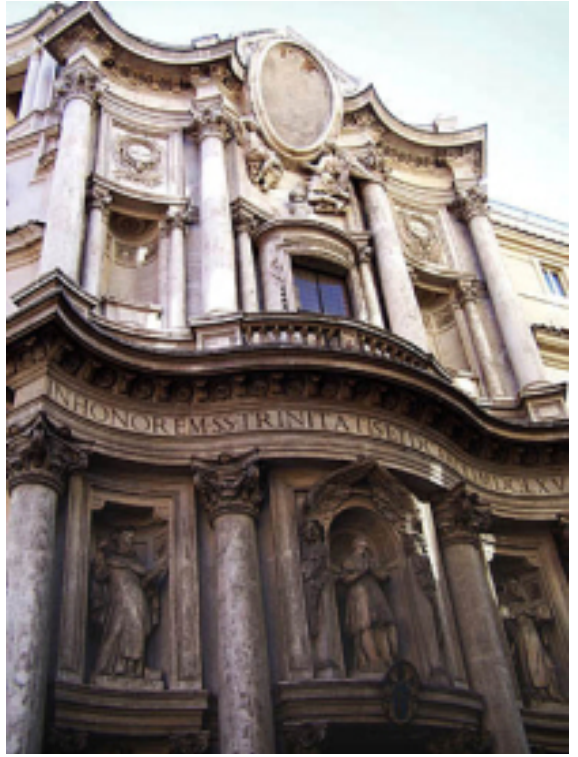


expresada en los frentes donde predomina la ondulación dada por la disposición de columnas y muros curvos. Hay una nueva conciencia del movimiento que empieza a manifestarse en las ciudades.

La luz en el Barroco está concebida para crear ambientes sorprendentes y cargados de contrastes. Lo importante es mostrar de manera realmente exagerada los claroscuros tanto en la pintura como en la arquitectura.

\section{I.VI. El Romanticismo}

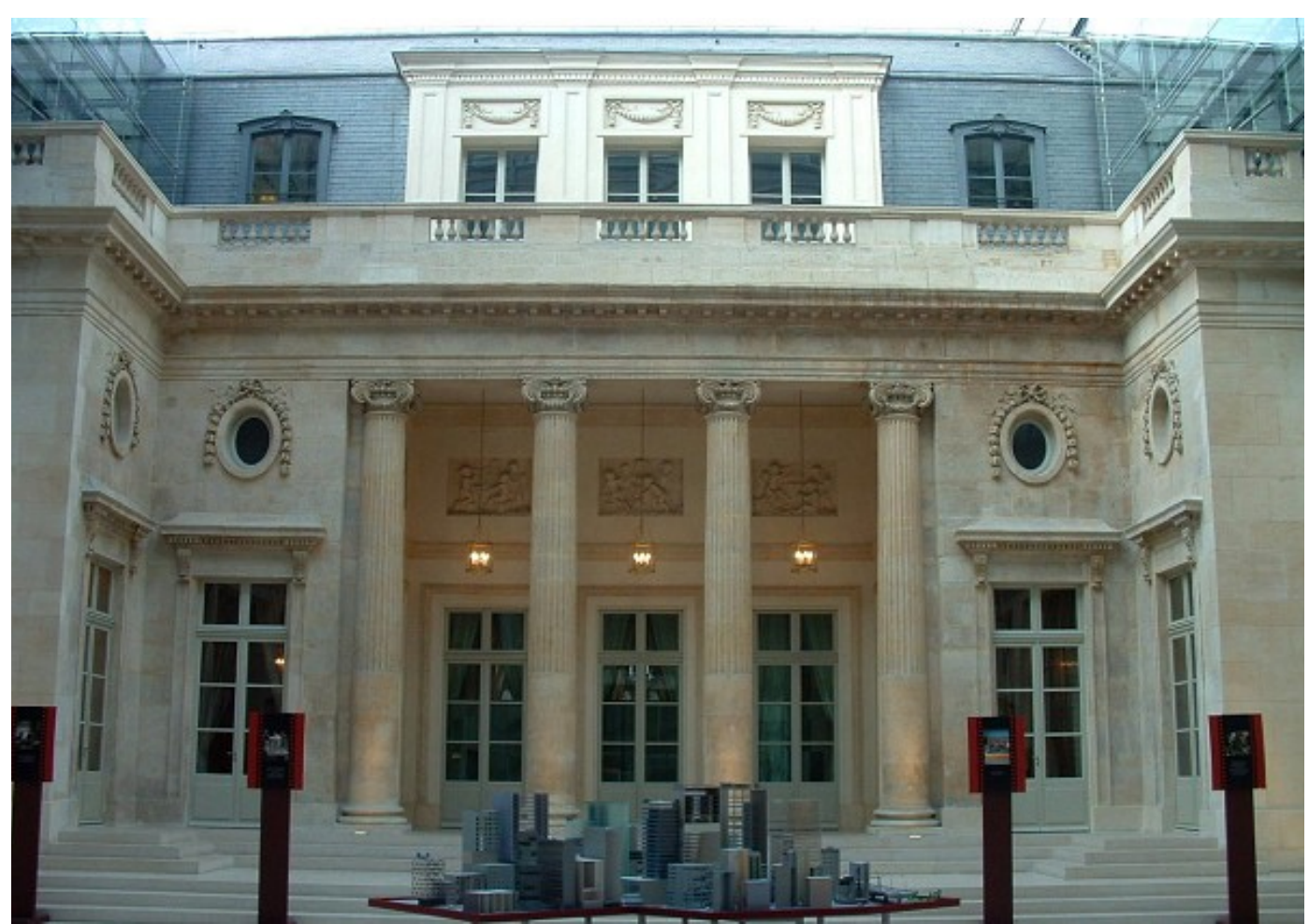

Hotel Alexandre. París. Étienne-Louis Boullée. París.1763. 
Desde 1750 a 1830 aproximadamente, se desarrolla un período que vuelve a los orígenes clásicos. En esta época se retoman las formas arquitectónicas del pasado griego y romano, floreciendo las edificaciones de corte netamente monumental. En lo relativo al uso de la luz, en este periodo se prefiere una distribución uniforme, es decir, no hay interés en particular por dirigirla hacia ningún objeto o espacio determinado. Predomina la simetría en las composiciones arquitectónicas así como las lineas rectas se imponen sobre los arcos y las curvas de las fachadas del periodo Barroco. Es destacable la exaltación que se hace de lo relativo a lo sensible donde lo onírico desempeña un papel destacable en ciertas arquitecturas como es el caso de tres arquitectos de este periodo: Boulée, Ledoux y Lequeu. En ellos hay un uso muy especial de la luz. Hay en sus obras efectos muy fuertes de luz y sombras, los efectos dramáticos en sus obras son característicos de la búsqueda de unos ambientes, quizá, adelantados a la época en la que ellos desarrollan sus obras. En definitiva, los sentimientos se imponen a la razón y ellos se manifiestan en las obras del período romántico.

\section{I.VII. La era Moderna}

En la arquitectura moderna se ofrece la capacidad de opción entre la oscuridad de los orígenes y el descubrimiento, a principios de siglo, de la luminosidad total. Desde el deseo de búsqueda de luz hasta la desbordante fastuosidad de la posesión absoluta de la misma y el consiguiente problema de cómo dominarla. 
En lo relativo al tratamiento de la luz que los actuales museos están evidenciando, es de destacar no sólo la forma de iluminar las obras allí expuestas. Actualmente, el diseño de estos edificios contempla otras cuestiones muy unidas al concepto total del edificio.

Así como los más destacados museos contemporáneos incorporan en su diseño un evidente valor simbólico tanto en su tratamiento exterior como en su diseño interior, la luz y el color, entre tantas otras cosas, son elementos utilizados para destacar cierto simbolismo que la obra necesita ofrecer al espectador.

De esta manera en el museo del muelle Branly el "clima", tanto exterior como interior tiene que ver con el uso que hace el diseñador tanto de la luz natural como así también de la luz artificial. La "selva" por donde se ingresa es la antesala de la "cueva” interior. La luz allí es filtrada por entre la abundante vegetación. Nos llega suave y sin deslumbramiento, por así decirlo, es un baño de semioscuridad.

La luz evoca dónde estamos, adónde pertenecemos en ese momento. Posteriormente "la cueva", lugar interior, oscuro, nos transporta a otra dimensión. Una dimensión un tanto extraña, inquietante, donde las formas y los objetos tienen una presencia un tanto fantasmal. Todo esto, puesto en escena por la luz.

El museo del muelle Branly no posee iluminación cenital. La luz penetra tamizada por su envolvente lateral. El plano superior, conteniendo la iluminación puntual artificial es "el cielo nocturno con estrellas" visto desde la selva (Fig.1). 


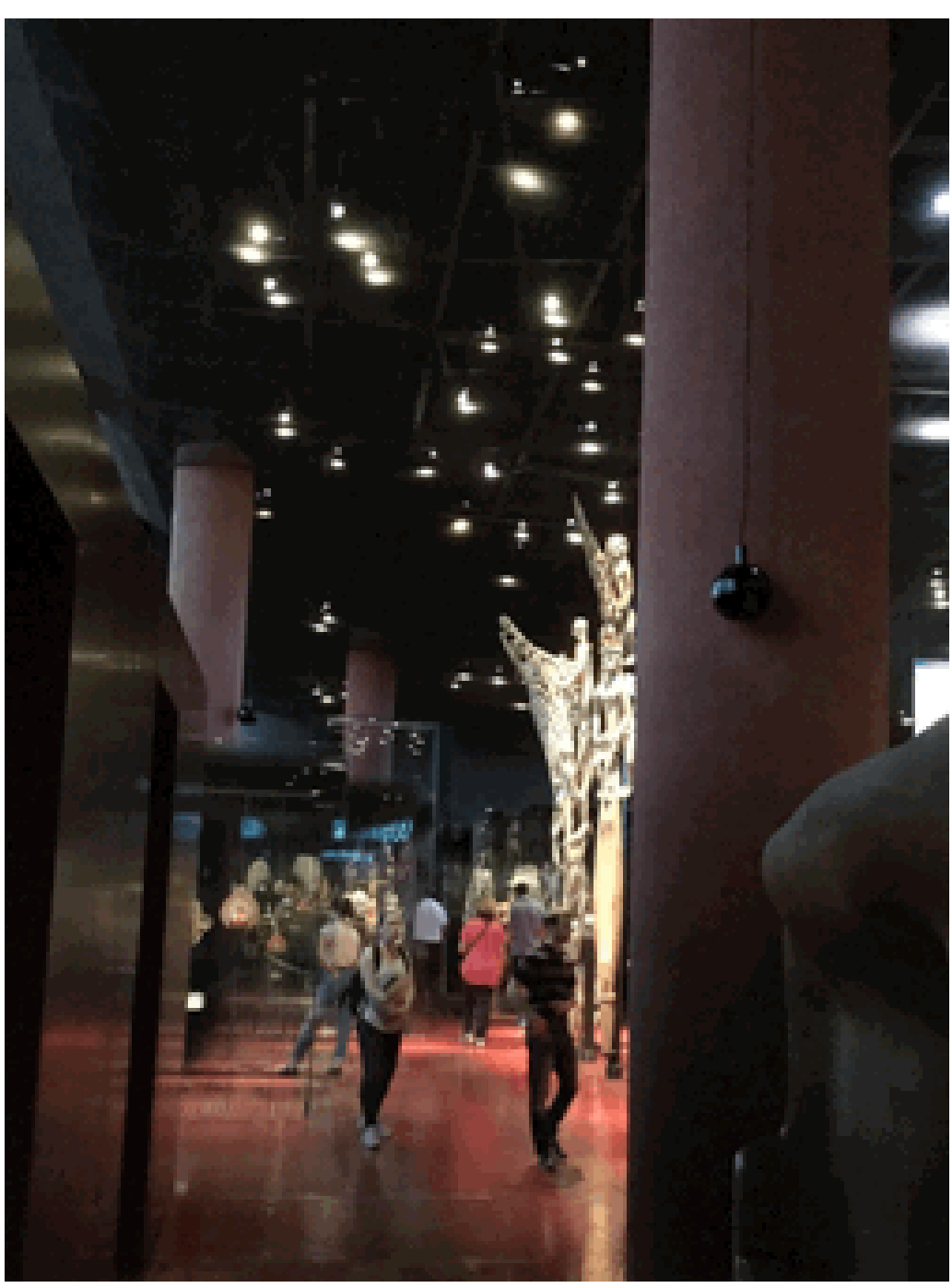

(Fig.1) Vista del cielorraso con la iluminación artificial.
Es la luz exterior y la luz interior, son dos dimensiones. Un adentro y un afuera solo tomando sentido en la frontera de los acontecimientos, en la superficie, en la piel del edificio. Es aquí donde podemos traer a la memoria la frase de Gilles Deleuze (1994): "Paul Valery tuvo una frase profunda: lo más profundo es la piel" ("La lógica del sentido". Segunda serie de paradojas. De los efectos de superficie. Pg.33).

Así, los efectos de superficie tratados por los estoicos, son retomados por Lewis Carroll en su obra “Al otro lado del espejo" donde los acontecimientos ya no son buscados en las profundidades sino en la superficie, es el rechazo a la falsa profundidad, es darse cuenta que todo ocurre en la frontera. Es por el hecho de transitar por la superficie que se pasará del otro lado, ya que el otro lado no es sino el sentido inverso. 
"Continuum", la obra de la artista italiana Cinzia

Campolese, representa la

dualidad en el espacio. Sin embargo, ese

desdoblamiento

termina configurando una continuidad dentro de éste. (Fig.2)

En esta instalación, la luz es una presencia

primordial en el espacio.

Los rayos de luz tocan y

atraviesan el panel vidriado

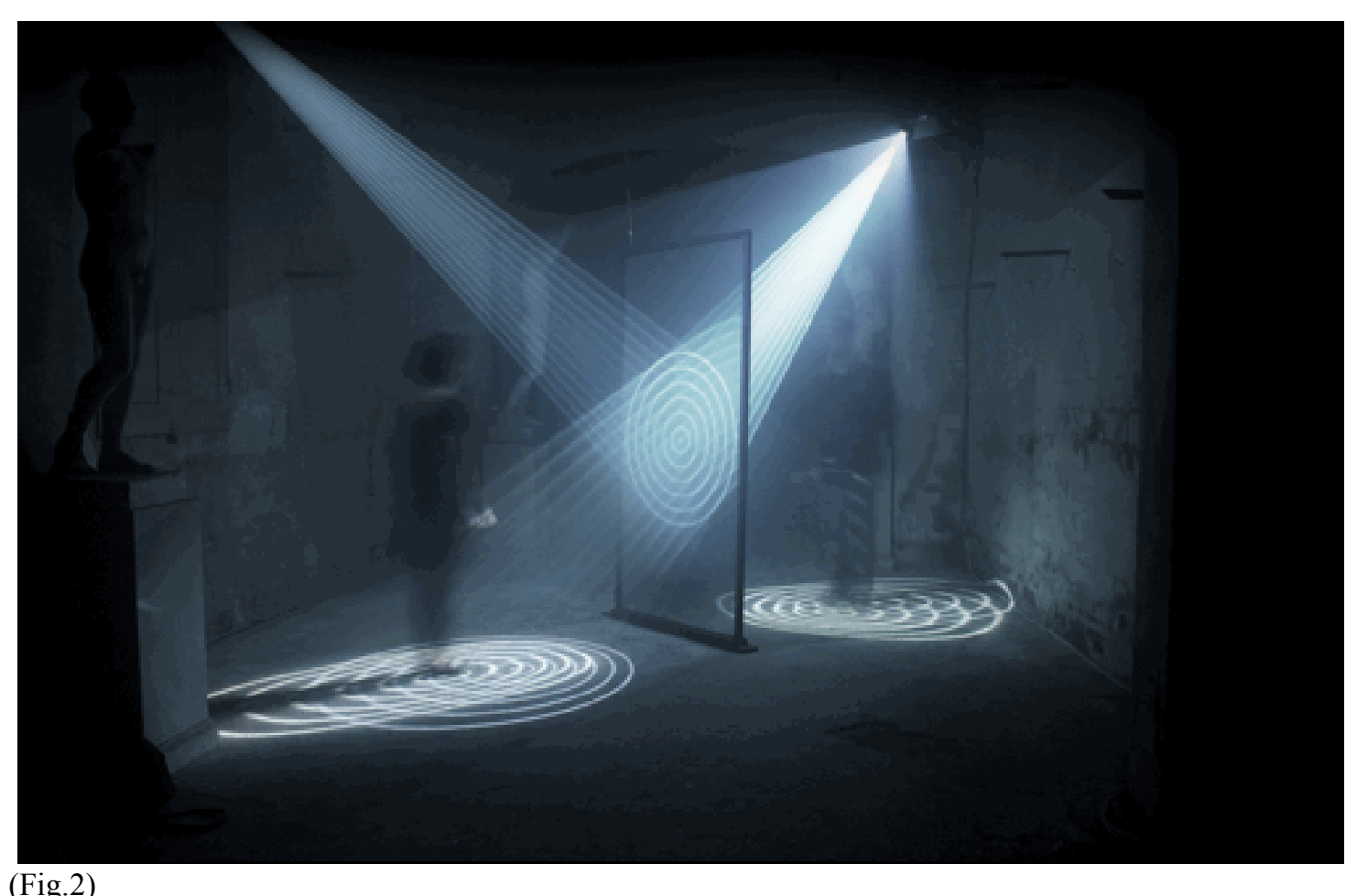

dando como resultado imágenes opuestas y continuas.

El Museo del Muelle Branly es un tributo al genio creativo de las culturas de África, Oceanía, Asia y las Américas. Es la antítesis del cerrado y contenido complejo arquitectónico tradicional. Como un refugio diseñado para preservar y proteger objetos de aquellas culturas, el edificio mismo es receptivo, abierto y adaptable -la materialización arquitectónica de su filosofía subyacente de tolerancia e intercambio cultural-. 
El edificio que incorpora cuatro niveles y una terraza panorámica y ofrece vistas sobre París y el Sena, ha sido diseñado por Jean Nouvel como un "lugar de misterio" que custodia los objetos allí guardados. Dentro de una estructura polimorfa muy alejada de los cánones occidentales y conceptos tradicionales de la arquitectura y el diseño de museos, los visitantes exploran novedosos espacios diseñados para permitir que cada obra pueda ser apreciada en su totalidad en espacios que conservan el espíritu de las culturas a las cuales el edificio está dedicado.

El complejo consta de cuatro edificios que cuentan en total unos 30.000 metros cuadrados: el Branly y Auvent, el museo mismo y el edificio a lo largo de la Rue de l'Université. Cada uno está concebido como una unidad arquitectónica específica, con sus necesidades funcionales particulares.

El museo del Muelle Branly está concebido como un puente sobre pilotes. El edificio parece asomarse como una pasarela a diez metros de altura sobre un gran paisaje verde que se extiende desde el muelle Branly hacia la Rue de 1'Université. Aquí, Jean Nouvel ha proyectado un edificio extendido entre dos grandes cilindros de hormigón armado a este y oeste flanqueando una extendida galería soportada por 26 columnas metálicas. Estas columnas distribuidas al azar recuerdan un bosque fundiéndose con los árboles de los jardines a su alrededor.

Los materiales utilizados para los pisos, los cielorrasos, los exhibidores y otros elementos del mobiliario juegan un papel esencial para brindarle vida e identidad al edificio. 
Para Jean Nouvel, el trabajo en madera y las instalaciones fueron la más importante etapa en el proceso de construcción. En el Museo del Muelle Branly, Nouvel ha creado un vocabulario "específico"

deliberadamente apartado de las formas y tradiciones occidentales. El interior del museo evita el uso de materiales manufacturados y ostentosos (como el mármol). No hay galerías rectilíneas ni exhibidores de vidrio que obstruyan la vista de los objetos. El museo intenta mostrar sus colecciones tan directa y naturalmente como sea posible en un lugar apropiado con espacios que permitan expresar y apreciar el potencial carácter emotivo en toda su dimensión.

La etapa final de la obra se focalizó en los aspectos más exigentes de la visión de Nouvel hacia los detalles. La organización del museo y el espacio interior están diseñados para dar la impresión de estar en un entorno natural. La madera es el material predominante, usado en los soportes cruzados de los ventanales de la fachada norte, o en los parasoles plegados que le proyectan sombra a la galería principal. Las paredes y especialmente los pilares, están revestidos con un revoque rugoso color ocre. Algunas de las superficies están decoradas con diseños que se asemejan a tatuajes.

En la galería principal, los objetos están contenidos dentro de 300 exhibidores concebidos como formas transparentes, son envoltorios que no limitan la visión y que emergen directamente desde el piso. De la misma manera, otros elementos del interior del museo están diseñados para “desvanecerse" dentro del espacio del museo permitiendo comunicarse directamente con los objetos allí expuestos. 
Desde el foyer del museo, una sinuosa rampa de 180 metros de largo corre alrededor del cilindro que contiene la colección de reserva de instrumentos musicales. Esta rampa se asoma sobre la Galería Jardín y atraviesa el museo en dirección hacia la larga galería que contiene las colecciones permanentes.

Sigo "río arriba" (en la evocativa descripción de Jean Nouvel) en una ruta hacia la galería principal, una extensa área situada a diez metros de altura bajo la cubierta del edificio.

El sombrío espacio me conduce a un viaje alrededor del planeta: grupos de objetos organizados por zonas geográficas forman un conjunto de "mojones" dentro de los cuales los visitantes son invitados a seguir una selección de caminos temáticos. (Fig.3)

Las 3.500 obras de la colección permanente están exhibidas en un "paisaje abierto" muy alejado del expositor "formal" de los museos convencionales. En el centro del recorrido, un sinuoso camino conduce entre paneles cubiertos con escamas de cuero que

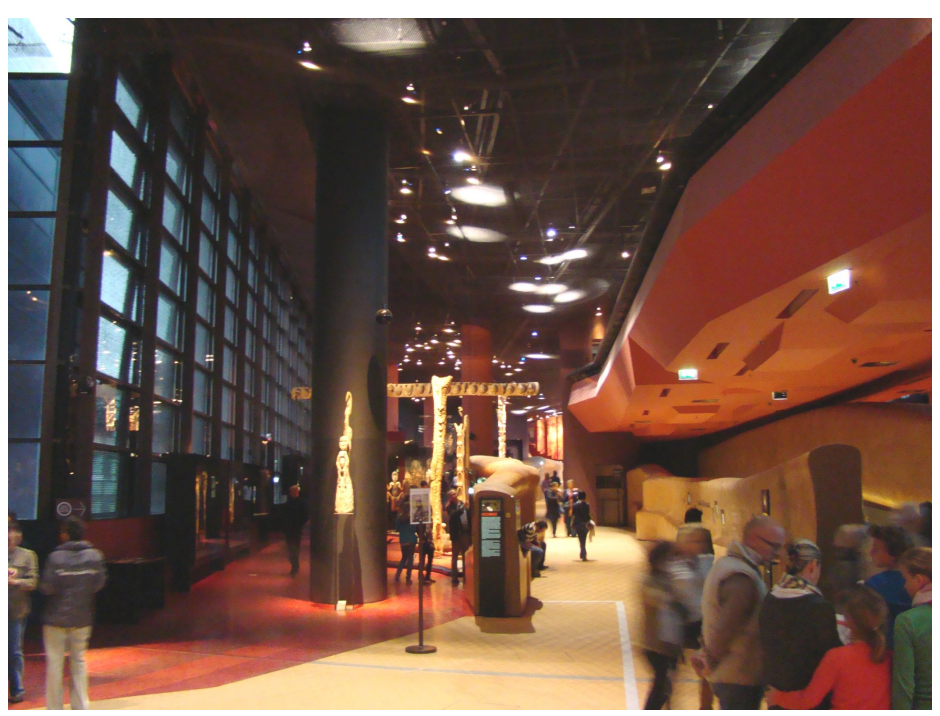

(Fig.3) La gran nave longitudinal. se asemejan a una piel de serpiente.

Los paneles presentan pantallas que transmiten imágenes, textos o videos. Además de las pantallas audiovisuales la "serpiente gigante" también presenta una variedad de instalaciones que usan luz, sonido y elementos táctiles que crean una maravillosa experiencia sensorial. (Fig.4) 


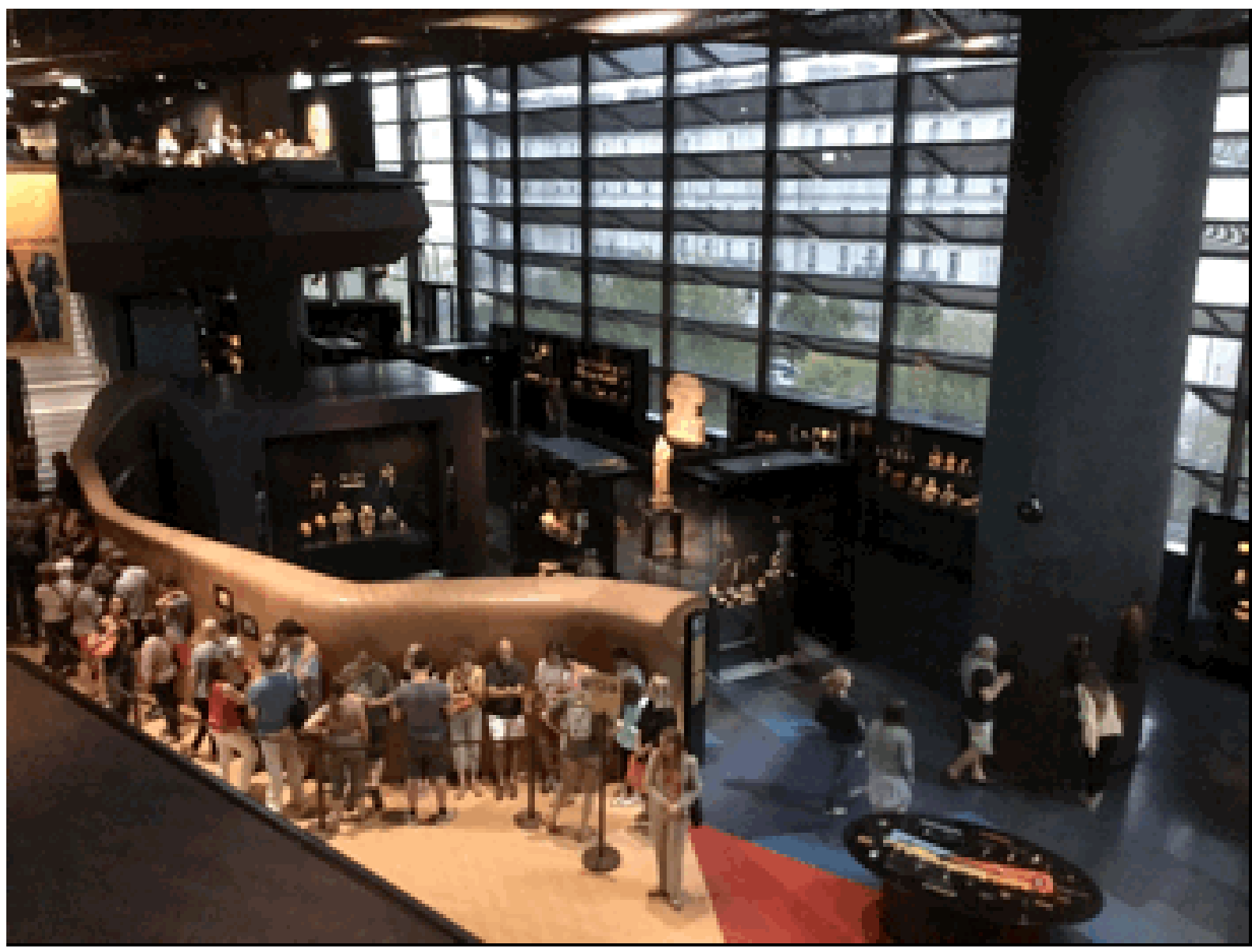

(Fig.4) Vista del objeto serpiente en el centro de la nave.

La colección permanente se completa con tres galerías "suspendidas" a manera de islotes, diseñadas para animar a los visitantes a examinar las obras expuestas desde una variedad de diferentes aproximaciones. 
La primera galería, al oeste de la galería principal, cubre unos 600 metros cuadrados y presenta un cambiante programa de exhibiciones. La segunda galería cuenta con unos 800 metros cuadrados y pone el foco en temas universales que han dado forma a la interacción entre los habitantes del mundo desde el comienzo de los tiempos: creatividad, creencias, supervivencia, iniciación, crecimiento y conquista.

La galería central presenta una introducción a los principios básicos de la investigación antropológica a través de enciclopedias multimediales. En el nivel del jardín, una galería de unos 2.000 metros cuadrados, llena de luz, aloja dos exhibiciones anuales temporarias, en primavera y otoño, presentando objetos desde el pasado al presente.

A través del estudio del museo del Muelle Branly, se advierte que la experiencia estética se co-construye en la interacción entre el visitante y los diversos espacios, texturas, colores y objetos montados en una dinámica que le aporta coherencia y valor simbólico y donde la luz es el elemento que habilita la construcción de significados individuales y culturales en la experiencia estética. En este sentido, la luz adquiere un rol protagónico dentro y fuera del museo. Más allá de emerger de la interacción entre formas, volúmenes y texturas, la luz se convierte en un elemento arquitectónico y discursivo central que opera sobre las partes mismas del edificio. Así, el diseño busca incidir en la experiencia del visitante-espectador para "navegar el río" (Fig.5) y "caminar la selva" (Fig.6), para transmitir la emoción de un viaje al tiempo y lugar en el que habitan los objetos que allí se exponen. 
Cuando la luz entra en escena se evidencia un paralelo entre los valores teatrales de la arquitectura. El dramático carácter de un rayo de luz cayendo sobre un visitante, sobre los objetos allí exhibidos o simplemente

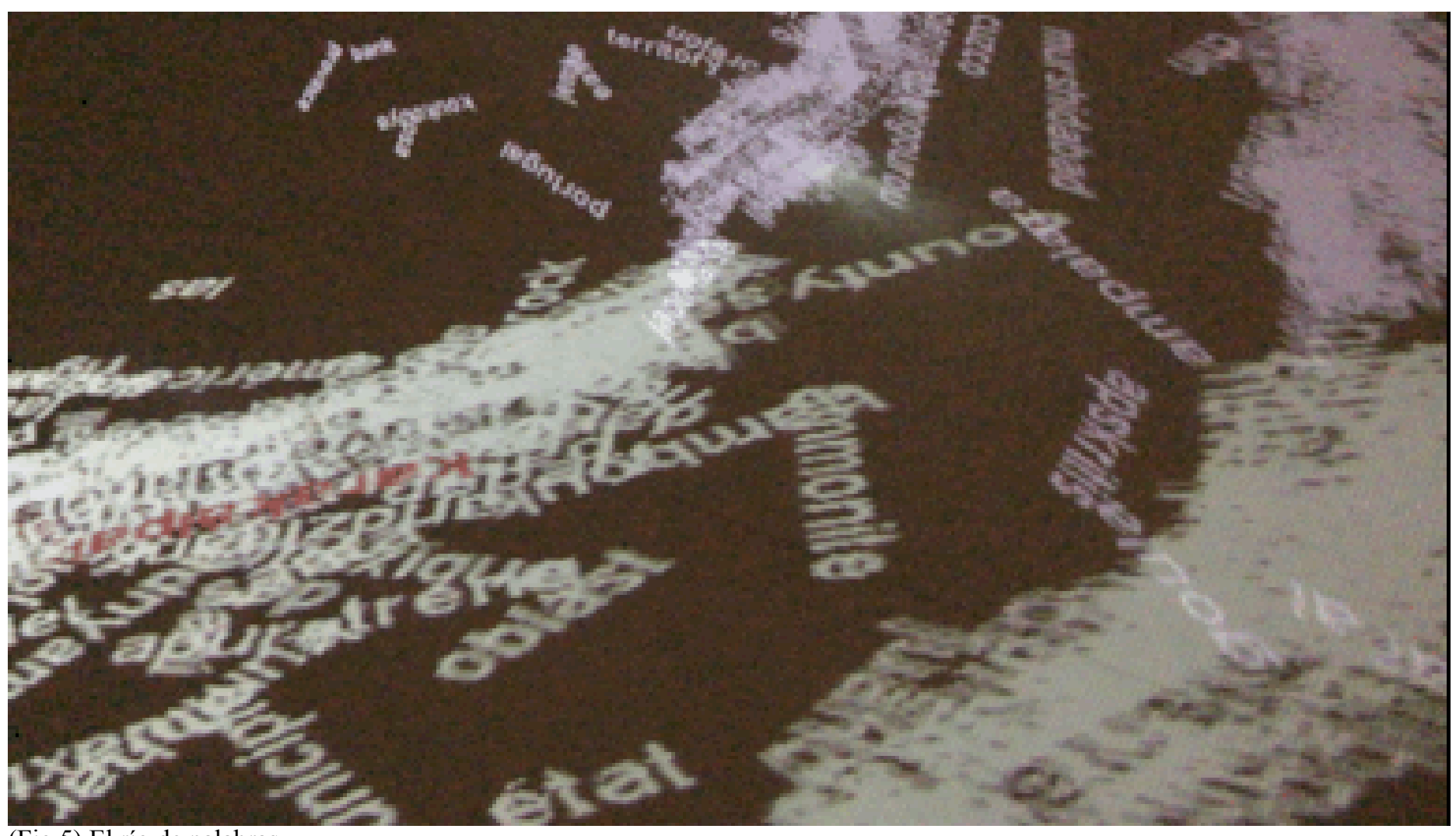

(Fig.5) El río de palabras.

atravesando el espacio mismo del museo, remite a la histórica fascinación que ejerce esta presencia por su asociación con lo más alto, con lo divino. 
Aquí está presente la recreación de escenas que inducen al espectador a creer que algo sobrenatural está ocurriendo, es el deseo manifiesto en la obra de arquitectura que se sienta la experiencia de un mundo de magia y fantasía. En nuestro caso, la luz tamizada y la penumbra crean un carácter dramático. (Fig.7)

Podría decir que la arquitectura es a menudo puesta en escena por la luz o dicho de otro modo, ésta se hace

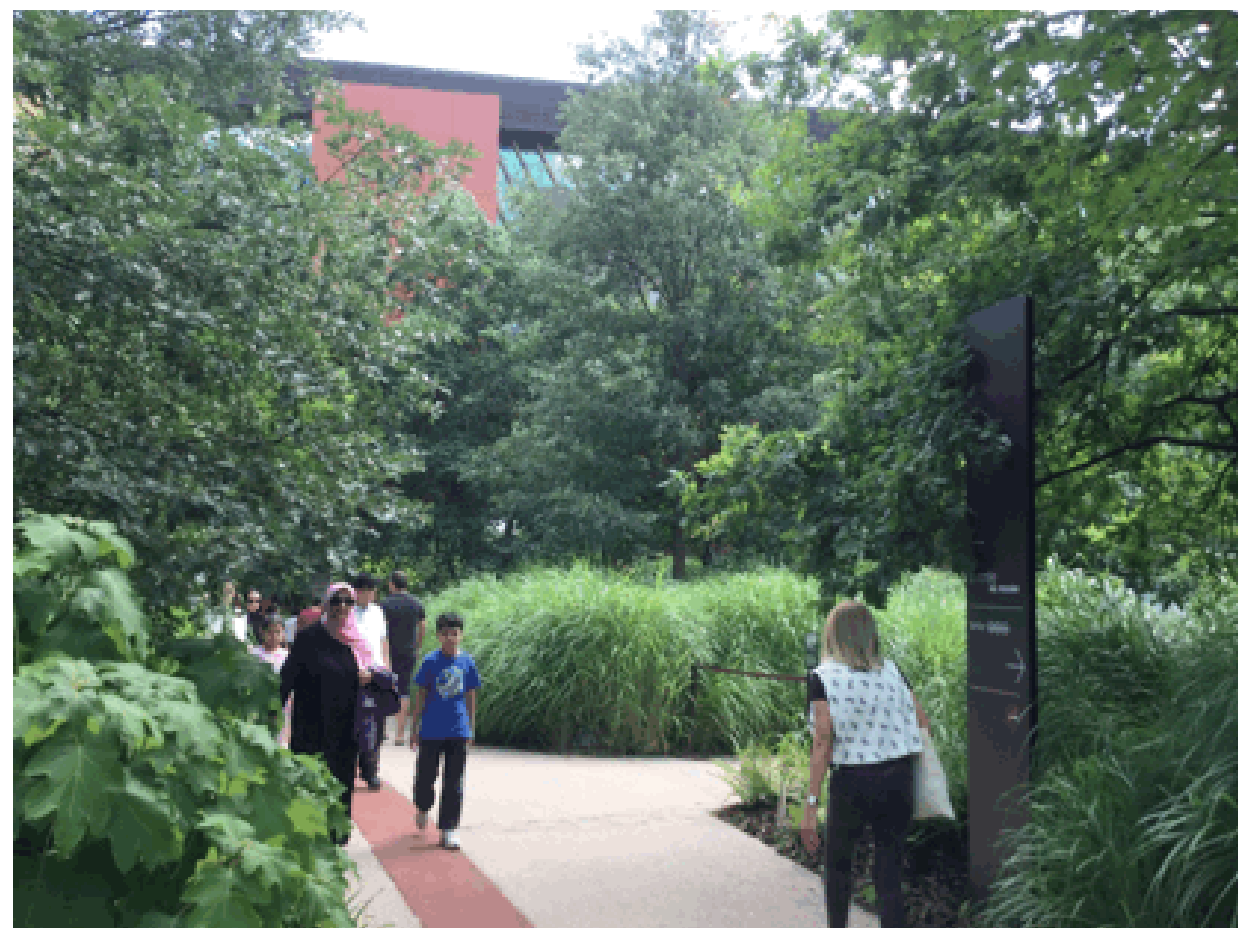

(Fig.6) Vista de la gran vegetación exterior y los senderos que la atraviesan. presente bajo la luz. Creo que estos

fenómenos no provocan la súbita emoción del espectador por el solo hecho de hacerse presentes, es necesario una mirada intencionada, sensible, aún diría impresionable y no objetiva.

Según Slavoj Zizek (1991): "Si miramos de frente, es decir, con realismo, de modo desinteresado y objetivo, sólo vemos una mancha informe; el objeto solo asume rasgos claros y distintos si lo miramos "desde un costado", es 
decir, con una mirada interesada, sostenida, impregnada y "distorsionada" por el deseo.

Objetivamente, el objeto es nada, pero, visto desde un cierto ángulo, asume la forma de algo". ("Desde la realidad a lo real" en: Mirando al sesgo. Pg.29).

Esta es la manera que nos plantea la obra allí presente y de esta forma deberá experimentarse. Observando la capacidad de modificar los espacios de la arquitectura y al darle un sentido al tiempo se puede considerar a la luz como un elemento esencial en la arquitectura.

La capacidad que tiene la luz de provocar sensaciones y estimular la percepción en el espectador haciendo vivenciar los espacios de maneras asombrosas y muchas veces inesperadas, promueve el aporte principal de este trabajo. La percepción visual necesita de la luz para hacerse 
posible. A su vez, como material estético, la luz puede construir ámbitos sorprendentes y originales lo que motiva este estudio de sus características sensoriales.

Según Louis Kahn (1980) "la materia es la luz extinguida, cuando deja de serlo, se convierte en materia. El silencio tiende a expresar algo, la luz lo crea, le da forma". ("El silencio y la luz" en Estudio Paperback. Pg.16).

La luz presente en el espacio transcurre en el tiempo. Esta acción involucra una morfología y una sintaxis, una creación de la forma en el espacio y un juego de transformaciones en el tiempo. La luz está en la pintura, en la escultura y en la arquitectura, disciplinas con un evidente grado de formalización, cuestión que sirve de modelo al estudio estético de la luz.

Siendo consciente que los dictados de la belleza han ejercido un influyente mandato a través de los siglos, podría decir, entonces, que el mejor resultado de un proyecto no depende tanto de la tecnología empleada, sino del concepto estético desarrollado. La técnica utilizada es así la consecuencia del concepto estético como ocurrió en el gótico tardío y su ejemplo más significativo: la Sainte-Chapelle en la Île de la Cité de París y la ilusión de la elevación hacia los cielos de los seres sobre la tierra gracias a los altos vitrales que conforman la envolvente de la nave superior y el paso de la luz a través de ellos. Esta investigación sobre la estética de la luz busca enfocarse desde puntos de vista filosóficos, sensoriales y arquitectónicas que evidencien el hecho artístico. En este sentido pretendo abordarlo con un sentido fenomenológico y entender la luz en la obra como un hecho estético. El camino comienza a través del planteo de preguntas para luego intentar dar respuestas. 


\section{п. EL COLOR: LUZ Y OSCURIDAD}

¿Cómo opera la luz como experiencia estética?

Si la luz es color ¿qué sensaciones provoca en el espectador?

¿Qué oculta el fenómeno detrás de su “inmaterialidad"?

Considerando ese algo oculto, se hace necesaria la definición de Heurística. Ésta proviene de la voz griega

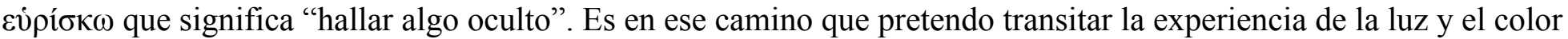
en el ejemplo que me ocupa, el camino del descubrimiento.

Algunas definiciones:

- El color es un elemento cuyo valor simbólico suele mantenerse inalterable a lo largo de los años y de las diferentes culturas.

- El color expresa el reconocimiento ligado a su propia cualidad cromática y sugiere un conjunto de valores en calidad de signo, convirtiéndose en portador de asociaciones significativas. 
- Según José Luis Caivano (2001): “El color puede ser el signo de un fenómeno físico y el signo de una sensación. También puede ser el signo de un mecanismo fisiológico o de una asociación psicológica. Como quiera que sea, en todos estos casos es un signo diferente". (Ilusiones y efectos visuales que involucran distribución espacial de la luz. Actas del Cuarto Congreso Argentino del Color. 1998).

La aplicación del color, recorre una amplia gama de funciones, desde cubrir la superficie de un objeto, hasta representar simbólicamente una idea o un concepto. Comprender integralmente la forma, la materia, la luz y el color, es necesario para la interpretación y manipulación consciente de los objetos producidos por el hombre, entre ellos, la arquitectura. Para ésta, el color tiene un significado diferente al de la pintura, su sentido es completamente distinto con respecto a la elección del color, éste determina, generalmente, el efecto espacial del edificio, aunque también crea sensaciones de quietud o de atención. Con respecto a los materiales, el color exalta o disminuye las características propias de la apariencia de los edificios. La materia, la luz y el color son de esta manera, una unidad que le otorga sentido a la forma arquitectónica.

Tratando de desentrañar el misterio del color, varios autores coinciden en poner en primer plano al observador como participante fundamental en la experiencia de este fenómeno y en ese sentido Johann Wolfgang von Göethe (1749-1832 ), a través de sus investigaciones, propuso un nuevo método basado en la identificación del objeto con el sujeto observador que tiene como base una contemplación muy cuidadosa acompañada de la intuición y la imaginación. El efecto que sobre las personas producían los colores, y que fue observado por Göethe, fue el 
comienzo de la actual psicología del color. Esta disciplina comenzó a estudiar las perturbaciones fisiológicas y psicológicas que el color provoca sobre los seres humanos.

"No podemos separar lo visto del que lo ve", decía Göethe (Teoría de los colores. 1810), con lo cual afirmaba que el color no es solamente un principio físico. Creía que éste cobraba sentido por la presencia del observador ya que son los ojos los que perciben el fenómeno.

En el transcurso de sus investigaciones, comprobó que los colores aparecen en el limite entre la luz y la oscuridad, momento en el cual destacaba que "no existe la luz sin la oscuridad". Y más tarde confirmaba que la luz

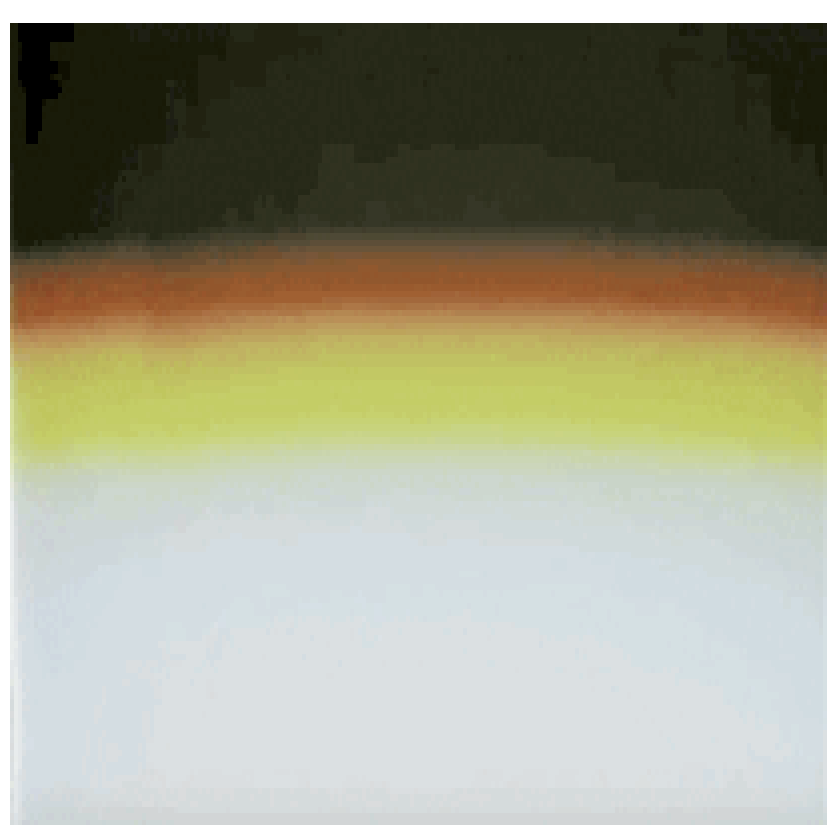

se hace visible cuando choca con la materia y que por lo tanto en si misma es invisible. (Fig.8)

Observo aquí la intencionalidad casi poética de Göethe al aseverar que vemos la oscuridad en las sombras cuando contemplamos espacios vacíos y es en este momento que con respecto a esta observación, define los siguientes pares: luzmateria y oscuridad-vacío, a lo que llama: La polaridad luzoscuridad. Podría decir entonces que materia y espacio son inseparables. 
Más tarde, en una conferencia pronunciada en Viena, Rudolf Steiner (1861-1925), decía lo siguiente en relación a las investigaciones realizadas por Göethe:

"Ahondamos más en lo que Göethe quería, analizando su Teoría del Color capítulo a capítulo, incluso ascendiendo hasta los efectos sensoriales-morales de los colores, donde hasta cierto grado, el color desaparece del campo visual y, si pudiera decirlo, aparecen las cualidades del espíritu, del alma y de la moralidad. Las experimentamos en el lugar del rojo y el azul cuando somos transportados al reino del alma. Y Göethe diría en este caso que es solamente entonces que en realidad aprendemos algo sobre la esencia del color cuando el color desaparece y aparece algo totalmente diferente".

En los años posteriores a los trabajos desarrollados por Göethe, Arthur Schopenhauer (1788-1860), hizo su propia investigación sobre los colores en un intento por diferenciarse y mejorar el trabajo de su admirado predecesor, Göethe. Schopenhauer pensaba que la percepción de los colores por el ojo humano tiene una cualidad subjetiva; lo cual iría vinculado a su conocida idea de que el mundo es nuestra representación, la de cada individuo que lo percibe.

Para Schopenhauer el color depende de la actividad del ojo del observador. Contrariamente, Göethe entiende al color como modificación de la luz. Es notable que a pesar de las diferencias en sus investigaciones, tanto

Schopenhauer como Göethe, coinciden en que los colores se encuentran entre los extremos de la luz y la oscuridad, comprobando de esta manera la particularidad del fenómeno del color. 
Paralelamente, el caso de Michel Eugène Chevreul (1786-1889), químico de profesión, coincide en considerar al color como una sensación, apreciación ésta un tanto sorprendente al pensar que su tarea profesional estaba relacionada con la ciencia y los productos textiles.

A través de sus investigaciones, Chevreul llegó a la conclusión que los aspectos fisiológicos son determinantes en la comprensión e interpretación del color.

Considerando una visión cultural, Norwood Russell Hanson (1924-1967) señala que la observación está cargada de teoría y Fernando Tudela fundamenta su teoría en que la observación parece consistir en la asimilación por parte de un sujeto de una realidad que no viene totalmente impuesta por el objeto, sino que es al menos en parte, producto de una organización operada por el sujeto.

Para culminar este breve repaso histórico de las visiones acerca del color y sus implicancias sensibles, Gastón Breyer (1919-2009) en su presentación al Cuarto Congreso Argentino del Color (1998), considera que quizá una explicación antropológica señale que el color es como un valor agregado a la forma visual, un producto de la evolución de la especie y alega que dos cuestiones se podrían afirmar: Que los colores no los inventó el hombre y que no se pueden definir, lo que equivale a decir que el color es un hecho inefable, inhablable.

Si lo analizamos desde el punto de vista morfológico, podría decir que el color es inseparable de la forma, entendiendo que ninguna forma es posible sin color, aunque el color y la forma transcurran por caminos separados. 
La relación forma/color, se puede establecer entre dos circunstancias opuestas y todas sus variaciones intermedias.

Es el caso del color coincidiendo o reforzando la estructuración de la forma y el del color y la forma como hechos antagónicos (por ejemplo el camuflaje), aunque como regla general diría en palabras de un arquitecto:

La elección del color no puede estar gobernada por reglas si ha de ser un acto vivo de creatividad. Al fin y al cabo, tales reglas son el producto de la contemplación de las obras de arte.

La única prueba del valor de un efecto cromático o de una obra de arte en general es que nos proporcione un placer continuado.

Rietveld, Gerrit. (Extracto de la conferencia reproducida por la Revista 2G, números 39/40)

Específicamente en el caso que me ocupa, la percepción del color es el primer frente visto aproximándome a lo largo del muelle Branly, es el de los árboles plantados sobre el lado norte del jardín. La obra maestra central de todo el complejo, los jardines, están diseñados para proteger la estructura del museo como una envoltura de resguardo natural de las obras en su interior. La "selva" por donde se ingresa es el primer acercamiento a la "cueva" interior. La luz allí es colada por entre el verde de la vegetación.

El museo, en vez de quedar circunscrito a un reducto geométrico, aparece ya por todas partes como una dimensión más de la vida. Así, la etnología, en vez de 
circunscribirse a su papel de ciencia objetiva, va en adelante a generalizarse, liberada de su objeto, a todas las cosas vivas y va también a hacerse invisible, como una cuarta dimensión omnipresente, la dimensión del simulacro.

Jean Baudrillard. Cultura y simulacro. Pg.9. Editorial Kairos.

Barcelona. 1978.

El jardín, diseñado por el arquitecto paisajista Gilles Clément, es destacable por su tamaño y forma, incorporando árboles, planos ondulantes y áreas silvestres. Áreas de césped y líneas rectas han sido evitadas para permitir la proliferación de la hierba alta y un diseño informal de senderos sinuosos. (Fig.9)

El jardín presenta una vegetación exuberante a los lados de los senderos, espejos de agua y una enorme cantidad de árboles. Robles siempre verdes, robles comunes, arces azucareros y arces plateados se plantaron entre treinta especies de otras plantas incluyendo glicinas, vides en flor, vides gigantes de China, hierba silvestre, corteza cobriza de ciruelo y magnolias.

El sector norte del jardín, hacia el muelle Branly, presenta árboles altos mientras que el borde sur a lo largo de la Rue de l'Université ha sido plantado con hierba que crece naturalmente en bosques y zonas forestales junto con árboles florecidos como magnolias y ciruelos.

La apariencia visual asombrosa de los jardines está pensada para dar al visitante sorpresa y la inesperada experiencia de salida del entorno urbano de los

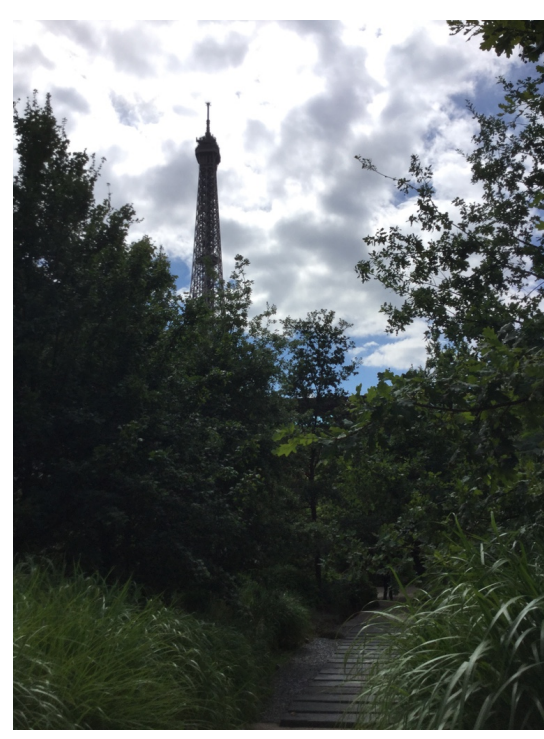

(Fig.9) Vista de la tupida vegetación. 
alrededores. Como una extensión del Campo de Marte, estos jardines fueron concebidos como lugares de placer visual totalmente abiertos, el sitio perfecto para un paseo, un lugar alegre en su más estricto sentido, con espacio para gran cantidad de personas en su café y donde los visitantes del museo,

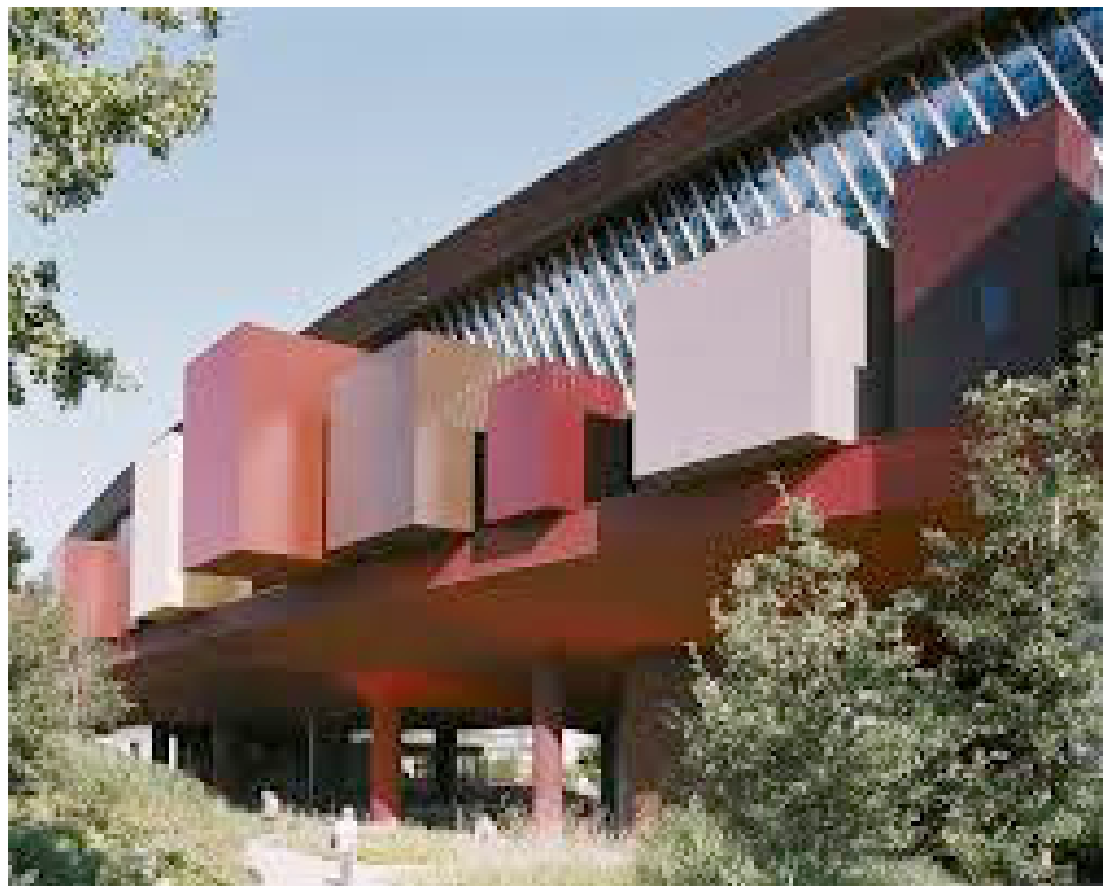

(Fig.10)

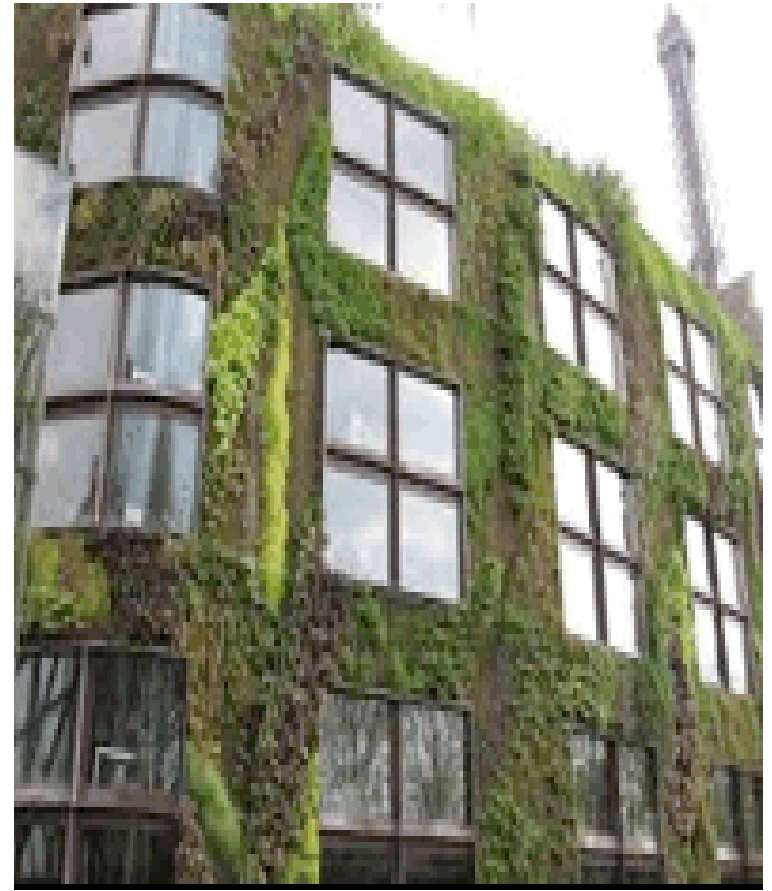

(Fig.11) Vista de la pared vegetal.

investigadores, estudiantes y turistas asisten a eventos culturales dentro del complejo donde pueden encontrarse.

El exterior de la fachada norte presenta veintinueve llamativas "cajas de colores" de diferentes tamaños que parecen suspendidas de la galería principal a diez metros sobre el nivel del suelo. Desde dentro del museo, estas cajas 
aparecen como una sucesión de compartimientos atravesados por un gran ventanal cruzado por soportes de madera. Cada "caja" aloja una selección de obras con un origen específico (africano o asiático) estimulando a los visitantes a descubrir la identidad de una gente particular o de una cultura específica. (Fig.10)

Las fachadas del museo fueron realizadas en el año 2004 cubriendo la totalidad de los muros exteriores del museo. Durante el verano, la fachada que mira hacia el muelle Branly se convierte en un destello de color: alhelíes, helechos, iris, heucheras, fuchsias y sauces fueron plantados en gran número formando un verdadero jardín colgante. (Fig.11)

Un total de 15.000 plantas de ciento cincuenta especies cubren una superficie de 800 metros cuadrados. Estas plantas representan la flora de diferentes regiones del mundo evidenciando la diversidad cultural del museo mismo.

La creación del "muro verde" del Museo del Muelle Branly involucró la experiencia artística de la arquitectura y de la botánica. Aquí también asocio sensaciones percibidas ya no solo por la vista sino por otras vías como el olfato y el oído. Impactan los perfumes y los sonidos, generados por la vegetación contra el viento y la presencia de pájaros e insectos.

Hay colores que invaden el espacio tales como el verde. De este color se podría decir que es un color maleable por su condición de intermediario entre el amarillo y el azul. Al equiparar la condición de ambos colores, se obtiene el carácter propio del verde. Este color manifiesta reposo y estabilidad cuando está en su punto justo de equilibrio, pero 
también, tiene la capacidad de movilizarnos cuando se siente atraído por sus extremos amarillo o azul. Es la expresión misma de la naturaleza. Es la calma, el reposo y la frescura en medio de la gran ciudad.

Interiormente, las paredes y especialmente los pilares, están revestidos con un revoque rugoso color ocre. El equipamiento presenta un color tabaco con una pátina de cuero, mientras que el piso tiene una terminación plástica que recuerda a la arena.

Está presente el naranja y sus matices. Este color es directo en su mensaje, aunque de menor intensidad comparado con el rojo. Este es por excelencia la fuerza cromática, es dinámico y enérgico. La correspondencia entre el rojo y el cuadrado, que simboliza la materia en reposo, expresa con claridad la firmeza de su carácter, pero al mismo tiempo, expresa tensión, actividad, vibración, características opuestas que confirma Kandinsky.

El amarillo, el ocre, particularizados por ser colores más luminosos, radiantes y activos, se presentan con un efecto de expansión que invade. Son los colores de la tierra que remiten a aquellos lugares lejanos.

Desde el tratamiento y el tránsito de la luz en la materia se presentan transparencias, translucencias, matices, reflejos y opacidades que ponen en juego la capacidad de aparición y evanescencia de los objetos.

El color es usado aquí con un carácter evidentemente escenográfico. El color y la iluminación son usados para evocar los ámbitos a donde pertenecen los objetos allí expuestos.

Es el uso del color que mediatiza la comunicación, hace que los objetos se presenten sugerentes con la intención de sumergirme en ambientes ajenos a su hábitat natural. 
Estos espacios creados desde la materia, colores, texturas, luces y sombras, expresan las ideas del diseñador respecto de tantas culturas olvidadas y menospreciadas. El color aquí, es protagonista del espacio y no una capa superficial en cuanto a los criterios de color referidos a la idea primigenia del pensamiento proyectual. (Fig.12)

El color y quizá también las texturas, poseen aquí una capacidad de unificación que no poseen otros elementos del diseño. Los contrastes que existen entre las diferentes formas del museo están expresamente atenuados al unificarse texturas y colores. De esta manera, éstas consiguen comunicarse naturalmente gracias al color.

Los materiales que conforman el espacio del museo, sean éstos porosos, no reflectantes y de bajo valor cromático, disminuyen

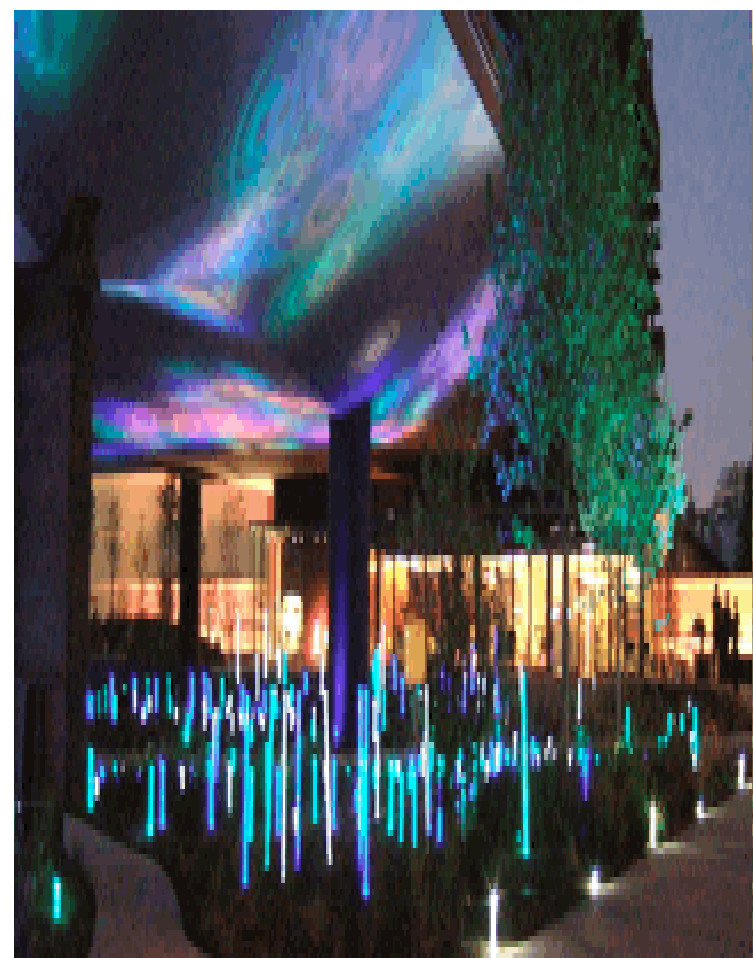

(Fig.12) Vista nocturna de los jardines.

los contrastes existentes entre volúmenes. Las formas dinámicas, como el envase mismo del museo, pierden movilidad al utilizarse texturas de grano fino y principalmente colores terciarios con valores bajos.

Desde un punto de vista semiótico, podría afirmar que los objetos son portadores de significación (valor de cambio/signo, según Baudrillard) que les permite ser denotadores o connotadores de distintos temas. 
El camino que se inicia en el emisor, el arquitecto proyectista, y que se concreta en formas y colores, continúa en el observador/protagonista que decodificará la imagen a partir de ciertos elementos objetivos y subjetivos,

recodificándola y generando un circuito que permite una significación permanente.

Si el color va por una vía separada o simétrica a la de la forma o como diría Breyer "el color no va pegado a la figura", que sucedería entonces con la forma despojada del color? Cómo sería la percepción de la forma sin color?

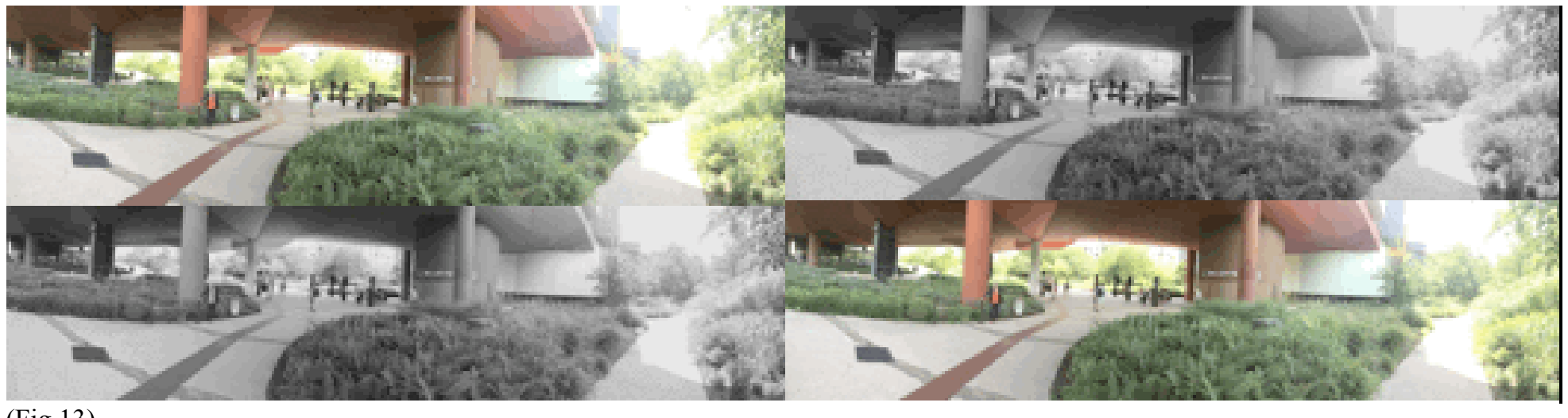

(Fig.13)

Si tengo registro de la obra en toda su policromía no sería tan extraña la sensación de falta total de color (acromía). Pero, notemos que experimentando la situación inversa, el efecto me dejaría absolutamente perplejo. 
Ciertamente el color y la forma son entidades separadas, dueñas de su propia existencia, por eso la palabra no puede definirlas y deja así al color su propia expresión, es fenómeno puro, aparición, que le da sentido a la forma. Es el fenómeno del color como color luz. (Fig.13) 


\title{
III. TRANSPARENCIA Y REFLEXIÓN
}

¿Cómo opera la luz como experiencia estética?

¿qué sensaciones provoca en el espectador cuando impacta sobre el material?

¿qué fenómenos surgen en su dispersión?

\begin{abstract}
El mundo sensible es "más viejo" que el universo de los pensamientos según la estructura y el sentido intrínsecos, porque el primero es visible y relativamente continuo, y el segundo, invisible y lleno de lagunas, no constituye a primera vista un todo y no tiene su verdad sino a condición de apoyarse en las estructuras canónicas del otro.
\end{abstract}

Merleau-Ponty, Maurice. Lo visible y lo invisible.

Editorial Nueva Visión. 1959. Pg.24.

Al hablar de transparencia y reflexión me refiero aquí, principalmente al material, esa pureza absoluta que Walter Benjamin asignó al vidrio (Walter Benjamin, Libro de los Pasajes, 1927-1940), y a cómo éste se encuentra iluminado o mejor dicho cómo está distribuida la luz sobre el objeto, lo que llamamos cesía. El vidrio puede ser claro u oscuro; transparente o reflectante, o sea que deje ver a través o que nos devuelva la imagen detrás nuestro. 
Estos son variados niveles de visibilidad; es el vidrio que ofrece variadas formas de comportarse frente a la incidencia de la luz.

Nuestra percepción de los hechos físicos se produce decodificándolos e interpretándolos como signos visuales. Es así que percibimos cualidades de los objetos que se encuentran en nuestro campo visual, estas son: nivel de claridad u oscuridad, opacidad, brillo, transparencia, traslucencia, reflexión, etc. Son estas cualidades a las que se ha dado en llamar cesía. Las cesías son, entonces, signos visuales. Percibimos determinadas cesías sin excluir, obviamente, las características de color, forma y textura que identifican a los objetos.

Aquí cabe la clasificación que Caivano propone al respecto: (Ilusiones y efectos visuales que involucran distribución espacial de la luz. Actas del Cuarto Congreso Argentino del Color.1998)

- Transmisión regular (transparencia). Una superficie transparente se comporta como un filtro restando radiación del fondo, de tal manera que lo vemos más oscuro.

- Transmisión difusa (traslucencia). Una superficie traslúcida transmite algo de radiación y refleja otro tanto en forma difusa.

- Reflexión difusa (apariencia mate)

La luz no puede iluminar un espacio sin que exista un material que la refleje. Es, entonces, el material el que hace posible el efecto lumínico y de él depende el efecto espacial que la luz produce. 
Con referencia al caso que me ocupa, Ignasi De Solá-Morales (2002), afirma que "la innovación que pretenden aportar estas arquitecturas no es sólo constructiva, es decir de aplicación de nuevas posibilidades mecánicas, sino sobre todo de comunicación y de gestión. En todos los arquitectos, esta tendencia, el énfasis más destacado, se pone por una parte en la eficacia con la que nuevos artefactos explican sus funciones, exhiben sus objetivos, muestran su lógica técnica. Es el triunfo de la comunicación a través de las imágenes de una arquitectura de la transparencia y de la inmaterialidad creciente".

El color, la textura, el brillo, la reflexión y la transparencia, se manifiestan en toda su intensidad gracias a la luz que los hace posible. El brillo es una característica superficial de la forma que tiene relación con la textura del material. Con relación al vidrio, la incidencia de la luz determina que éste absorba o refleje los rayos haciendo del material un elemento multifuncional o "mágico" si observamos su comportamiento sensible.

En los paneles vidriados del frente del museo del Muelle Branly sobre el río Sena, al igual que en el edificio de la Fundación Cartier (Fig.14), (dos obras del arquitecto Jean Nouvel en París), se mezcla la imagen virtual y la imagen real. No se sabe si se ve el cielo reflejado o el cielo en transparencia. No se sabe si los árboles están adelante o atrás de la fachada vidriada o si es un reflejo. Son juegos. Son los trazados de los planos que desorientan. Son trucos, artimañas, son imágenes que aparecen y desaparecen. Son efectos de apariencia, de desmaterialización, de creación de una atmósfera misteriosa y singular. Es la magia y la ilusión. 

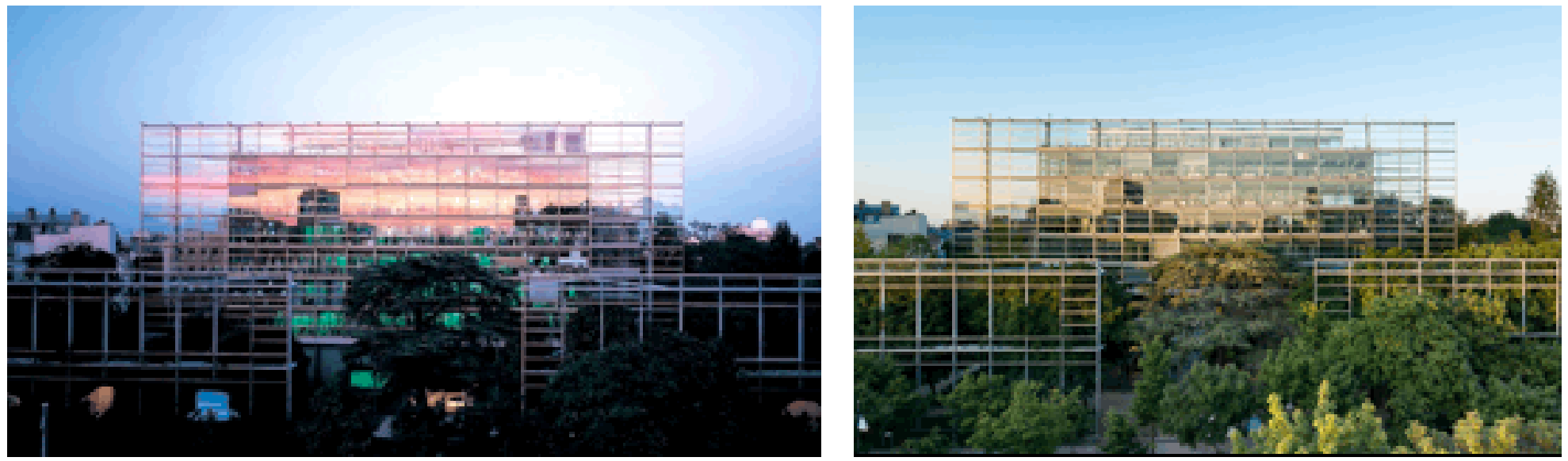

(Fig.14) Fundación Cartier. París, 1994.

Es la aparición de una imagen que surge sin explicación aparente. Las apariciones se sirven, en el diseño de Nouvel, de un truco previo, estableciendo las diferencias entre enmascaramiento, simulación, disimulo y ardid. La aparición de las imágenes acontecen y son reales ante mis ojos o desaparecen y son invisibles. Esta desaparición se da mientras que mi recorrido por el espacio produce el acontecimiento o cuando la luz incide de una determinada manera sobre la superficie de los planos vidriados. Estos efectos de aparición-desaparición pueden ser congruentes con el lugar al que pertenecen devolviendo la imagen real u otra ilusoria. Aclaremos que según Pierce, la realidad es lo que la comunidad acuerda en considerar como tal.

En el Museo del Muelle Branly (París, 2006), Jean Nouvel utiliza una configuración de diferentes pantallas de vidrio a través de las cuales se entrevé su estructura, el espacio selvático interior, la volumetría del museo mismo, jugando con la reflexión y la transparencia para confrontar el edificio con su entorno inmediato. 
Mientras que el emplazamiento y la escala de las pantallas frontales de vidrio son los objetos principales a través del cual el edificio refleja el espacio urbano, es la idea de su diseño y sus detalles lo que hace su efecto categórico. Por ejemplo, la estructura de las pantallas es visible desde detrás de todas las superficies de vidrio, lo que promueve la ilusión de crear un reflejo a través de la generación visual de una superposición de diferentes líneas geométricas. La estructura es reducida a una retícula abstracta, y esa retícula es constantemente contrastada contra las superficies reflectantes de los demás paneles. El arquitecto eligió aquí exponer la estructura de acero a lo largo de todo el frente, poniéndola al servicio de los deseados efectos ilusionistas.

En este proyecto, los espacios detrás de los planos de vidrio son así percibidos como un cambio de reflexión y densidad de la luz detrás del cristal.

La intención de Nouvel de proyectar la ambigüedad, la dualidad, lo incompleto o lo sugestivo, manifiesta el deseo de transmitir que lo más importante son los efectos producidos por los materiales y su disposición dentro de la obra frente al espacio urbano circundante. Es un lenguaje que pretende que el observador sea más emocional que analítico. Pallasmaa se refiere a esta polémica sobre la verdad tectónica de un material en relación con su capacidad fenomenológica. En él se denuncia el énfasis excesivo sobre las dimensiones intelectuales y conceptuales de la arquitectura que apuesta por los materiales tecnificados, contribuyendo a la desaparición de su esencia física, sensual y corpórea. Para él los materiales sintéticos no disfrutan de una valoración positiva porque no poseen la capacidad de los materiales naturales para mostrar su esencia, es decir, carecen de autoridad de presencia. 
Los productos de la tecnología instrumentalizada ocultan sus procesos de construcción, mostrándose como apariciones fantasmagóricas donde el uso de los materiales reflectantes refuerza la sensación de ensueño, de irrealidad, de alienación.

Pallasmaa, Juhani. Los ojos de la piel: la arquitectura y los sentidos. Editorial Gustavo Gili. 1978.

Y esto es lo que justamente Nouvel pretende para su obra, provocar en el observador estas distorsiones perceptuales que es la esencia de la idea con la que elabora toda su arquitectura.

A través del reflejo, Nouvel logra incorporar a la ciudad dentro de la composición, creando una morfología que incorpora materiales esencialmente dinámicos. De esta manera, y a través del diseño, contrapone la concepción dinámica de su obra con la imagen estática de la arquitectura convencional ayudado por una tecnología en constante avance que facilita la puesta en escena de esta nueva arquitectura.

Tradicionalmente la estabilidad de los materiales era deseable: la obra valía por la estabilidad de la estructura del edificio. Actualmente la innovación se considera que ha contribuido a superar los cánones tradicionales, y la utilización de los materiales versátiles, como el vidrio, pueden contribuir a una nueva percepción del espacio arquitectónico.

Con la superficie de las pantallas vidriadas se obtiene un plano monolítico en toda su extensión que definen los espacios interiores y exteriores del conjunto edilicio. (Fig.15). Ofreciendo poco margen para cualquier distinción en la articulación de la fachada, estos muros exteriores no registran ni representan el orden interno del conjunto: 
estas pantallas disfrutan de esta habilidad particular para permanecer fuera del edificio del museo sin manifestar una pérdida en su integridad espacial.

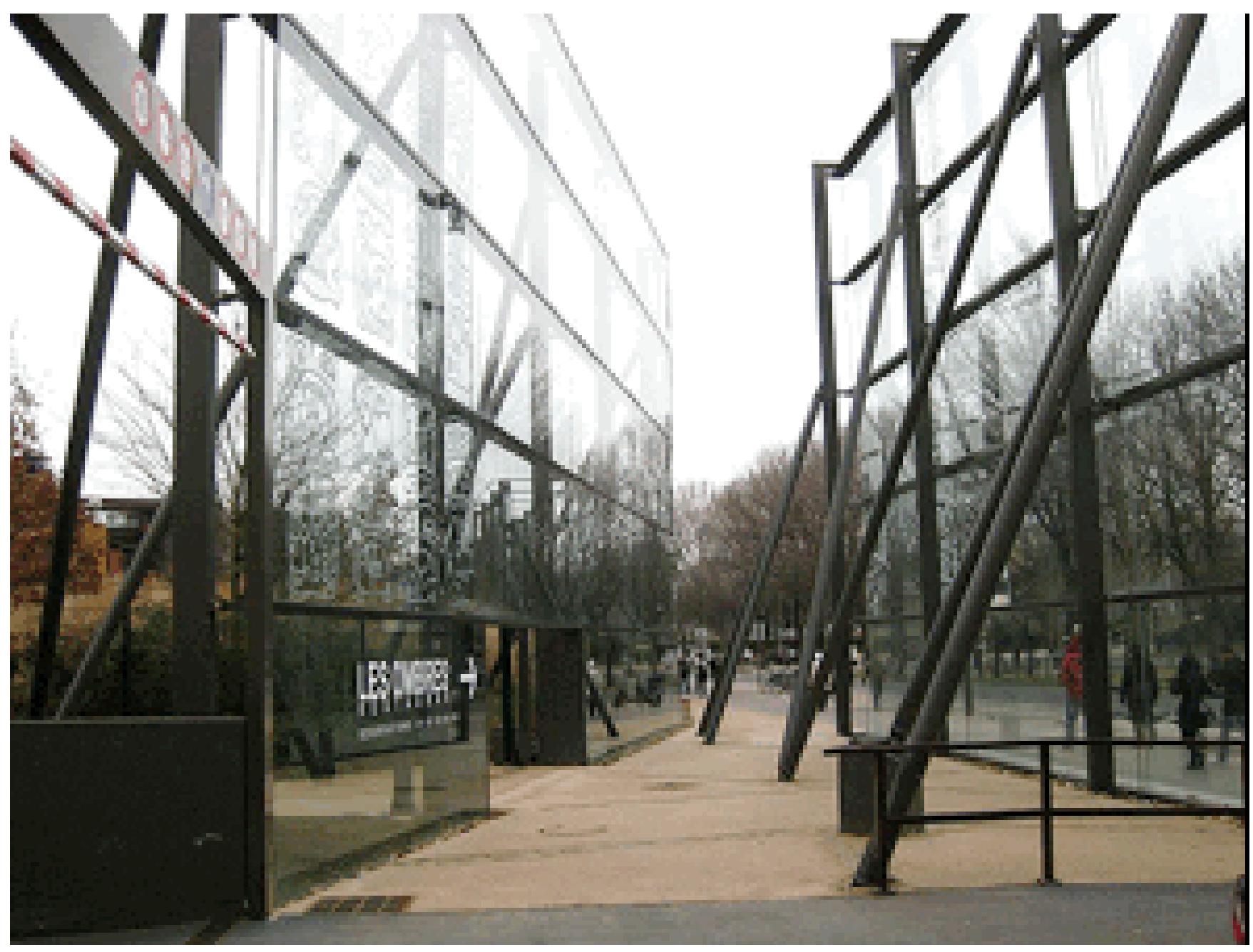

(Fig.15) Vista de los planos vidriados de la fachada norte. 
La unión del peatón en el ambiente urbano del museo, presagia una suerte de prestidigitación. Jean Nouvel crea un ambiente de desestabilización, de irresolución, vértigo y simulación.

Se pierde el sentido del plano y aparece la transparencia como modo de actuar en la arquitectura. Aparece la sorpresa como mecanismo entre arquitectura e ilusión. "Simular es fingir lo que no se tiene" (J.Baudrillard. 1978).

Jean Nouvel elimina de la obra cualquier objeto que no debería estar ahí, solo coloca allí lo imprescindible para crear los necesarios efectos ilusorios.

El vidrio aquí es transparente o espejado? Es las dos cosas, incluso teniendo grados intermedios de semi-espejado lo cual depende del grado de iluminación interior y exterior del edificio y del ángulo desde donde observamos el plano vidriado.

De hecho, la primera intención detrás de esta serie de planos de vidrio es la generación de un conjunto de planos reflectantes y transparentes manipulando la imaginería del espacio urbano en el que se insertan, logrando de esta manera que los planos vidriados del edificio se incorporen a la imagen de la ciudad. Vistos a través de los planos vidriados y reflejados contra éste, se logra la reflexión de la actividad febril de la ciudad.

Aquí, la ilusión construye un signo hacia algo distinto, es una arquitectura del otro lado del plano virtual. Es el límite, es la frontera donde todo ocurre, lo real y lo irreal, lo visible y lo invisible. Es nuevamente la noción de L. Carroll y los estoicos. El borde donde todo ocurre. 
En la novela de ciencia ficción de Robert Heinlein "La desagradable profesión de Jonathan Hoag” (1942) el autor nos cuenta la situación de los protagonistas en el interior de un automóvil mientras que una niebla gris invade el exterior: “...Lo esencial es el lugar desde el cual lo irreal irrumpe: la frontera que separa lo interior de lo exterior, materializada en este caso por el vidrio de la ventanilla. Es la experiencia fenomenológica de la barrera que separa lo interior de lo exterior, esta sensación de que lo exterior es en última instancia ficticio...invisible, no verdadero".

La pantalla, la fachada del edificio, se convierte en el lugar donde no tiene lugar nada, salvo el lugar mismo. Nouvel traslada a la superficie todo el potencial de su arquitectura siendo consciente de los efectos buscados.

Este plano de proyección, modulado a partir de algún sistema de relación de proporciones numéricas podría ser considerado como un espacio donde la ciencia y la ilusión configuran un nuevo mundo.

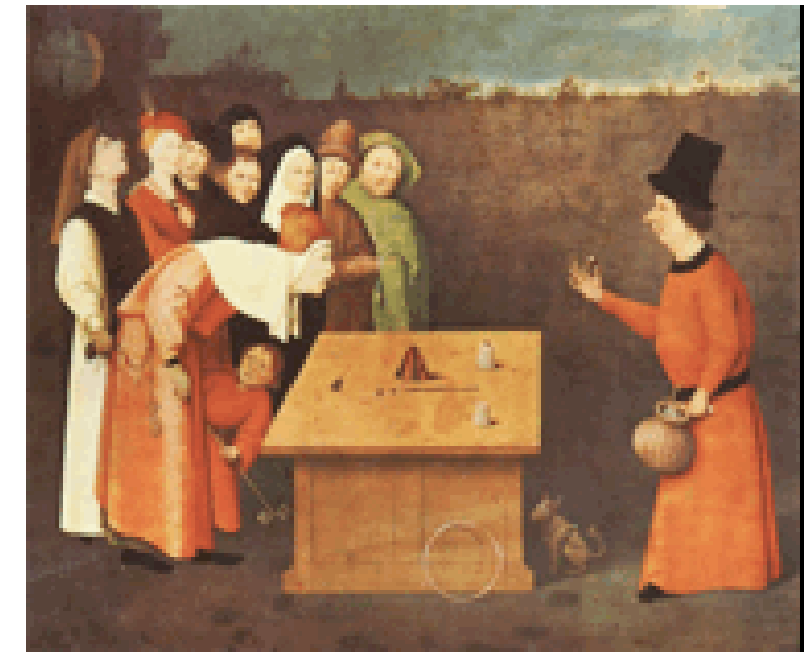

En el truco visual no se trata nunca de confundirse con lo real, sino de producir un simulacro, con plena conciencia del juego y del artificio.

Jean Baudrillard. Cultura y simulacro. Pg.17. Editorial Kairos.

Barcelona. 1978. 
El Prestidigitador (Fig.16), de Hyeronimus Bosch (1475-1505), se constituye en la primera representación donde la habilidad para la captación de la atención es empleada con la finalidad de engañar y aunque Nouvel no se considera un prestidigitador, él construye espacios de seducción, espacios virtuales de ilusión concebidos a partir de estrategias de distracción. Son espacios donde no se sabe donde está el límite. Es la desmaterialización del espacio, la percepción de lo sensible, donde la intención no es la materia sino lo inmaterial, es otra cosa diferente a lo obvio del material aunque él es el vehículo que hace posible la magia. Es lo que Graziella Trovato llama "transparencia erótica" que no es más que el juego entre lo que se cree ver y lo que se está viendo (el velo y el des-velo) que nos sumerge en una inquietante incertidumbre.

La percepción, es entonces la conexión entre arquitectura e ilusionismo. La transparencia aquí está lograda con el juego de la luz, lo que aparece y desaparece. El tiempo y la luz están presentes para posibilitar los efectos efímeros de una arquitectura de la transparencia y la reflexión.

Son efectos de virtualidad, de apariencia. Es el efecto de la transparencia lo que nos sugiere la noción de evaporación y es así que cuando un objeto se "evapora" ante nuestros ojos, se vuelve transparente, invisible, deja de ser verdadero.

Tanto en los planos vidriados superpuestos de la fachada hacia el río como en la disposición interior de los objetos exhibidos, Nouvel logra efectos de yuxtaposición que hacen a las superficies vibrar en un conjunto sorprendente. Es lo que observa Colin Rowe y que Solá-Morales ratifica en cuanto a que aquí estamos ante una 
evidente transparencia fenoménica y no así literal como pudiéramos observar en tantos otros ejemplos de la arquitectura moderna. Está claro que esta arquitectura muestra un fluir permanente de los materiales utilizados y el efecto de la luz que hace que los objetos se nos presenten casi como inmateriales. Por citar otro ejemplo, éste es el caso de la Farnsworth House donde Ludwig Mies Van Der Rohe exhibe la transparencia total de la obra.

Dice Jean Novel: "Transparencia es también trans-apariencia" y al hablar de transparencia y reflexión también estamos hablando de ilusión. Nuevamente, este concepto nos remite a algo irreal, aunque varias definiciones pueden contradecir esta idea. Podría decir entonces que:...

La ilusión es contradicción o conflicto que surge entre dos o más formas de conocimiento. Diferentes formas de conocimiento provienen de diferentes sistemas de mediación entre sujetos y objetos, entre cognición y realidad externa. Estos sistemas de mediación pueden ser distintos sistemas de signos de los cuales se derivan significados, distintos aparatos sensoriales con los cuales incorporamos nuestras experiencias perceptuales, distintos modelos mediante los cuales interpretamos los fenómenos.

\section{Caivano, José Luis. Actas del Cuarto Congreso Argentino del} Color. 1998. Pg.246.

Considerando el mundo exterior a cada uno de nosotros, lo que percibimos son signos que se podría decir que vienen con una interpretación previa concebida por nuestro propio sistema de valores o como expresa Merleau Ponty “Hay pues otro sujeto debajo mío para quien existe un mundo antes de que yo esté allí donde él señalaba mi 
lugar. Este pensamiento cautivo o natural es mi cuerpo”. (M. Merleau-Ponty. Fenomenología de la percepción, París, 1945).

Pero si me refiero a estructuras cognitivas incompletas, el acto de rellenar información según la experiencia personal y lógica se da cuando los datos de los que dispone el observador resultan insuficientes..."Un mundo percibido no se le aparecería a un hombre si esas condiciones no estuvieran dadas en su cuerpo" (M. Merleau-Ponty. Lo visible y lo invisible, 1959. Pg.32). Y noto que es ésta una idea concordante con la teoría inductiva aristotélica sobre la percepción, cuando éste afirma que no hay nada en el entendimiento que no haya estado antes en los sentidos.

¿Qué significa, entonces, esta suerte de predicción o adivinación? ¿Lo previamente asimilado nos alerta sobre los misterios del espacio observado?

La reversibilidad de lo visible en los planos vidriados que limitan el área del museo con la ciudad nos muestra dos realidades sobre la misma cara, o sea, no es necesario que el espectador se sitúe en ambos lados, basta con que permanezca allí observando sin ir más allá de este límite. Este es el quiasmo ${ }^{2}$ llevado al hecho material: la reversibilidad, el desdoblamiento, es un acto de dos caras que plantea esta ilusión.

Al hablar de ilusiones visuales estaríamos representando un mundo de ambigüedades donde se darían múltiples interpretaciones. Es este mundo de incertidumbre, de indecisión, de contradicciones y diría de "incompletud" porque eso que observamos no termina de ser. Entonces, más correcto sería referirnos a una realidad semiótica que

${ }^{2}$ Quiasmo: El quiasmo es una figura retórica basada en la repetición. Se trata de un paralelismo cruzado, es decir, de la repetición de una estructura sintáctica; con la particularidad de que en el caso del quiasmo los elementos que se repiten aparecen primero en un orden (por ejemplo, $\mathrm{AB}$ ) y luego en el orden contrario (por ejemplo, BA). 
a una realidad física que es la que somos capaces de conocer. Son las ilusiones, invisibilidades que están allí sin ser

objeto material y tangible, es la "trascendencia pura, sin máscara óntica" como expresa Merleau-Ponty.

¿Qué es lo que está en juego en el vidrio? La transparencia y la luminosidad pero también la posibilidad de capturar la luz, de hacerla jugar. Y al hacer jugar la luz sobre el vidrio, a través del vidrio, se está justamente en el proceso de darle forma al mundo, al mundo material, al mundo de la luz, del sol, de las velas y de todas las demás luces. Se está en el proceso de dar una forma, lo que no es otra cosa que un nuevo juego de la luz, no es otra cosa que hacer brillar la luz. Y "hacer brillar la luz" significa en latín pasar de lumen, la luz que se fija sobre las cosas, a lux, la luz original, la luz que ilumina, la luz de fiat lux, la luz que se remonta a la creación del mundo. No estoy diciendo que Parmiggiani (fig.17) nos ponga en contacto directo con la creación del mundo, simplemente quiero sugerir que en todo gesto artístico se propone algo de ese orden.

Nancy, Jean-Luc. Conferencia en la Academia de Brera. Milán, 2006

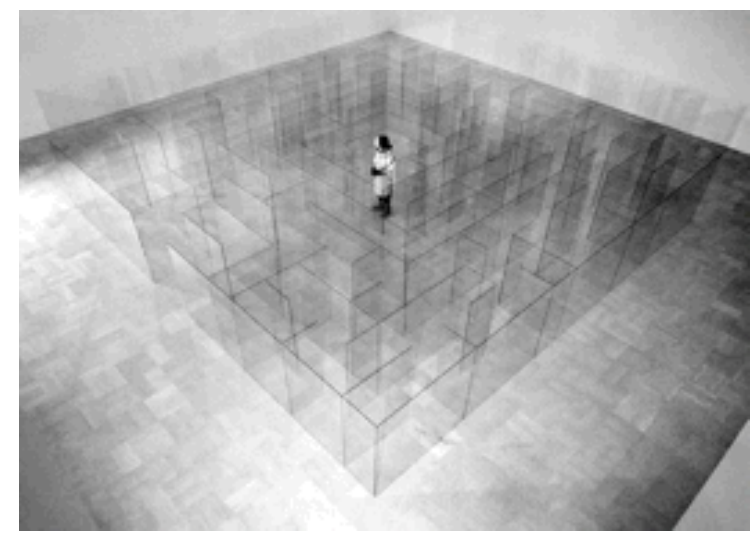


Todo esto no queda lejos de lo que Lévi-Strauss denominaba, en términos lingüísticos, el exceso de significante: la idea de que el significante está ahí de entrada, esparcido por todas partes, en una profusión que no agota jamás, afortunadamente, el significado. Este orden superabundante de significante es el de la magia (y de la poesía), no es un orden del azar ni de lo indeterminado, nada de eso, es, por el contrario, un orden regulado, de una necesidad muy superior a la que regula el acoplamiento del significante y del significado...

Jean Baudrillard. Las estrategias fatales. Pg.154. Editorial Anagrama.

Barcelona. 1984 


\section{ッ. TIEMPO, EMOCIÓN Y RECUERDO}

¿Luz y tiempo: cómo condicionan la conciencia del observador?

¿Qué rastros dejan en nuestra memoria?

La conciencia es el tiempo de la duración.

El sujeto vive el presente con el recuerdo del pasado y la anticipación del futuro.

Éstos solo existen en la conciencia que los contiene.

Bergson, Henri. Ensayo sobre los datos inmediatos de la conciencia. Ediciones Sígueme. 1999.

Con respecto la Teoría de la Relatividad y la relación que tiene con el arte y la arquitectura, se hizo evidente una concepción de espacio-tiempo que contemplara las cuatro dimensiones. Junto a esto, la indeterminación de las medidas de espacio y de tiempo, significaron la importancia de entender la materia como energía. En Bergson, esta concepción es superada a favor de un nuevo concepto: la plasticidad. Es que Bergson va más allá de la idea mecánica de la relación espacio-tiempo, considerando que en este par existe una cuestión de duración, de dilatación temporal que considera a la experiencia intuitiva como conformadora de la modificación y ampliación de los acontecimientos. 
Bergson diferencia la experiencia de los sucesos exteriores de la experiencia interior de nuestra conciencia. La ciencia considera a la experiencia exterior como una sucesión de acontecimientos factibles de ser medidos y cronometrados, cuestión que hace de los hechos, acontecimientos fijos capaces de ser entendidos en términos de lo cuantificable. Así, Bergson llama a esta realidad exterior como hechos que manifiestan "simultaneidad", son datos que se suceden unos a otros donde uno desaparece cuando otro suceso se impone en el devenir de los acontecimientos.

La experiencia del devenir en la realidad de los procesos de nuestra conciencia es entendido por Bergson no ya como una simultaneidad de acontecimientos cuantificables sino como experiencia múltiple desarrollada en el tiempo que constituye la “duración”, donde los términos dilatación y ampliación son parte del mismo fenómeno. Son datos de nuestra experiencia de lo múltiple. Es lo múltiple lo que confiere una continuidad a nuestra experiencia de la duración. Existe también, una dilatación que no viene dada por los datos de la experiencia externa sino que solo se produce en nuestra percepción consciente de aquella realidad que solo es aprehensible en la discontinuidad numérica de los hechos exteriores. Es ésta una experiencia de lo "cuantificable" contra la experiencia de lo "cualificable". Ciertamente, no podríamos definir a la experiencia interna de nuestra conciencia como dato susceptible de abarcarlo numéricamente, solo es pasible de ser entendido en términos de calidad perceptual.

En el museo Branly es el accionar intuitivo de nuestra experiencia sensorial que nos sitúa en un ejercicio de lo múltiple. Lo múltiple en la experiencia exterior pertenece a un medio homogéneo que es el espacio donde las 
cosas se suman. Es el espacio cuantificable que a su vez las hace permanecer distintas. Por otro lado, debemos considerar que la sensación, en nuestro caso la experiencia estética, es intensidad, es la fuerza de la conciencia, nunca es magnitud. Así, esta práctica nos permite ser parte de una arquitectura de categorías cambiantes, fluidas, y casi “mágicas" reunidas en una misma obra.

¿Cómo medir, entonces, la experiencia estética de la obra? En el devenir de la experiencia intuitiva, nada es medible, o acaso ¿podemos medir nuestros pensamientos y nuestras emociones? Ya lo dicho por Bergson cuando anuncia lo cualificable de nuestras intuiciones. Y he aquí lo que Solá-Morales llama a esta arquitectura un sistema de acontecimientos donde espacio y tiempo son categorías abiertas que conviven en nuestra experiencia intuitiva sin que esto signifique un sistema cerrado sino que por el contrario expresan sistemas capaces de incorporar nuevos modos de experimentar lo que nuestros sentidos son capaces de captar. Si solo tuviéramos la capacidad de captar lo que sucede en un solo instante, ahora mismo, no podríamos percibir la experiencia de la duración, de la extensión en el tiempo, es crucial, entonces, tener en cuenta la conciencia del tiempo para comprender la relación entre percepción y recuerdo.

No hablo aquí de aspectos técnicos o científicos sino como ejemplo de la expresión artística y de la capacidad creativa que tiene nuestra conciencia que hace de este campo intuitivo algo inaccesible a la ciencia.

La experimentación de los aspectos cinestésicos está presente desde el acceso al predio del museo. Me refiero a la experiencia del tiempo planteada desde las áreas exteriores hasta el espacio interior donde están alojadas las obras. El tiempo como flujo de nuestro transitar se hace evidente al atravesar el bosque que rodea al edificio. 
Posteriormente, el "río" o sea, la rampa que nos deposita en la gran nave longitudinal por la que podemos deambular sin detenernos (Boris Groys, 2014) nos deja librados a la experiencia del fluir de los acontecimientos, a la experiencia intuitiva de la duración que nos aleja de las visiones simultáneas, estáticas y fijas de una cultura que ya no pertenece a la experimentación contemporánea de los acontecimientos como ejercicios de una cultura que va más allá de lo visual para sumergirse en la experiencia de lo múltiple y de lo dinámico.

Aún, para Gilles Deleuze, las dos realidades, la de los acontecimientos exteriores tanto como la de nuestro mundo interior constituyen una única realidad conformada por los distintos pliegues de un continuo. Esta explicación de los acontecimientos del mundo, se ve reflejada en los intentos de toda arquitectura contemporánea que trate de mostrarnos la diversidad de la experiencia del tiempo, donde en realidad no hay tiempo sino tiempos que explican el transcurrir de los acontecimientos como es el ejemplo del Museo del Muelle Branly.

Esta multiplicidad de la experiencia espacio-temporal es la buscada en la arquitectura contemporánea. Esta responde a condiciones socio-económicas y culturales actuales de concebir sus obras.

Queda así superado el concepto estático vitruviano de la duración entendida desde sus materiales y conceptos estéticos. El muro sólido ha sido reemplazado aquí por nuevas tecnologías que han hecho posible la desmaterialización de los límites del espacio, permitiendo que la experiencia de los sucesos espaciales y de la duración temporal, se produzca a través de lo que Ignasi de Solá-Morales llama la "arquitectura líquida", o sea una arquitectura del flujo, de lo múltiple y abierto. En Vitruvio y toda la arquitectura clásica, el sentido de estabilidad, permanencia y solidez era fundamental dadas las condiciones de la cultura a lo largo de los siglos. Este paradigma ha 
sido derrotado por la modernidad que evolucionó hacia una forma abierta y "plástica" de experimentar la noción temporal del espacio.

Cuando la luz es un elemento que contribuye a la experiencia intuitiva de vivir los espacios contemporáneos, estamos en presencia de estas nuevas categorías de la arquitectura que hace posible una nueva visión del mundo actual. Es la experiencia vivida y sentida en el ejemplo que me ocupa: el Museo del Muelle Branly.

La prioridad del evento, del acontecimiento, supone un desplazamiento fundamental desde la preocupación por la permanencia y la durabilidad hacia lo instantáneo, ocasional, imprevisible y fugaz.

¿Es posible pensar una arquitectura del tiempo más que del espacio? ¿Una arquitectura cuyo objetivo sea no el de ordenar la dimensión extensa sino el movimiento y la duración? Hoy, más que nunca, nos interesan unas arquitecturas que están a medio camino entre el espacio y el tiempo, viviendo en la tensión de las prioridades opuestas.

De Solá-Morales, Ignasi. Territorios. Editorial Gustavo Gili. 2002. Pgs. 26 y 27.

Abandonar abruptamente la ciudad, con sus sonidos, formas y colores particulares, al interior que ocupa el museo es cruzar "al otro lado del espejo". Se puede recorrer y observar una selva tupida, llena de especies vegetales de distinto porte, árboles, arbustos y helechos que pueblan el espacio. Camino guiado por los senderos que corren entre las columnas que semejan árboles. Son ellas las que sostienen un enorme volumen suspendido a diez metros 
de altura. Es el cuerpo mismo del museo. Al dirigir la mirada a mi alrededor la selva está presente en todas las direcciones; se escucha el sonido de los pájaros pasar y el de la brisa que sopla entre la vegetación.

En este deambular, se puede sentir la emoción por lo que pareciera va a suceder en la próxima curva del camino. La luz va marcando el tiempo y modelando los lugares al atravesarlos. Las sombras son dramáticamente atravesadas por la potente luz del mediodía que viene de lo alto.

Según Paul Valéry: Que un edificio sea inmóvil es la excepción, nuestro placer deriva de movernos a su alrededor como para hacer que el edificio se mueva a su vez, mientras disfrutamos de todas esas combinaciones de sus partes. A medida que van variando, las columnas giran, las profundidades retroceden y las galerías se deslizan, miles de visiones se escapan.

Holl, Steven. El método de Leonardo citado en "El Croquis" 78, 93, 108. Editorial El Croquis. 2003. Pg.80.

Durante el recorrido, aparece el recuerdo de aquellos lugares lejanos, ajenos a lo cotidiano, esos territorios ocupados por culturas olvidadas y que aquí son vueltos a la vida por efecto de la arquitectura. Efectivamente, la idea del proyectista es transportar al visitante en el tiempo y hacia otro lugar y, ¿qué lo hace posible? Sin duda, la luz que permite a cada objeto hacerse presente y, el recorrido, la secuencia, el desplazamiento que se llama tiempo. El espacio es percibido entonces, por mi cuerpo moviéndose a través de él, es el tiempo convertido en espacio. 
"Para llegar a la idea de exterioridad, hace falta el movimiento, la actividad motriz" (Gilbert Simondon "Curso sobre la percepción" (1964-1965. Pg.75) sobre Destutt de Tracy en "Mémoire de 1'institut". 1798).

Podría afirmar entonces, que la percepción de un objeto no termina simplemente en las tres dimensiones del espacio, deberíamos experimentarlo desde innumerables posiciones. Aunque no son solo estas alternativas, hay que considerar el desplazamiento alrededor de éste lo que hace posible el par indisoluble: el espacio-tiempo.

Los espacios interiores y exteriores del museo se organizan en torno a la luz y al tiempo. Las aberturas en la piel del edificio han sido diseñadas de acuerdo con el movimiento del sol a través de la sección del edificio. El volumen interior atrapa determinados momentos de luz según la orientación de los frentes.

La luz se atenúa y aparece el río. Una rampa serpenteante corre "río arriba" hacia la cueva interior. (Fig.5) La escasa iluminación contrasta con la luminosidad de las palabras que corren por el piso, ondulantes, como un río en movimiento. Palabras que evocan lugares, cualidades que remiten a situaciones propias de aquellos lugares misteriosos y lejanos. La Luz y su movimiento es lo que hace que cobren vida esos espacios.

Y en la Arquitectura, ese movimiento de la luz es real. Y si se consigue el diálogo entre el espacio, la luz que lo recorre y el hombre que lo habita, allí aparece la Arquitectura. Algo muy fácil y muy difícil a la vez.

Campo Baeza, Alberto. El blanco certero. Revista Baumeister. 1992. Pg.50. 
El río me deposita en la cueva interior, la luz es lo que uno pudiera imaginar de un lugar cerrado, interior, profundo. La cueva, donde se encuentran los objetos expuestos, es profunda, alta y de una notable longitud.

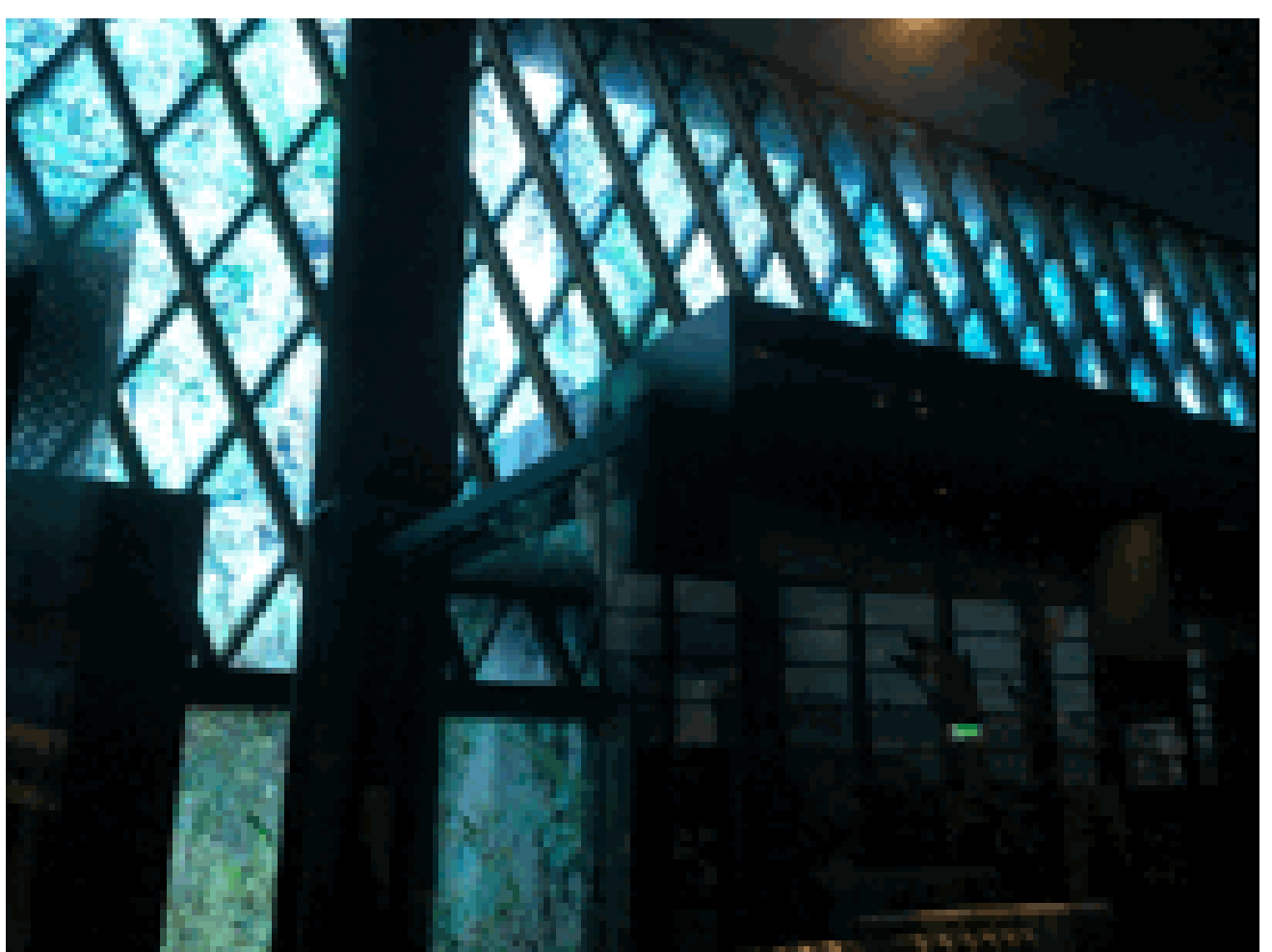

(Fig.18)
Los paramentos verticales que la encierran tamizan la luz, la controlan mediante lamas exteriores y los soportes cruzados de los ventanales de la fachada norte. (Fig. 18)

Ha transcurrido un tiempo prolongado desde el ingreso al museo. Ese tiempo va llenando de sensaciones a medida que uno transita estos espacios a la vez que va cargando de recuerdos que luego formarán parte de la memoria y que

se sumarán a un saber anterior. La arquitectura es expresión del tiempo, y el Museo del Muelle Branly se sitúa en él como lo hace respecto al lugar. La luz y la forma llevan dentro de si al tiempo y el tiempo es arquitectura. 
Dice Jean Nouvel:

Entre cine y arquitectura existe siempre una fuerte relación en mi obra. Tenemos las mismas pulsiones... Yo he aprendido mucho del lenguaje del cine. Sobre todo en el nivel de la relación de la consciencia cinematográfica y la relación tiempoimagen. En mi arquitectura hay mucho que debo al sentido del montaje del cine, al tiempo, el movimiento, el silencio, la sombra y la luz... tiene mucho que ver con la memoria". Y añadió: yo me planteo un edificio como si tuviera que atravesarlo paseando, hay veces que quiero sombra, o luz, o silencio...

www.levante-emv.com > Cultura. 2008.

Esta arquitectura es un decorado para crear una puesta en escena. La intención es que sea observada, y vivenciadas las situaciones que se suceden, es decir, está hecha para crear espectáculo como si de una película se tratara. Y observo aquí, ciertas similitudes en la concepción cinematográfica y en el planteo escenográfico con el film de Federico Fellini: "Il Casanova, film enteramente rodado en estudio que conserva el rigor histórico donde se desarrolla la vida del escritor Giacomo Casanova. A través de las imágenes, somos transportados a épocas lejanas, más precisamente al siglo XVIII en Europa, zona de influencia del libertino veneciano.

En esta película prevalecen definitivamente las escenas de una realidad ficticia y afectada. Casi nada en la película tiene su correlato con el ambiente natural tal cual lo conocemos, son lugares misteriosos, con un despliegue 
profuso de artificios escenográficos. Este ambiente de total efectismo está logrado enteramente en los estudio de Cinecittà.

La riqueza y el talento de Fellini, al igual que Nouvel, para lograr estos efectos ciertamente surrealistas, es por su efecto narrativo y por su habilidad para mostrar el par que conforman los aspectos fabulosos de aquellos ambientes lejanos con lo onírico y fantasmal. El film despliega un espectáculo visual sorprendente, con maravillosas y a veces "patéticas" escenografías, con deslumbrantes vestuarios e impresionantes maquillajes. Digo "patéticas" no como sinónimo de "desagradables” sino turbadoras y dramáticas como es el caso del mar de plástico, y digo inmensa artificialidad, océano de plástico. Fellini nos muestra esta intención desde el mismo comienzo, quedando claro que todo es artificial y "simulado".

En esta película transitamos por una sucesión de escenarios fantásticos y es a través de ellos que Casanova y nosotros mismos somos llevados por los caminos de un interminable sueño.

El lenguaje visual recargado que despliega Fellini está en los variados aspectos que va mostrando la película, el relato es extraño y se desenvuelve dentro de una atmósfera misteriosa de ilusión y fantasía. La realidad se ve opacada ante un mundo de quimera y alucinación y es justamente allí donde estamos en presencia de un ambiente visiblemente surrealista. Lo onírico y lo fantástico aparecen explícitamente en Il Casanova y esto nos demuestra la preocupación que tiene Fellini respecto del mundo de los sueños. Paralelamente, hay una conexión muy fuerte con el psicoanálisis, el mundo de lo desconocido y lo oculto. 
Quisiera resaltar aquí, el manejo expresivo y apasionado que hace tanto de los espacios exteriores como de los interiores, espectáculo casi virtual y mágico ciertamente, que lo conecta sin dudarlo con la imagen surrealista que domina su visión del mundo.

La mirada del surrealismo hacia todo lo vinculado a los sueños demuestra que éstos no funcionan como un evasión de la realidad, sino una postura revolucionaria frente a una sociedad demasiado estructurada en la que se propone la posibilidad de practicar algunas de las ideas de Freud con respecto a la asociación libre de aquellas, camino por el cual los procesos mentales puedan fluir libremente, sin la intervención de la razón. Atento a esta visión, la cinematografía es la que más se acercaría al funcionamiento de la mente humana tal como describe este funcionamiento Henri Bergson.

El film nos muestra el pasado y el presente, lo visible y lo invisible, lo onírico y lo real y la fusión de todo donde el espectador forma parte de los acontecimientos, él se ve forzado a ser parte de la historia. Es la intención del director la de colocar al público en un ambiente irreal donde hacerlo sentir que es parte de un mundo desconocido y lejano.

Fellini se mantiene fiel a la poética surrealista a través del mundo del inconsciente que muestran sus imágenes. Esta es la propuesta de la acción automática en la asociación de ideas lo que lleva a la experimentación del mundo de los sueños y del mundo real. Como en la pintura surrealista las imágenes del mundo son una expresión de lo mágico contra lo natural. 
Son lugares de presencia fantástica donde la escenografía es la herramienta que prepara el ambiente por el que transcurren los momentos de abstracción de la realidad del mundo, para sumergirnos en tiempos extraños y

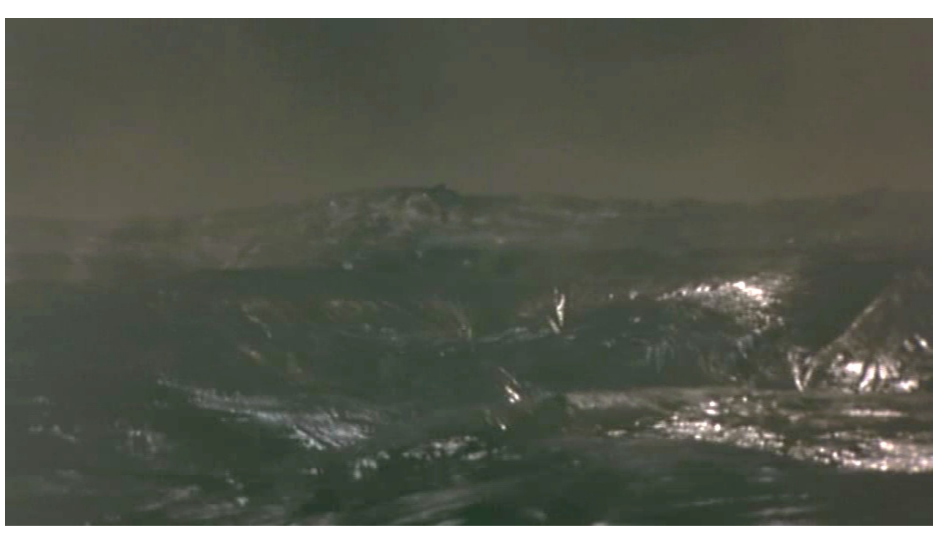

(Fig.19)

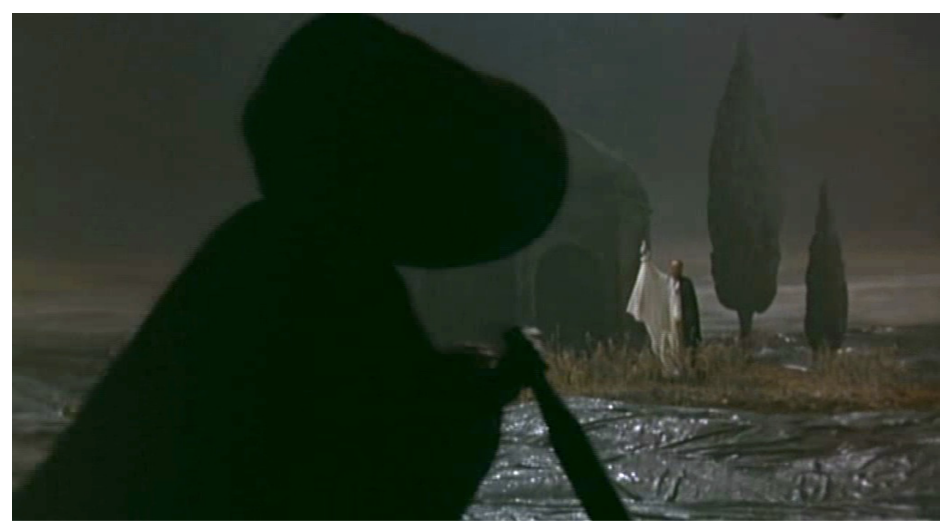

(Fig.20)

lugares ajenos manejados con un cuidado extremadamente calculado y preciso. Y me refiero aquí, por ejemplo, a la factura del mar de plástico (Figs.19 y20). Fellini toma un elemento de la realidad y lo materializa como un elemento teatral que resulta tan falso y tan verosímil que sumerge en un estado fantástico de irrealidad onírica. Este elemento referencial, como tantos otros, se repiten a lo largo de la secuencia cinematográfica haciendo de la totalidad, un viaje surrealista.

Por último, quisiera referirme al color como un recurso de significativa importancia, tal como lo evidencia en cada cuadro de la obra. Este es manipulado como un medio altamente expresivo que no sería posible sin la luz, ya 
que, por así decirlo, la luz y el color son las dos caras de una misma moneda. Pero Fellini, nuevamente, hace de este recurso una obra barroca en lo que hace al despliegue multicolor de algunos escenarios y claramente en el énfasis puesto en el fastuoso vestuario.

\section{Es esta arquitectura donde Nouvel da forma al tiempo. Hecha posible por las civilizaciones desde lo} inmemorial, es la arquitectura la única en hacerlo verdaderamente presente gracias a su capacidad concreta de dilatarlo, prolongarlo, ralentizarlo o extenderlo. Es la arquitectura, cuyo tiempo es construido por la luz; esta luminosidad que no es controlable por nuestros sentidos.

Es una arquitectura presente por la existencia de la luz, capaz de suscitar en el observador la suspensión en el tiempo y provocar la emoción. Emoción que dice que sin ella no hay recuerdo. Y lo hace en varios sentidos. Actúa como un organismo vivo capaz de acompañarnos como un testigo vivo de la experiencia del tiempo. Podría decirse entonces que esta arquitectura se halla inmersa en él, siendo su contenedor y su recipiente más valioso.

No obstante en el Museo del Muelle Branly, la obra no necesita de referencias concretas, sino que cada uno de sus componentes es un relato vivo de esa sucesión de minutos y horas.

Lo anterior, que casi pertenece al orden de lo indecible, y que tiene por lo tanto algo de ambiguo, es fácil de entender por medio de las imágenes que recibo de los objetos: es el lento paso de sol por las aberturas laterales, los puntos luminosos del cielo que me cubre y el dejarse llevar, el observar y sentir lo que hace posible el sentido del lugar. (Fig. 


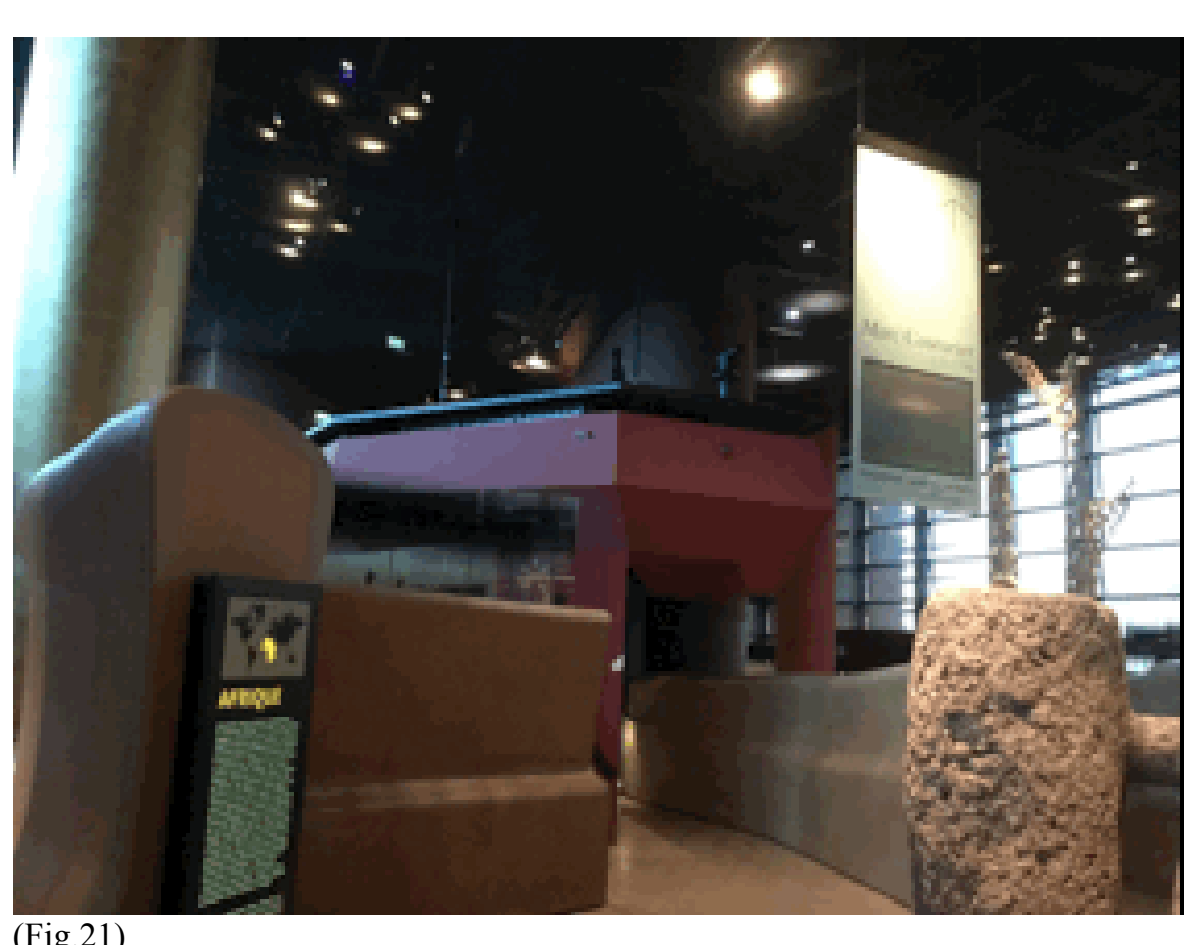

(Fig.21)
Todo hace de esta arquitectura refugio del tiempo, gracias a la habilidad temporal que la obra posee. Es la arquitectura el único lugar eficaz para guardarlo, almacenarlo y enriquecerlo. Joseph Joubert dice, "El tiempo se encuentra de antemano en la eternidad; pero no es el tiempo terreno, el mundano... Ese tiempo no destruye, sólo consuma" (Joseph Joubert, Pensées, París. 1883, Pg. 162).

En el recorrido por el museo se siente el compás que marca la naturaleza,

armonizando los espacios con la luz, caracterizándolos con el paso del sol. Es el tiempo manifestándose en la arquitectura y en sus ramificaciones sorprende observar recuerdos de aquellas culturas que se entremezclan.

En el interior, se observa hacia arriba un vasto cielo negro. Nada separa; nada se interpone entre los visitantes; los vidrios son apenas velos que sostienen los objetos. 
Deambulando bajo la luz artificial que simula un cielo estrellado se puede sentir la serenidad del espacio mientras que da cuenta del exceso de tiempo, del sobrante que resulta de andar sin rumbo fijo, del no detenerme en ningún lugar ni objeto en especial, es quizá el tiempo desperdiciado "perniciosamente infinito" (Boris Groys, 2014).

Es la pérdida de sentido contemplativo a favor del sentido activo del espectador. La arquitectura es el escenario, el entorno, el fondo perfecto para los recuerdos.

Este es el lugar perfecto para el encuentro entre la realidad y la virtualidad de este espacio; suspendo el juicio y me tropiezo con un sinfín de evocaciones que me transportan de un lugar a otro, atravesando por todos aquellos espacios que llenan con su energía. Se siente la libertad de poder "perder el tiempo" entre las cosas allí presentes. Caminando un poco más aparece un pequeño espacio abierto; un brillo produce un deslumbramiento. Poco a poco empieza a desaparecer el exceso de luz y aparece un gran ámbito que, aún contenido, parece escaparse por segundos para colmar a este lugar de una magnífica sensación de grandeza.

La oscuridad termina con la luz que había logrado aparecer. En esta penumbra, cada recuerdo lleva a otro recuerdo; cada historia, cada lugar, provocando diversas emociones y distintas sensaciones.

La experiencia sensible de esta obra provoca emociones diversas, unas de ellas provenientes del contacto directo con la luz en el lugar y otras producidas por lo contenido en el recuerdo que produce ese contacto. Esa experiencia, la emoción del momento deja recuerdos que formarán parte del pasado y alimentarán futuras percepciones de lo real y de lo irreal. La emoción invade y lo que queda es el recuerdo de ese momento. Son imágenes volátiles que formarán parte de un mundo interior que se volverá así, más profundo y más amplio. 


\section{v. SOMBRAS}

Lo bello no es una sustancia en sí, sino un juego de claroscuros producido por la yuxtaposición de las diferentes sustancias que va formando el juego sutil de las modulaciones de la sombra.

Tanizaki, Junichiro. El elogio de la sombra. www.casadellibro.com/ libro-el-elogio-de-la-sombra/9788478442584/469953. Pg.2.

Es difícil imaginar la luz sin su ausencia. Innegablemente, es uno de los elementos más importantes en la arquitectura: la luz y su par, la sombra. La obra de Jean Nouvel permite la existencia de esa "oscuridad" y la luz es la fuente para producirla. Y aunque sus edificios son bien diferentes, la constante en el diseño es la persistencia de la aparición de la transparencia de los elementos de su arquitectura, y por supuesto, la luz y las sombras.

Escribe María Alba Bovisio (caiana.caia.org.ar/resources/uploads/3-pdf/BOVISIO,\%20Maria\%20Alba.pdf, diciembre 2013) respecto del montaje del Museo de Quai Branly: “García Canclini, haciéndose eco de lo planteado por antropólogos como Clifford, Godelier y Descola, entre otros, señala que la exposición presenta una lectura estetizante con una pretensión universalizadora condicionada por la historia colonial francesa, desde la que se decide 
cuáles son obras maestras. El edifico permite una circulación por desfiladeros en penumbras en los que destacan las vitrinas iluminadas donde se encuentran las piezas sin ninguna información, salvo la de los textos que introducen a las salas y unos pocos videos sobre ceremoniales o vida cotidiana de las comunidades: la escasez de explicaciones y sobretodo la penumbra general propone una estetización uniforme".

Para García Canclini, el núcleo del cuestionamiento lo constituye el "universalismo" que se genera desde la sombra o la penumbra en la que se exhiben los objetos. Esta discusión se funda en toda la lectura crítica al occidentalismo que entiende que la colonialidad es el reverso de la modernidad y el "universalismo" es el relato más fuerte de esa "modernidad colonial”, de modo que acusar a la estética del museo de universalizar la presentación de los objetos es como culparlo de re-colonizar esas manifestaciones.

Pero, observemos que en la complejidad de la llamada "modernidad", no es el universalista el único valor en juego ya que, por ejemplo, el Barroco ya problematiza ese valor universal poniendo el acento en lo individual, y esto se da justamente a partir del uso de las sombras y del claroscuro.

Esta crítica a los criterios expositivos y antropológicos, confirma paralelamente y de manera explícita la intención del arquitecto de valerse de los efectos que producen la luz y su consecuencia, la sombra. Queda así probada la intención firme y clara de lograr el clima que nos transporte al lugar donde las culturas "primeras" o "primitivas" se desarrollaron. Y es sin duda la intención de Nouvel la de sumergirnos en esos territorios lejanos y permitirnos la experiencia estética de transitar por ellos. Luces y sombras resaltan así las ricas cualidades de los materiales y de los 
objetos expuestos que permanecen mudos y silenciosos en la penumbra. Se puede sentir la vibración de esta arquitectura a medida que uno avanza a través del espacio del museo, mientras que la luz solar que se filtra a través de la piel del edificio crea un ambiente mágico de sombra. La serie de fenómenos de luz y sombra que se suceden aquí están presentes para que los visitantes del museo se sientan transportados a aquellos territorios de donde provienen los objetos desplegados en el espacio de la gran nave.

Ya que la luz es el principal medio para experimentar la sombra, ésta nos permite verla, apreciar sus formas, diferenciar el carácter de sus espacios y siendo la luz y la sombra dos fenómenos y a la vez una unidad, es que Nouvel proyecta este conjunto considerando los efectos producidos por la incidencia del destello lumínico y su consecuencia en las penumbras que éste crea. Aunque el uso de la sombra es en muchas ocasiones generadora de espacios apacibles es además, en el ámbito del museo, generadora de un clima inquietante y misterioso donde el equilibrio entre luz y penumbra determina la calidad ambiental del espacio. La luz y la sombra son aquí parte principal de esta arquitectura donde desempeñan un papel fundamental en el acto de la percepción de la belleza de la obra y contribuyen además a la definición vibrante de los espacios del museo.

Siendo el sol el recurso más abundante y aprovechable y ya que con su potencial energético se pueden crear diversidad de sensaciones tanto en los espacios interiores como en los exteriores de la obra, es que el arquitecto hace uso de todo su potencial evidenciándose en el tratamiento que le da a los elementos de cerramiento de la piel del edificio tanto como a la disposición de grandes masas arbóreas que conforman el bosque circundante. 
Se disponen perforaciones en los paramentos verticales que cierran el perímetro del edificio para ingresar la luz solar y carece totalmente de iluminación cenital. Se utilizan techos altos y oscuros con iluminación artificial. En el perímetro del edificio se disponen vanos de diferentes dimensiones con elementos de control lumínico según su orientación.

El dominio de la luz y la sombra en el museo es esencial en el diseño de Nouvel. Los efectos de misterio e incertidumbre logrados responden al manejo de los elementos superficiales de la envolvente del edificio, principalmente en sus lados norte y sur donde el gran espacio longitudinal del museo vibra de modo diferente según la incidencia de la luz solar. Es así que la sombra define un espacio temporal.

...y en general, se revela en nuestra alma la existencia de toda una serie de perturbaciones de este tipo y, por esta debilidad de nuestra naturaleza, la pintura de sombras, la prestidigitación y otras muchas invenciones semejantes son aplicadas y ponen por obra todos los recursos de la magia.

Platón, La República, 602d

El frente norte está perforado por 23 cajas de colores que contienen unas pequeñas aberturas ubicadas de acuerdo a las obras que allí se exponen. A su vez, este lateral está compuesto por un enrejado de varillas metálicas revestidos de madera que sujetan 1.500 cristales romboidales. En cada paño hay una película que cumple una doble función: disminuye la intensidad lumínica para conferirle al museo un efecto de bosque tupido y crea en el interior un ambiente de semioscuridad. (Fig.22). Son los paisajes pertenecientes a los orígenes de los objetos expuestos que 
contienen todos estos planos vidriados. Estas imágenes impresas en el material han sido trasladadas a los cristales a partir de fotografías aportadas por el paisajista de los jardines del museo. Empieza por el este con un bosque africano, continúa por la sabana y termina al oeste con bosques de Asia y Oceanía. Esta imagen contrasta con los

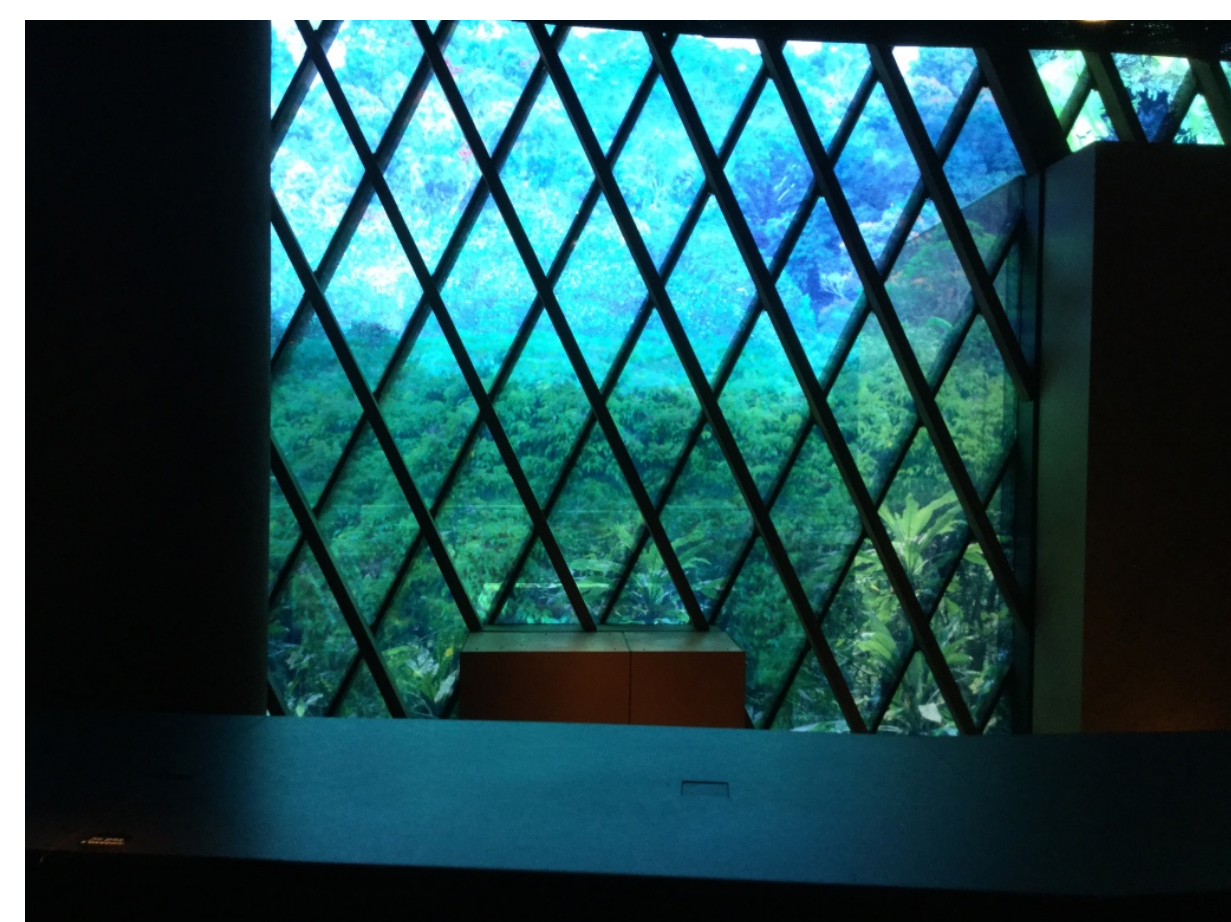

(Fig.22) Los cristales romboidales

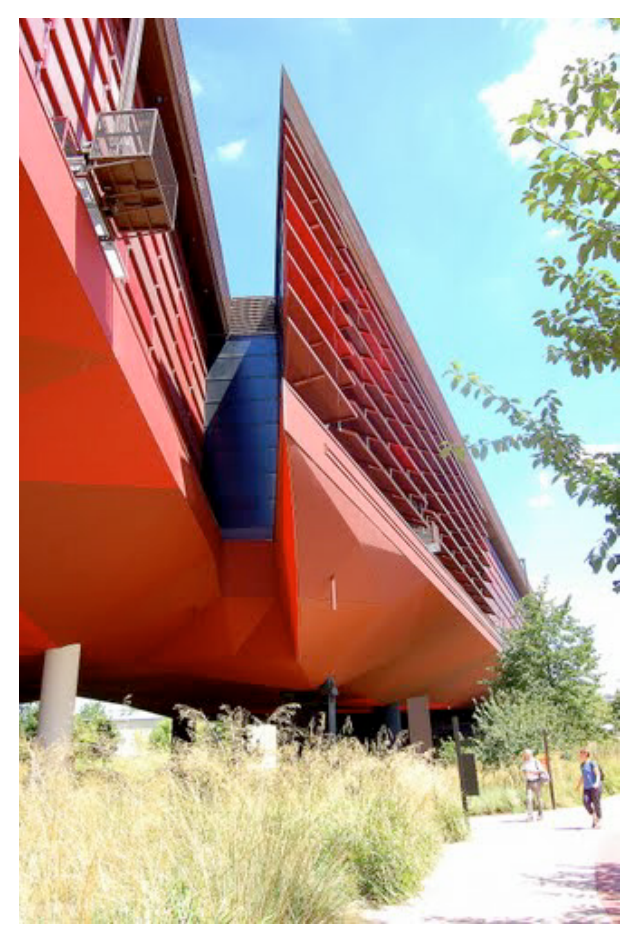

(Fig.23) Vista del frente sur.

árboles del jardín del lado norte, lo que coloca al visitante en un ambiente contradictorio de realidad y ficción.

Por el lado sur (Fig.23), la fachada acristalada de la gran nave longitudinal está protegida por una película serigrafiada de puntos. Este recurso hace que ésta casi desaparezca desde el interior y permite al espectador una vista 
franca hacia el ambiente exterior. Las lamas horizontales metálicas son regulables eléctricamente y se muestran como persianas con sus elementos de control vertical. Estos elementos de regulación lumínica están pintados con un degradado de ocho colores que van del marrón al rojo. Este efecto aparece igualmente por debajo de la fachada del edificio en el plano horizontal de placas poligonales que forman parte del cielorraso bajo la gran sala del museo. Este diseño logrado por Nouvel da la impresión de pasar bajo el vientre de un gran animal. Este gran plano horizontal que conforma el semicubierto del conjunto define a su vez la sexta fachada del edificio. Sobre el lado sur y hacia el oeste, aparece un volumen semicircular. Es el espacio de las exposiciones temporales que se encuentra recubierto en todo su perímetro por tres hileras de paneles que están compuestos por una serie de planos o escamas metálicas blancas. Los cristales de este espacio son perpendiculares a las escamas blancas y permiten de esta manera que la luz no penetre de forma directa sino difusa contribuyendo así al logro de este ambiente tan especial de semioscuridad (Fig. 24). Completando este conjunto, una abertura superior permite encuadrar la vista de la torre Eiffel con la intención de devolver al visitante al paisaje urbano (Fig.25).

La luz sabiamente regulada marca las sombras rotundas que dibujan con fuerza los volúmenes de las obras allí expuestas. Es también un buen medio para la conducción psicológica de la percepción y la acentuación de lo esencial, pues la falta de luz impediría al observador desenvolverse en el entorno de las salas y un exceso de ésta anularía las sombras y con ello, los volúmenes de las formas. De la misma manera, luces perpendiculares a la superficie darían un mínimo de sombras disimulando las imperfecciones de los objetos; en cambio, cuando aparece la luz rasante, las superficies alargan las sombras y acentúan las texturas y los relieves. 
La luz y las sombras son las que permiten distinguir los volúmenes y las formas de la arquitectura y esto es lo que finalmente garantiza nuestra percepción del espacio. Es esta la percepción de un ambiente característico de culturas ajenas y desconocidas, favorecida por un cuidado diseño en el manejo de la luz para producir efectos de

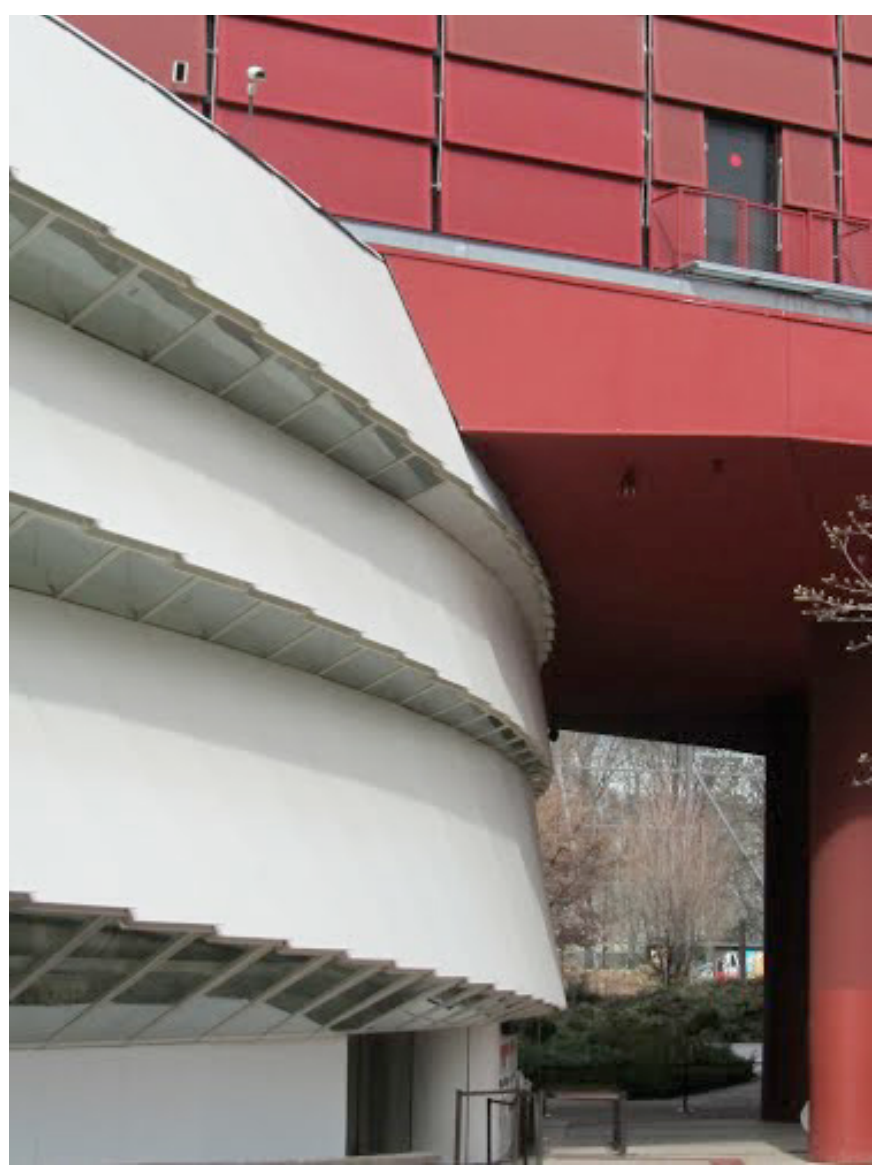

(Fig.24) Las exposiciones temporales y el control lumínico

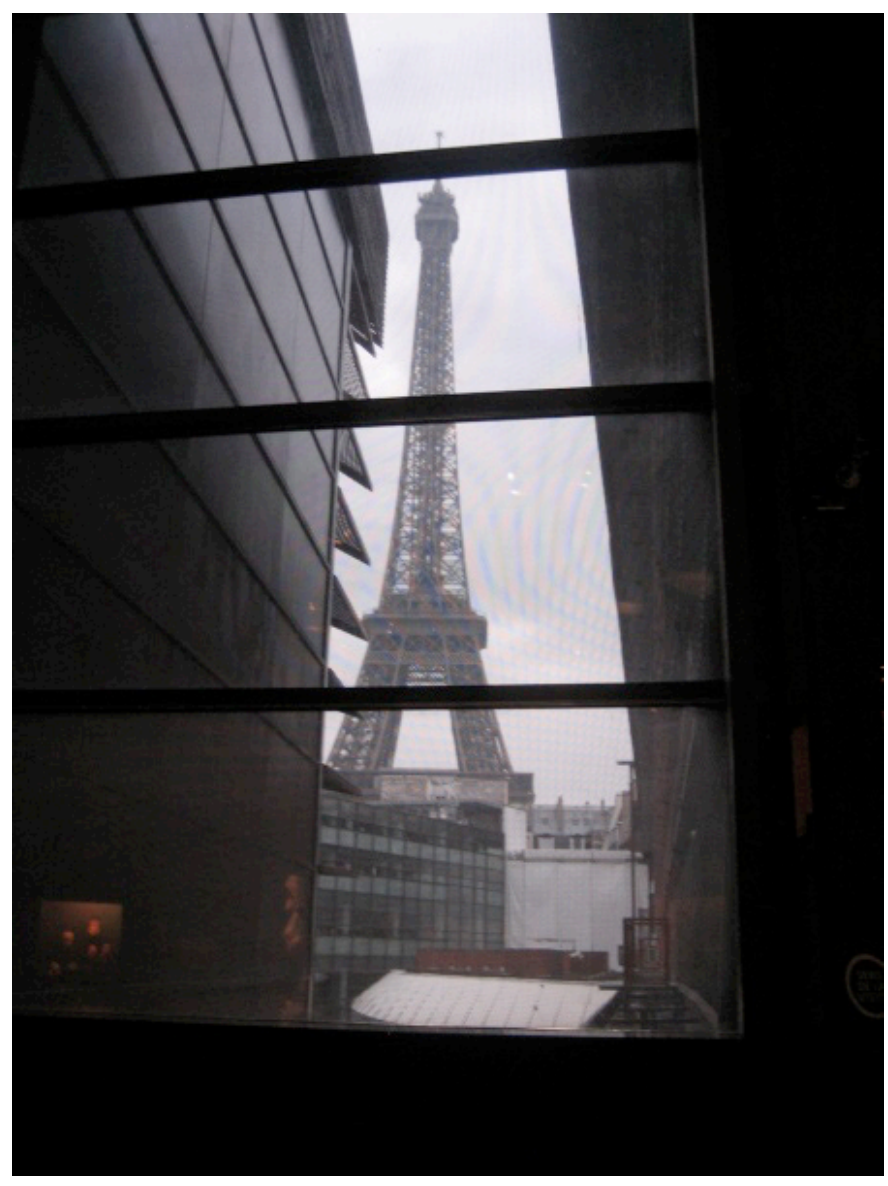

(Fig.25) Vista de la Torre Eiffel 
sombras y semioscuridad. Podría decir entonces, que la penumbra lograda es característica de la presencia de una luz diurna calibrada por los dispositivos dispuestos en la piel del edificio.

Por el contrario, una abundancia de luz en esta "cueva" que es la gran sala de exposición, redundaría en una pérdida de los deseados efectos escenográficos.

La utilización del recurso de la penumbra en la arquitectura contemporánea no es un accidente o falta de control de la luz natural y/o artificial, es realmente una decisión que toma el arquitecto. Este balance entre la luz y penumbra nos dice de la calidad ambiental de un edificio cuando además esta condición es la buscada para lograr efectos específicos como los que Nouvel persigue con el propósito de reforzar el deseado simbolismo en toda la obra.

Hasta hace no mucho tampoco en Occidente conocían la electricidad, el gas o el petróleo pero, que yo sepa nunca han experimentado la tentación de disfrutar con la sombra; desde siempre, los espectros japoneses han carecido de pies; los espectros de Occidente tienen pies, pero en cambio todo su cuerpo, al parecer, es translúcido. Aunque sólo sea por estos detalles, resulta evidente que nuestra propia imaginación se mueve entre tinieblas negras como la laca, mientras que los occidentales atribuyen incluso a sus espectros la limpidez del cristal.

Tanizaki, Junichiro. El elogio de la sombra. www.casadellibro.com/ libro-el-elogio-de-la-sombra/9788478442584/469953. Pg.21.

Estas expresiones ponen de manifiesto que en el museo del Muelle Branly no hay una concepción eminentemente occidental en el tratamiento de las sombras sino por el contrario se advierte que para el arquitecto era esencial considerarlas como un recurso muy presente en los ámbitos de las culturas que representa el edificio y es así 
como la obra se muestra en toda su plenitud.

Esa luz que pretende ser protagonista en las fachadas y en el bosque, no abusa del efecto de las sombras, sino de la sobriedad de las penumbras. La fuerza expresiva de las formas no está puesta solamente en la pureza de los volúmenes, sino en la variedad de las superficies con una gama de grises de notable sensibilidad y valor.

Cuando destaco la luz en esta obra es porque se vuelve protagonista en compañía de la sombra. Esta adecuada combinación de luz y sombra promueve en esta arquitectura, la capacidad de conmover al convocar a la belleza y al silencio. El espíritu de la percepción y la fuerza metafísica de esta arquitectura se deben a la calidad de la luz y la sombra formada por sólidos y vacíos, por opacidades, transparencias y translucidez. La luz natural, con su variedad etérea de cambio, organiza fundamentalmente las intensidades de esta arquitectura.

Silencio a la luz. Luz al silencio. El umbral del cruce es singularidad, es inspiración donde el deseo de expresar encuentra lo posible, es el Santuario del Arte, es el Tesoro de las Sombras (lo material arroja sombras, las sombras pertenecen a la luz).

Zajonk, Arthur. Cita a Louis I.Kahn en Atrapando la luz: historia de la luz y de la mente. Editorial Andrés Bello. 1995. Pg.268.

En toda la obra de Nouvel se reconoce el valor que le confiere a las luces y a las sombras, al espacio interior y al espacio urbano y natural que rodea a cada una de ellas. En este sentido, el arquitecto siempre imagina que pasea 
por la obra vislumbrando planos con luz o con sombra. Es en este aspecto que su pasión por el cine tiene relación con este deambular imaginario y su correlato con los criterios de diseño que definen el par tiempo-imagen.

En un principio los huecos excavados en los muros permitían la entrada de una luz que marcaba fuertemente las sombras y que los arquitectos sabían controlar. No es hasta el siglo XIX, con la arquitectura hecha de vidrio y acero, que ésta se vuelve incontrolable "todo lo inunda", siendo su manejo el que llega a enriquecer la obra cuando se logra comprender la interacción entre ella y el espacio. Es pues, en este sentido, en su relación con la luz, en el que la idea de lo estereotómico y de lo tectónico se llenan de sentido. Por un lado la arquitectura estereotómica incorpora la luz perforando sus muros, busca atraparla en su interior. Por el contrario, una arquitectura tectónica, necesitará protegerse de la luz que la inunda.

La arquitectura estereotómica es aquella donde la masa pesada de los muros es confortadora del espacio interior donde los muros son los soportes que descargan el peso a tierra firme. De esta manera, la captación de la luz solo se hace posible gracias a unas perforaciones en el cerramiento sólido exterior.

Es la arquitectura de piedra y de ladrillo, la arquitectura de arcos, bóvedas y cúpulas allí donde el esfuerzo de los constructores y arquitectos estaba puesto en la cáscara que cerraba y soportaba los esfuerzos de las distintas partes del edificio y no así en el espacio que contenía.

Por otro lado la arquitectura tectónica es aquella que se posa ligeramente mediante soportes aislados independizados de los elementos de cerramiento. Es la arquitectura que debe controlar la luz que la invade por todos sus lados, es la arquitectura que prioriza el espacio interior y su fuerte relación con el exterior situación ésta donde la luz y el espacio 
son los protagonistas de dicha arquitectura.

El protagonismo de la sombra permite que todos los objetos exhibidos en el museo manifiesten su forma y adquieran color y textura. Aquí Las sombras son apropiadamente misteriosas y sugerentes y es la dramatización que los efectos de la luz produce, lo que hace de este espacio el ambiente propicio para unas colecciones que ciertamente pertenecen a unos mundos lejanos, ocultos y quizá incomprensibles. Es la sombra que nos transporta al límite entre lo real y lo imaginario.

El arquitecto lleva el recurso de la sombra no solamente a los espacios expositivos sino también a las zonas públicas de la terraza del edificio donde diseña una cubierta, que luego recrea a una mayor escala en el museo de Louvre de Abu Dhabi en Emiratos Arabes, como una malla irregular que proyecta una suave sombra sobre el espacio interior donde se ubican las mesas del restaurant. Casualmente este espacio gastronómico es 1lamado "Les ombres" o sea "Las sombras".

Al hablar de "arquitectura de sombras”, Etienne-Louis Boullée expresó:

Por mi estado de ánimo particular, la imagen me pareció de una melancolía extrema. Las sombras de los árboles grabadas en la tierra me causaron una profunda impresión. Mi imaginación exageró la escena y, de hecho, vislumbré lo sombrío de la naturaleza. ¿Qué es lo que vi allí? Las masas de los objetos que se erigían en negro, frente a la extrema palidez de la luz. La naturaleza se ofrecía a mi mirada sollozando. Me sorprendieron las sensaciones que estaba 
experimentando y comencé a preguntarme inmediatamente cómo aplicarlas, especialmente a la arquitectura.

Leatherbarrow, David y Mostafavi, Mohsen. La superficie de la arquitectura. Cita en Architecture: Essay on Art en Helen Rosenau, Boullée and visionary architecture. 1976.Pg.106.

Aquí se refería al logro de una arquitectura de melancolía, de ese efecto dramático especial que él buscaba en sus obras. Y no es menos cierto que él mismo se definiera como "inventor de la arquitectura de las sombras y de las tinieblas", lo que lo convierte en un evidente explorador de notables efectos dramáticos en cada una de sus obras.

¿Cuál puede ser el origen de una diferencia tan radical en los gustos? Mirándolo bien, como los orientales intentamos adaptarnos a los límites que nos son impuestos, siempre nos hemos conformado con nuestra condición presente; no experimentamos, por lo tanto, ninguna repulsión hacia lo oscuro; nos resignamos a ello como a algo inevitable: que la luz es pobre, ipues que lo sea!, es más, nos hundimos con deleite en las tinieblas y les encontramos una belleza muy particular.

Tanizaki, Junichirö. El Elogio de la sombra. www.casadellibro.com/ libro-el-elogio-de-la-sombra/9788478442584/469953. Pg.22. 


\title{
v. CONCLUSIÓN
}

\author{
DESCONEXIÓN, PAUSA, PERCEPCIÓN, ASOMBRO, INTUICIÓN ESTÉTICA
}

Las razones de lo bello se separan de las razones del arte. Pero se separan también de las razones que hacen a un objeto ser deseable u odioso. Ahora bien, esta doble negación no define solamente las nuevas condiciones de apreciación de las cosas del arte. Define también una cierta suspensión de las condiciones normales de la experiencia social. Y ello es lo que Kant va a ilustrar, al comienzo de la Crítica del juicio, mediante el ejemplo de ese palacio del que el juicio estético aísla la sola forma, desinteresándose en saber si el palacio sirve a la vanidad de algún noble ocioso y cuánto sudor haya tenido que gastar para construirlo la gente del pueblo. Eso, dice, es precisamente lo que se debe ignorar para apreciar estéticamente la forma del palacio.

Rancière, Jaques. Pensar entre las disciplinas: una estética del conocimiento. https://desarquivo.org/sites/default/files/ ranciere_disciplinas_268.pdf

Husserl hace referencia a la metáfora de la actitud natural. Pero ¿qué significa esta actitud de desconexión, esta "ignorancia"? La filosofía ha reflexionado a menudo sobre este momento. Aristóteles, Descartes, Platón, Kant, casi todos los grandes pensadores también lo han considerado en sus pensamientos. 
Epojé significa desconexión, freno del devenir de los acontecimientos. En sus descripciones de la epojé, Husserl utiliza por lo general, como ejemplos, actos de percepción como actos procuradores de realidad. Entonces, lo que nos queda después de la epojé es un mundo de pura percepción, en el que las cosas en general no pueden ser tenidas en cuenta como instrumentos o cosas que están conectadas en un mundo cultural. La actitud natural no es entonces el modo común del ser humano sino más bien el modo como el científico se planta ante el mundo. Hay que destacar entonces que la epojé es el comienzo de la filosofía y el asombro, el principio del conocimiento. Se trata, entonces, de suspender todo dogmatismo en nuestra actitud hacia la realidad, o sea, poner en práctica la reducción fenomenológica tal como propone Husserl.

La experiencia estética tiene efectivamente la posibilidad de introducir una pausa, una desconexión en el devenir de los acontecimientos para que los objetos sean apreciados como verdaderos objetos estéticos. La experiencia del museo del Muelle Branly parte precisamente de la necesidad de retirarse de la vida ordinaria de la ciudad para poder observar y ser protagonista la obra en toda su riqueza. A través de esta experiencia debe inhibirse, y sostenerse, el contexto de significación que les da sentido a los objetos. Decía Ilya Prigogine (1993): “... inteligencia industriosa del hombre que entiende la naturaleza a través de su doble papel de legislador y experimentador, pero que deja escapar un dinamismo creador que solo la intuición estética es capaz de experimentar”. (¿Tan solo una ilusión?” capítulo “Una exploración del caos al orden”. Naturaleza y creatividad. Tusquets Editores, Metatemas 3. Barcelona. 1993). 
En la experiencia estética de la luz, el color no se puede explicar. Este existe por si mismo. Aquí comienza un saber profundo y verdadero. Se trata de develar el misterio de la percepción y el misterio de la razón. Por este motivo es que sería adecuado ver al color reducido a su mínima expresión. Es la suspensión del juicio. Es el momento del método fenomenológico, la conexión con la esencia, como lo haría Husserl.

Dado que el espacio del museo es una realidad ambigua, es lícito pensar que es un lugar donde lo real y lo imaginario son la misma cosa ya que todos los aspectos sensoriales se confunden, pero a su vez le otorgan a la obra su carácter único e irrepetible. Comparto entonces la idea de Gombrich cuando dice que nuestra percepción es lo único que está en juego, la realidad física queda afuera. Nuevamente es nuestra percepción la que determina el grado de ilusión visual de los objetos que están allí a la espera de ser observados creando un nuevo mundo en nuestro interior que suma recuerdos y es en definitiva ese otro cuerpo que señala Merleau Ponty: otro cuerpo con un saber anterior.

Jean Nouvel concibe y diseña el espacio para que se exprese poéticamente con la luz y lo construye para que mantenga su existencia en una convivencia armoniosa con ella. Es la luz, creadora del espacio mismo, provocadora de emociones, inductora de sentimientos, motivadora de pensamientos y recuerdos para que ella y el tiempo encuentren su sentido en lo que no se puede tocar, pero que se puede sentir.

Efectivamente, la percepción es lo que está en juego. Es la percepción que da sentido a la experiencia; emociona ser parte de esta variedad de espacios que remontan a otra dimensión, a situaciones tal vez pasadas; todos ellos cobrando sentido por la luz y por el tiempo. Mañana será recuerdo. Hoy son momentos, hechos, lugares, 
atmósferas y vivencias que traen nostalgias. El camino por este nuevo mundo, dentro del mundo real de la ciudad, permite que la emoción sea protagonista, y así, el disfrute del presente se suma a la evocación de momentos pasados que sorprendentemente se suman a este aquí y ahora de la experiencia de la arquitectura. Es el nuevo presente que destierra el anterior al pasado y que forma parte del porvenir. Es el tiempo como flujo, como experiencia que queda y encuentra su lugar en la conciencia de lo inmanente y lo trascendente.

Lo que queda lo fundan los poetas, no tanto como "lo que dura" sino ante todo como "lo que queda": huella, recuerdo, monumento.

Heidegger, Martin. De la esencia de la verdad, conferencia dictada en el año 1930.

La experiencia estética en particular debe ocupar un lugar en esta transformación de la vida cotidiana, considerando que posee una competencia única para organizar la fantasía, las emociones y la sensualidad contra la desublimación represiva que ha sido tan característica de la cultura capitalista desde los años sesenta.

Huyssen, Andreas. Después de la gran división. Cap.1. VII. La dialéctica oculta: vanguardia-tecnología-cultura de masas.

Ediciones Adriana Hidalgo. 2002. Pg.40.

Quizá esta partida sea la indicada para la deseada experiencia estética del arte y la arquitectura. 


\section{vI. REFERENCIAS BIBLIOGRÁFICAS}

VII.I. GENERALES

BAUDRILLARD, Jean., (1978), Cultura y simulacro. Editorial Kairos. Barcelona.

(1984), Las estrategias fatales. Editorial Anagrama. Barcelona.

BERGSON, Henri., (1999), Ensayo sobre los datos inmediatos de la conciencia. Ediciones Sígueme.

BLANCHOT, Maurice., (1991), El libro que vendrá. (capítulo: El encuentro con lo imaginario). Monte Avila Editores. Caracas.

BORGES, Jorge Luis., (2002), Los tigres azules, (relato en: La memoria de Shakespeare). Editorial Alianza. Buenos Aires.

CARROLL, Lewis., (1978), Al otro lado del espejo. Editorial Alianza. Buenos Aires.

DE SANTO, Edgar., (2014), ¿Cómo se expresa lo indecible? Hacia una operatoria teórico-ensayística del arte. Tesis doctoral. Recuperado de https://unlp.academia.edu/EdgarDeSanto.

ECO, Umberto., (2011), Arte y belleza en la estética medieval. Editorial DEBOLSILLO.

GADAMER, Hans-Georg., (1996), La actualidad de lo bello. Editorial Paidós. Barcelona.

GÖETHE, Johann Wolfgang., (2013), Teoría de los colores. Editorial Trotta. Barcelona.

GROYS, Boris., (2014), Volverse público. Las transformaciones del arte en el ágora contemporánea. Caja Negra Editora. Buenos Aires. 
GRUPO FLUX., (1985), Motion Design. Recuperado de: https://vimeo.com/csisman

HUYSSEN, Andreas., (2002). Después de la gran división (capítulo: La dialéctica oculta: vanguardia-tecnologíacultura de masas). Ediciones Adriana Hidalgo. Buenos Aires.

KAUFMANN, Emil., (1980), Tres arquitectos revolucionarios: Boullée, Ledoux y Lequeu. Editorial Gustavo Gilli, S.A. Barcelona.

KRAUSS, Rosalind E., (1996), La originalidad de la vanguardia y otros mitos modernos (capítulo: La originalidad de la vanguardia). Alianza Forma. Madrid.

KOYRÉ, Alexandre., (2007), Estudios de historia del pensamiento científico (capítulo: Actitud estética y pensamiento cientifico). Pp.260-273. Editorial Siglo XXI. Madrid.

JUNG, Carl., (1995), El hombre y sus simbolos. Editorial Paidós. Barcelona.

KOVADLOFF, Santiago., (2002), La construcción de la forma en el ensayo. SEmA Seminarios de Primavera. Recuperado de: www.sema.org.ar/downloads/SKovadloff.pdf

MITCHELL, W.J.T. (2003), Mostrando el ver: una critica de la cultura visual. Recuperado de www.estudiosvisuales.net/revista/pdf/num1/mitchell.pdf .

MORIN, Edgar., (1990), Introducción al pensamiento complejo. Pp.21-23. Editorial Gedisa. Barcelona.

PRIGOGINE, Ilya y STENGERS, Isabelle., (1993), ¿Tan solo una ilusión? Una exploración del caos al orden (capítulo: Naturaleza y creatividad). Tusquets Editores. Barcelona.

RANCIÈRE, Jaques., (2008), Pensar entre las disciplinas: una estética del conocimiento. Recuperado de: https://desarquivo.org/sites/default/files/ranciere disciplinas. 
SAN MARTÍN, Javier., (2002), Epojé y ensimismamiento. Conferencia dictada en República Checa. Recuperado de: https:// SAN+MARTÍN,+Javier.+"Epojé+y+ensimismamiento".

SCARTEZZINI, Ricardo y FEYERABEND, Paul., (1996). Universalidad y diferencia (capítulos 1,2 y 10). Editorial Alianza Universidad. Madrid.

SCHOPENHAUER, Arthur., (2013), Sobre la visión y los colores. Editorial Trotta. Madrid.

SIMONDON, Gilbert., (2012), Curso sobre la percepción. Editorial Cactus. Buenos Aires.

STOICHITA, Victor., (1999), Breve historia de la sombra. Editorial Siruela. Madrid

TANIZAKI, Junichirö., (2017), El Elogio de la sombra. Recuperado de: https://www.casadellibro.com/libro-elelogio-de-la-sombra/9788478442584/469953

TOMAS, Héctor., (1998), El lenguaje de la arquitectura moderna. Soluciones Gráficas McPrint. La Plata.

TROVATO, Graziella., (2007), Des-velos: autonomía de la envolvente en la arquitectura contemporánea. Ediciones Akal. Madrid.

TUDELA, Fernando., (1985), Conocimiento y diseño (capítulo VI: La alternativa Popper: donde los diseñadores aprenden a conjugar el verbo 'falsar' y capítulo VI Patrones de descubrimiento: donde la observación pierde su virginidad). Universidad Autónoma Metropolitana. Xochimilco. México.

VAN de VEN, Cornelis., (1981), El espacio en Arquitectura. Ediciones Cátedra S.A. Madrid. 
VOLLENWEIDER, Camila., (2011), Reseña de: Decisiones instintivas. La inteligencia del inconsciente de Gerd Gigerenzer. Reis. Revista Española de Investigaciones Sociológicas, núm. 136, octubre-diciembre 2011, pp. 164-168. Centro de Investigaciones Sociológicas. España.

WITTGENSTEIN, Ludwig., (2013), Observaciones sobre los colores. Editorial Paidós. Barcelona.

ZAJONK, Arthur., (1995). Atrapando la luz: historia de la luz y de la mente. Editorial Andrés Bello. Buenos Aires.

ZÁTONYI, Marta y otros., (2002), ¿Realidad virtual? Ediciones GeKa. Buenos Aires.

ZEVI, Bruno., (1998), Saber ver la arquitectura. Editorial Apóstrofe. Barcelona.

VII.II. ESPECÍFICAS

ALONSO FERNÁNDEZ, Luis., (1999), Introducción a la nueva museología (capítulo 2: Metodología de una ciencia humana y social y capítulo 4: El museo actual y la nueva museología. Alianza Editorial. Madrid.

BAUDRILLARD, Jean y NOUVEL, Jean., (2002), Los objetos singulares. Arquitectura y Filosofía. Editorial Fondo de Cultura Económica de Argentina S.A. Buenos Aires.

CAIVANO, José Luis., (1998), Ilusiones y efectos visuales que involucran distribución espacial de la luz. Actas del Cuarto Congreso Argentino del Color. Editadas por José Luis Caivano y Rodrigo Hugo Amuchástegui. Buenos Aires.

CAMPO BAEZA, Alberto (s.f.)., En torno a la luz y la arquitectura. Recuperado de: www.faud.unsj.edu.ar/ descargas/LECTURAS/Arquitectura/EXTRA/4.pdf

(1992), El blanco certero. Revista Baumeister. Alemania. 
DELEUZE, Gilles., (1994), La lógica del sentido. Segunda serie de paradojas. De los efectos de superficie. Pp.28-34. Editorial Planeta-Agostini. Barcelona.

DEMEUDE, Hugues., (2006), The Musée du Quai Branly. Art Spaces. Editions Scala. París.

GIEDION, Sigfried., (2009), Espacio, tiempo y arquitectura. Editorial Reverté. Barcelona.

HOLL, Steven., (2003), El método de Leonardo citado en revista "El Croquis" Pps.78, 93, 108. Editorial El Croquis.

HUSSERL, Edmund., (1982), La idea de la fenomenología. Fondo de Cultura Económica. México.

KAHN, Louis I., (1980), Louis I. Kahn. Editorial Gustavo Gilli, S.A. Barcelona.

JEANNERET-GRIS, Charles Edouard (Le Corbusier)., (1964), Hacia una arquitectura. Editorial Poseidón.

LEATHERBARROW, David y MOSTAFAVI, Mohsen., (2007). La superficie de la arquitectura.

Ediciones Akal. Madrid.

MONTANER, Josep María., (1986), Los Museos de la última generación. Editorial Gustavo Gilli. Barcelona. (1990), Nuevos museos. Espacios para el arte y la cultura. Editorial Gustavo Gilli. Barcelona.

(1995), Museos para el nuevo siglo. Editorial Gustavo Gilli. Barcelona.

(1997), La modernidad superada (capítulos: Arquitectura y mímesis: la modernidad superada) $\mathrm{y}$

Modernidad, vanguardias y neovanguardias. Editorial Gustavo Gilli. Barcelona. 
MERLEAU-PONTY, Maurice., (1993), Fenomenología de la percepción. Editorial Planeta-De Agostini, S.A. Barcelona.

$$
\text { (2010), Lo visible y lo invisible. Ediciones Nueva Visión. Buenos Aires. }
$$

PALLASMAA, Juhani., (1978), Los ojos de la piel: la arquitectura y los sentidos. Editorial Gustavo Gilli. Barcelona.

PEDRÓS FERNÁNDEZ, Óscar., (2013), Arquitectura e ilusión : las nueve categorías mágicas del espacio. Tesis doctoral. Departamento de Proyectos Arquitectónicos y Urbanismo. Universidad de La Coruña. España. Recuperado de: https://www.google.com/?client=safari\#q=PEDRÓS+FERNÁNDEZ,+Óscar.

+(2013)+“Arquitectura+e+ilusión+:+las+nueve+categor\%C3\%ADas+mágicas+del+espacio”.+Tesis+doctoral.

RINALDI, Mauricio (s.f.)., ¿Qué es la estética de la luz?

Recuperado de: https:// RINALDI,+Mauricio.+“¿Qué+es+la+estética+de+la+luz\%3F”

ROWE, Colin y SLUTZKY, Robert., (1978), Manierismo y arquitectura moderna y otros ensayos (capítulo: Transparencia: literal y fenomenal). Editorial Gustavo Gilli. Barcelona.

SOLÁ-MORALES, Ignasi., (2002), Territorios (capítulos: arquitectura líquida y arquitectura inmaterial). Editorial Gustavo Gilli. S.A. Barcelona.

(1998), Diferencias. Topografía de la arquitectura contemporánea.

Editorial Gustavo Gilli. S.A. Barcelona.

TORRES, Elías., (2004), Zenital light. Pp.96-97. Editorial Colegio de Arquitectos de Catalunya. Barcelona. 
URBANO GUTIÉRREZ, Rosa., (2014), El vidrio y la luz en la envolvente contemporánea.

Tesis doctoral. Universidad Politécnica de Madrid. Escuela Técnica Superior de Arquitectura de Madrid.

Recuperado de: https://www.google.com/?client=safari\#q=URBANO+GUTIÉRREZ,

+Rosa+El+vidrio+y+la+luz+en+la+envolvente+contemporánea+Tesis+doctoral.

ZIZEK, Szlavoj., (2000), Mirando al sesgo. Desde la realidad a lo real. Pp.17-43. Editorial Paidós. Barcelona.

\section{VII.III. METODOLÓGICAS}

BOURDieU, Pierre, PASSERON, J.C., CHAMBOREDON, J.C., (1994), Epistemología y Metodología en El oficio del sociólogo. Editorial Siglo XXI. Madrid.

ECO, Umberto., (2001), Cómo se hace una tesis: Técnicas y procedimientos de estudio, investigación y escritura. 6a.Edición. Editorial Gedisa. Barcelona.

SAMAJA, Juan Alfonso., (2004), Epistemología y metodología. 3ra.Edición. Editorial Universitaria de Buenos Aires. 